CAIO MÁRCIO DE BRITO ÁVILA

\title{
RECALL - A REVOGAÇÃO DO MANDATO POLÍTICO PELOS ELEITORES: UMA PROPOSTA PARA O SISTEMA JURÍDICO BRASILEIRO
}

Tese apresentada à Banca Examinadora da Faculdade de Direito da Universidade de São Paulo, como exigência parcial para a obtenção do título de Doutor em Direito do Estado, sob a orientação do Professor Dalmo de Abreu Dallari

FACULDADE DE DIREITO DA USP

SÃO PAULO

2009 
Banca Examinadora

Prof. Dalmo de Abreu Dallari (orientador) 


\section{Dedicatória}

Aos meus queridos filhos Pedro e Antonio, alegrias da minha vida.

À minha esposa Gilda, pela compreensão e carinho de sempre.

À minha saudosa mãe Anita, pelo exemplo de mulher que foi em vida.

Ao meu pai Urbano, pelo apoio incondicional.

Ao meu sogro Dr. Magalhães e à minha sogra Dona Penha, pelo incentivo contínuo. 
Agradecimentos

Minhas sinceras homenagens e agradecimentos ao Professor Dalmo de Abreu Dallari, símbolo de resistência e luta pela consolidação dos valores democráticos na sociedade brasileira 


\section{RESUMO}

Trata a presente tese de estudo acerca do instituto denominado recall, existente nos Estados Unidos da América do Norte, que constitui mecanismo que permite a destituição de autoridades públicas e a revogação de decisões judiciais, por meio de decisão popular.

O ineditismo da tese decorre do aprofundamento que se fez sobre o tema, bem como da análise minuciosa sobre as condições de aplicação desse instituto no Brasil.

Para compreensão integral do objeto em análise, inicialmente, buscou-se compreender o fenômeno da representação política, não só sob o aspecto jurídico-formal como também pelo aspecto histórico, político e social. As teorias acerca da representação política são abordadas dentro de uma perspectiva evolutiva, histórica, desde os seus traços primitivos nas sociedades antigas, passando pelas instruções e mandato imperativo do período medieval, até as concepções de Hobbes, Locke, Burke e Siéyès, não deixando de lado as posições mais modernas e os dilemas existentes sobre o tema.

Busca-se também a essência desse mecanismo denominado recall. Para tanto, torna-se obrigatória a passagem pelas suas origens e pela sua configuração jurídica, que se encontra relacionada com o princípio federativo, os sistemas eleitorais, sua caracterização como direito político, instituto de democracia participativa e semidireta, bem como seu caráter sancionador e como forma de expressão da oposição política.

Faz-se, além disso, uma análise comparativa do recall no direito contemporâneo. Inicialmente focando o instituto nos Estados Unidos da América do Norte, pelo âmbito de aplicação do instituto na Federação norte-americana, as hipóteses e procedimentos de cada Estadomembro (onde se permite o instituto) e os resultados gerais de sua aplicação. Analisar-se-á, outrossim, institutos semelhantes ao recall existentes em outros sistemas jurídicos.

Ao final, será tratada a questão relacionada ao recall e o sistema jurídico brasileiro, apresentando-se a história da revogação do mandato político no país, o panorama jurídico pelo aspecto federativo e dos sistemas eleitorais, bem como as condições para viabilizar a aplicação do instituto no Brasil. Tudo isso, para se demonstrar que o recall deve ser um mecanismo democrático a ser utilizado por eleitores responsáveis contra eleitos irresponsáveis.

Palavras-chave: RECALL - REVOGAÇÃO - MANDATO - MANDATO POLÍTICO REPRESENTAÇÃO POLÍTICA - PARTICIPAÇÃO POPULAR DEMOCRACIA SEMIDIRETA - DEMOCRACIA PARTICIPATIVA MECANISMO DE CONTROLE POLÍTICO - DIREITO POLÍTICO 


\section{ABSTRACT}

This dissertation focuses on the mechanism referred to as recall, which exists in the United States of America, and is a mechanism that provides for the removal of public officials and the repeal of judicial decisions by means of public opinion.

The originality of this dissertation arises out of the further understanding of the subject, as well as of the thorough analysis of the conditions under which such mechanism could be applied in Brazil.

In order to fully understand the analyzed object, it was first necessary to understand the phenomenon of political representation, not only from the formal-legal aspect, but also from the historical, political and social perspectives. The theories on political representation are approached from a historical-developing standpoint, from its primitive traces in ancient societies, to the medieval instruments and imperative mandate, to the ideas of Hobbes, Locke, Burke and Siéyès, in addition to the more modern schools of thought and existing dilemmas on the subject-matter.

The dissertation also focuses on the essence of the recall mechanism. In order to do so, it was necessary to examine its origins and its legal configuration, which has to do with the federative principle, the electoral systems, its characterization as public law, participatory and semi-direct democracy, as well as its sanctioning ability and political opposition form of expression.

Furthermore, the comparative analysis of recall in contemporary law is also carried out. The assessment is initially focused on the mechanism in the United States of America, as per its application in the North American Federation, the hypotheses and procedures of each MemberState (in which the mechanism is provided for) and the general results of its application. Moreover, similar mechanisms available in other legal systems are also analyzed.

Finally, the issue of the recall mechanism and the Brazilian legal system is assessed, through the history of the repeal of political mandates in the country, its legal framework on the federative aspect and the electoral systems, as well as the conditions necessary in order to render the application of the recall mechanism in Brazil feasible. The objective is to demonstrate that the recall mechanism should be a democratic mechanism to be used by responsible voters against irresponsible elected officials.

Keywords: RECALL - REVOCATION - MANDATE - PUBLIC MANDATE - TERM OF OFFICE - POLITICAL REPRESENTATION - CITIZEN PARTICIPATION DIRECT DEMOCRACY - PARTICIPATORY DEMOCRACY - POLITICAL CONTROL DEVICE - POLITICAL RIGHT 


\section{RÉSUMÉ}

La présente thèse aborde l'étude de l'Institut appelé Recall, existant aux Etats-Unis de l'Amérique du Nord et qui constitue un mécanisme permettant de destituer des autorités publiques et de révoquer des décisions judiciaires, à travers la décision populaire.

Le caractère inédit de la thèse découle de l'approfondissement fait à propos du thème, aussi bien que de l'analyse minutieuse des conditions d'application de cet institut au Brésil.

Pour la compréhension intégrale de l'objet analysé, l'on a cherché initialement à comprendre le phénomène de la représentation politique, non seulement sous l'aspect juridique et formel, mais aussi sous les aspects historique, politique et social. Les théories à propos de la représentation politique seront abordées dans une perspective évolutive, historique, depuis leurs traits primitifs dans les sociétés anciennes, en passant par les instructions et le mandat impératif de la période médiévale, jusqu'aux conceptions de Hobbes, Locke, Burke et Siéyès, sans laisser de côté les positions plus modernes et les dilemmes existants sur le thème.

On cherche également l'essence de ce mécanisme nommé recall. Pour ce faire, il est obligatoire de passer par ses origines et par sa configuration juridique, qui est liée au principe fédératif, aux systèmes électoraux, à sa caractérisation en tant que droit politique, à l'institut de démocratie participative et semi-directe, aussi bien qu'à son caractère de celui qui sanctionne et en tant que forme d'expression de l'opposition politique.

En outre, on fait une analyse comparative du recall dans le droit contemporain en focalisant d'abord l'institut aux Etats Unis de l'Amérique du Nord, dans le cadre d'application de l'institut dans la Fédération nord-américaine, les hypothèses et les procédures de chaque Etatmembre et les résultats de son application. On analysera également des instituts similaires au recall qui existent dans d'autres systèmes juridiques.

Finalement, la question liée au recall et au système juridique brésilien sera traitée, à travers la présentation de l'histoire de la révocation du mandat politique dans le pays, le panorama juridique par l'aspect fédératif des systèmes électoraux, aussi bien que les conditions pour rendre viable l'application de l'institut au Brésil. Tout cela pour démontrer que le recall doit être un mécanisme démocratique à utiliser par des électeurs responsables contre des élus irresponsables.

$\begin{array}{ll}\text { Mots-clés: } & \text { RECALL }- \text { RÉVOCATION }- \text { MANDAT }- \text { MANDAT POLITIQUE }- \\ & \text { REPRÉSENTATION POLITIQUE }- \text { PARTICIPATION POPULAIRE }- \\ & \text { DÉMOCRATIE SEMI-DIRECTE }- \text { DÉMOCRATIE PARTICIPATIVE }- \\ & \text { MÉCANISME DE CONTRÔLE POLITIQUE - DROIT POLITIQUE }\end{array}$




\section{SUMÁRIO}

\section{A REPRESENTAÇÃO POLÍTICA}

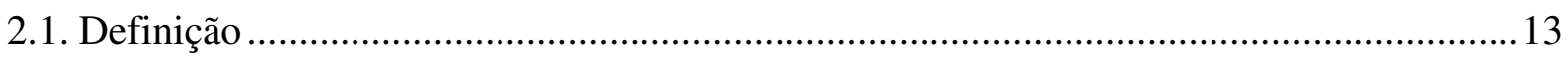

2.2. A Evolução Histórica da Representação Política ............................................................. 16

2.2.1. Formas de representação na Antiguidade .............................................................. 16

2.2.2. A Representação Política na Idade Média ............................................................... 19

2.2.2.1. As raízes da representação política........................................................... 19

2.2.2.2. A teoria do mandato imperativo ............................................................... 21

2.2.3. A Formação do governo representativo na Inglaterra e as noções sobre representação dos pensadores ingleses .................................................................2 23

2.2.3.1. O contexto histórico e social da formação do governo representativo.......23

2.2.3.2. Thomas Hobbes. A representação no sentido de autoridade ....................... 25

2.2.3.3. A Revolução Gloriosa e o Poder Legislativo de John Locke ......................26

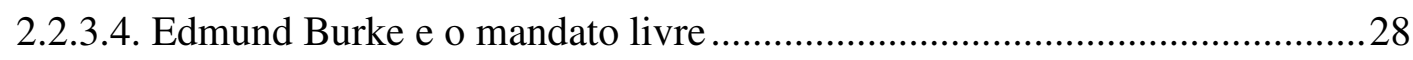

2.2.4. A representação política na França do Século XVIII ............................................. 30

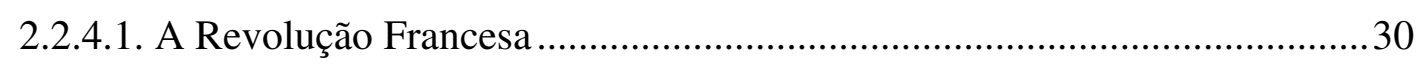

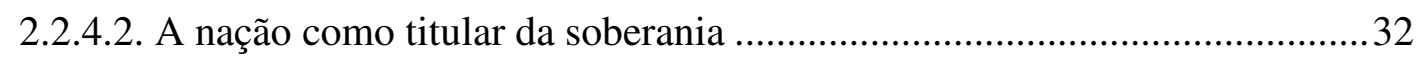

2.2.4.3. A teoria do mandato representativo e a teoria da duplicidade.................... 35

2.2.5. A representação política nos Estados Unidos ........................................................ 36

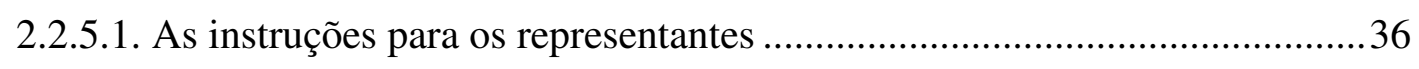

2.2.5.2. O governo representativo norte-americano ............................................... 37

2.2.6. A representação política no Século XIX ................................................................... 39

2.2.6.1. Os questionamentos sobre a representação política ...................................39

2.2.6.2. A teoria dos órgãos ............................................................................ 40

2.2.6.3. O governo representativo de Stuart Mill .................................................. 40

2.2.6.4. A ampliação do direito de sufrágio.......................................................... 41

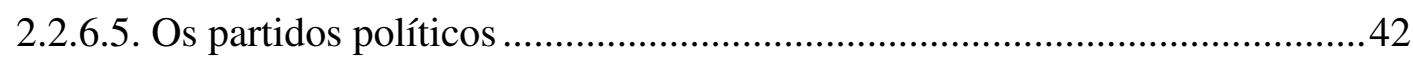

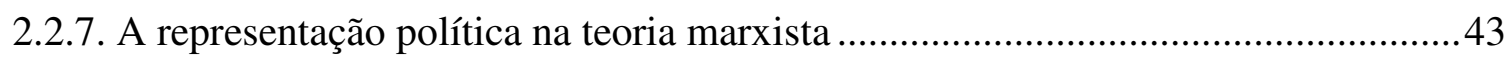

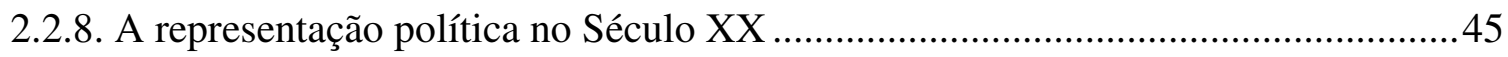

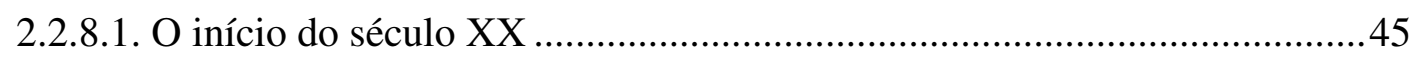

2.2.8.2. A crítica de Hans Kelsen sobre a representação política.............................46

2.2.8.3. Outras teorias sobre a representação política ............................................. 47

2.2.9. A representação política dentro de uma nova perspectiva social e política.............49 


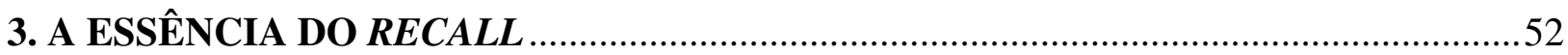

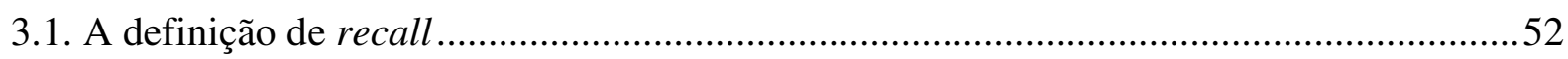

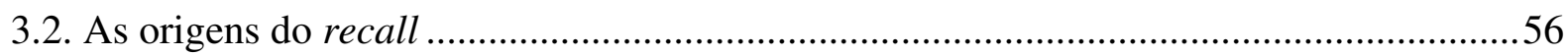

3.2.1. A perda de função pública por decisão popular no passado remoto ...........................56

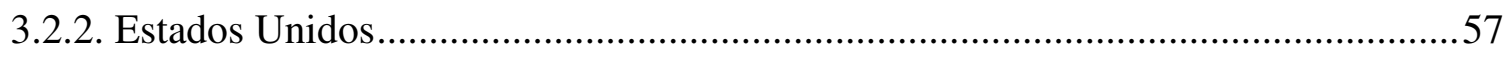

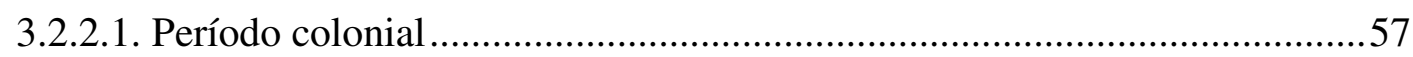

3.2.2.2. A revogação de mandatos nos Artigos da Confederação e nas Convenções de Ratificação .59

3.2.2.3. A destituição das autoridades públicas e a revogação das ordens judiciais por decisão popular. $\mathrm{O}$ instrumento progressista denominado

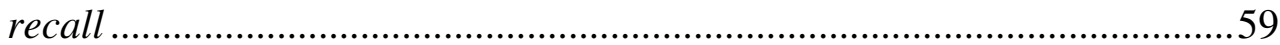

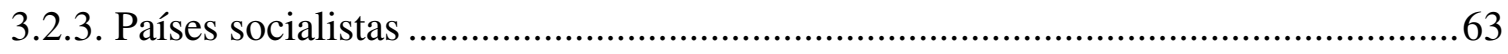

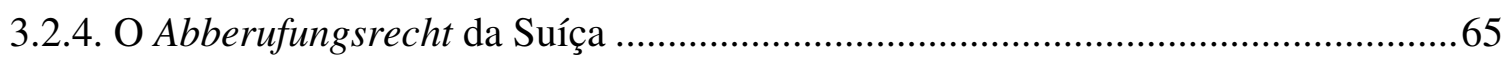

3.2.5. O mecanismo da Constituição de Weimar..................................................................66

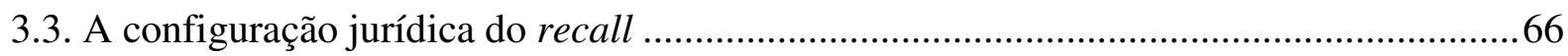

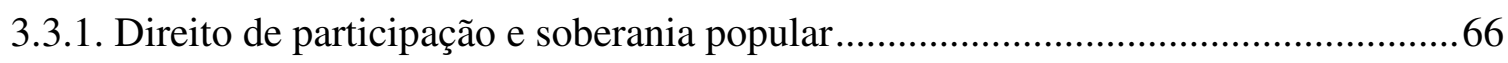

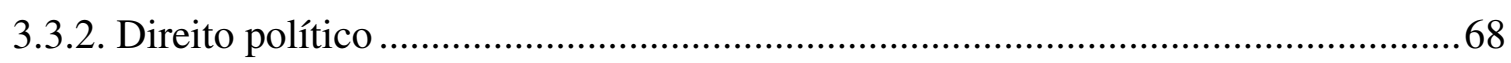

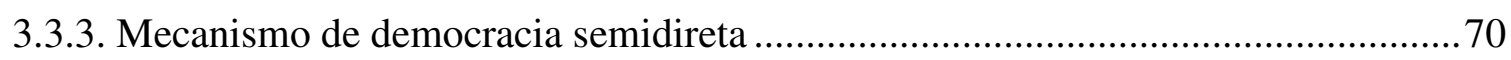

3.3.4. Instrumento da democracia participativa ..............................................................71

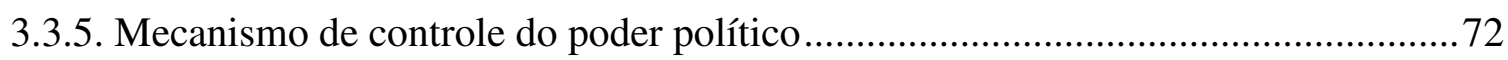

3.3.6. Forma de expressão da oposição política................................................................

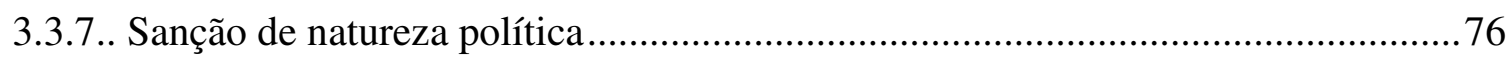

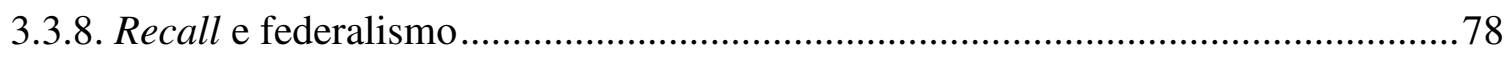

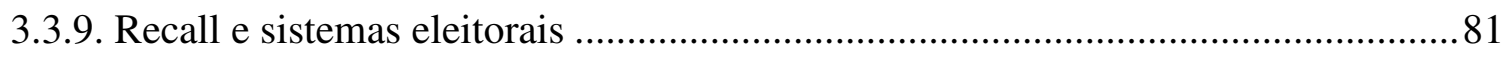

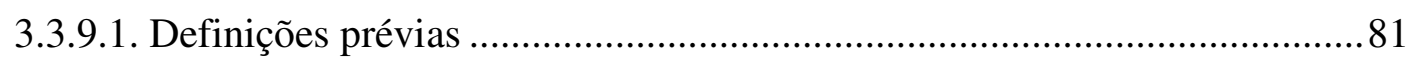

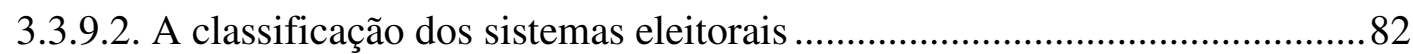

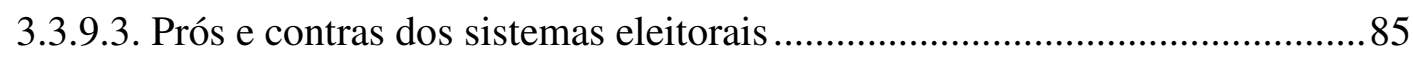

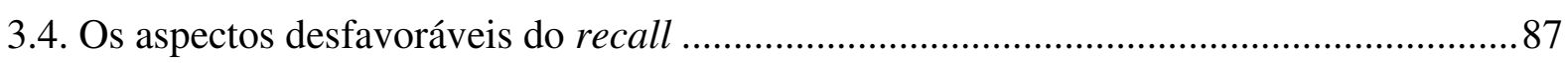

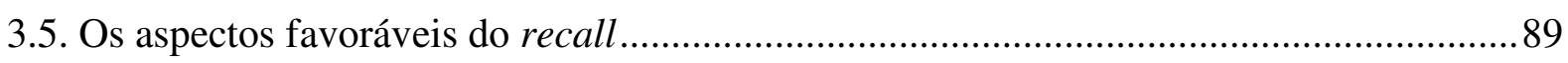

4. ANÁLISE COMPARATIVA DO RECALL NO DIREITO CONTEMPORÂNEO_........93

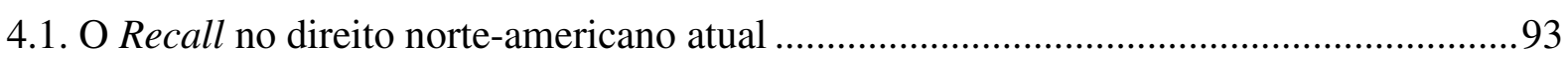

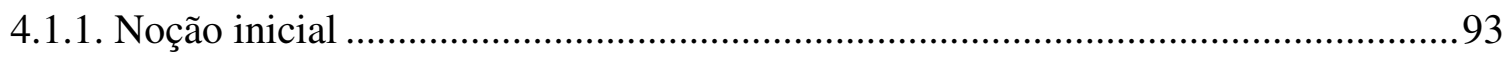

4.1.2. Âmbito de aplicação do instituto na federação norte-americana .............................93

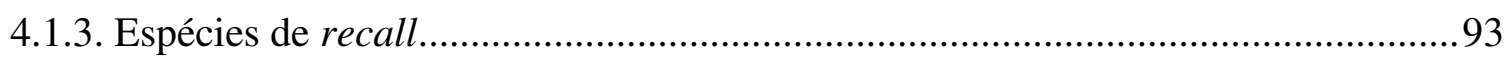

4.1.4. Recall nos estados-membros americanos: hipóteses e procedimentos ....................95

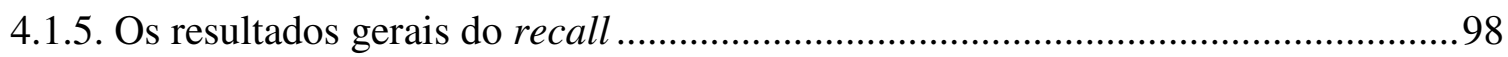

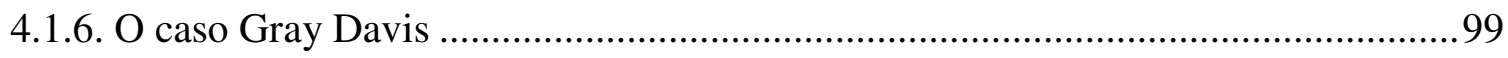


4.2. Instrumentos semelhantes ao recall em outros sistemas jurídicos ................................ 101

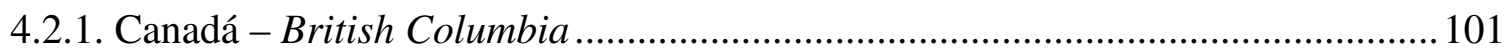

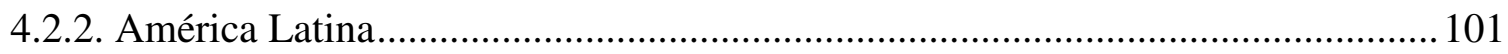

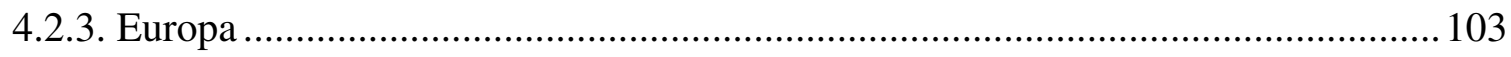

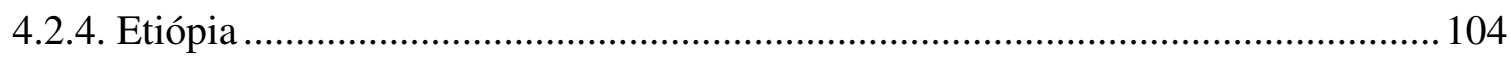

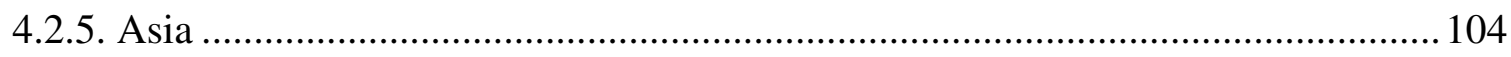

5. O RECALL E O SISTEMA JURÍDICO BRASILEIRO ............................................... 106

5.1. A revogação do mandato político no direito brasileiro ................................................. 106

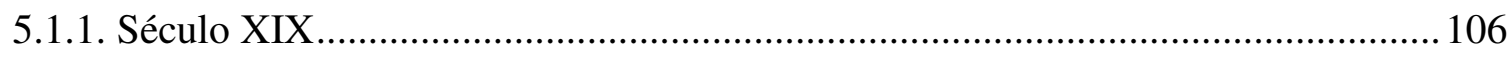

5.1.2. A revogação de mandato e a Constituição Federal .................................................. 107

5.1.2.1. O voto destituinte............................................................................... 107

5.1.2.2. A proposta de Emenda Constitucional $n^{\circ} 0073 / 2005$.............................. 108

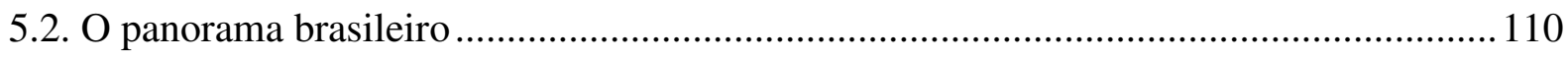

5.2.1. A representação política no Brasil ........................................................................ 111

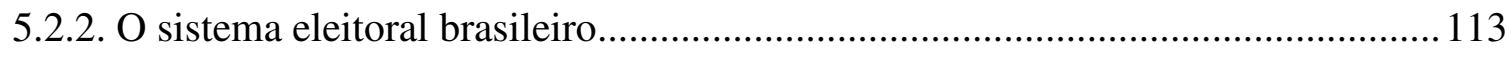

5.2.2.1. O desenvolvimento do sistema eleitoral brasileiro................................. 113

5.2.2.2. As eleições realizadas em distritos no Brasil........................................... 116

5.2.2.3. O projeto de lei $\mathrm{n}^{\circ} 1306 / 05$ de autoria do ex-deputado Franco

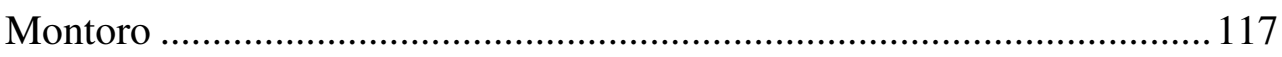

5.2.3. O mandato partidário. As decisões do Supremo Tribunal Federal e do Tribunal Superior Eleitoral sobre a titularidade do mandato político ................... 118

5.2.4. Autoridades que podem ser submetidas ao recall ................................................. 120

5.3. A questão da viabilidade do recall no direito brasileiro ............................................. 123

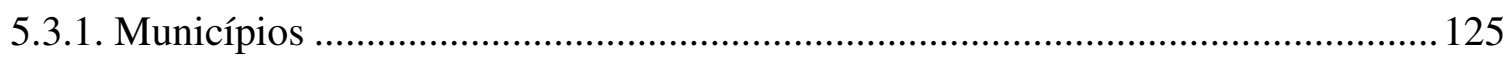

5.3.1.1. O desenvolvimento do Município no Estado brasileiro ........................... 125

5.3.1.2. O Município dentro da estrutura federativa........................................... 126

5.3.1.3. O recall no contexto do governo municipal .......................................... 128

5.3.2. O recall nos Estados-membros e em nível nacional .......................................... 131

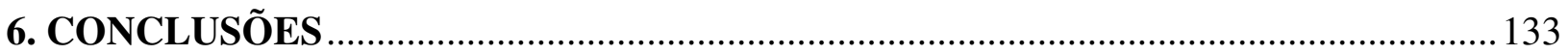

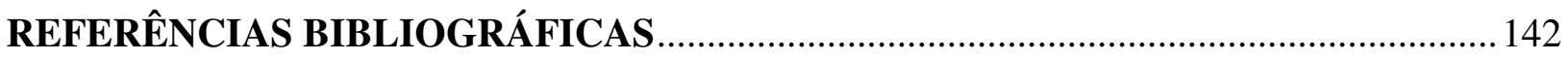




\section{INTRODUÇÃO}

A Constituição de 1988 significou um grande avanço em termos de democracia. O seu primeiro artigo inserido no Título I, que trata dos princípios fundamentais da República Federativa do Brasil, dispõe que o Estado brasileiro é democrático e de direito, e possui como fundamentos a soberania, a cidadania, a dignidade da pessoa humana, os valores sociais do trabalho e da livre iniciativa e o pluralismo político. Tal dispositivo trouxe também um novo elemento que é a conjugação de dois tipos de democracia: a representativa e a semidireta.

Embora seja cláusula essencial do sistema jurídico nacional, fundamento principal do Estado brasileiro, ponto de partida do direito positivo e valor principal a ser observado pelas autoridades públicas, há muito ainda a ser trilhado para se alcançar um Estado democrático satisfatório.

Após vinte anos da promulgação da Constituição, a democracia representativa tem apresentado falhas, principalmente no que diz respeito à representação dos eleitores e controle dos representantes. Os candidatos a deputado (estadual ou federal) durante a campanha eleitoral buscam votos em diferentes regiões. Quando eleitos, eles não representam ninguém, não possuem vínculo com os seus eleitores. O vínculo, hoje, no País, não é com as bases e sim com os meios, pois os nossos Tribunais decidiram que o mandato é de propriedade dos partidos políticos.

Por outro lado, os principais mecanismos de democracia semidireta previstos no art. 14 da Constituição não têm funcionado. E isso se deve a uma série de motivos, inclusive porque nos últimos vinte anos as questões relacionadas à estabilização econômica estiveram acima dos outros interesses nacionais. Certamente houve falta de empenho por parte dos políticos e, de certa forma, a sociedade não voltou seus interesses para as questões relacionadas à cidadania e à participação política, uma vez que grande parte da população esteve e ainda está concentrada no dia a dia da sobrevivência e do "ganha-pão". A iniciativa popular praticamente não produziu resultados. O plebiscito e o referendo dependem de iniciativa das casas legislativas, ou seja, são os representantes que decidem sobre a realização desses mecanismos de participação popular e não o povo. A legislação que foi editada no ano de 1998, pelo Congresso Nacional, para regular o art. 14 da 
Constituição Federal, não estimulou a utilização desses institutos de democracia semidireta.

Diante desse panorama, dentre as duas formas de exercício da soberania popular, verifica-se que o fenômeno da representação tornou-se mais importante do que a participação popular. Sendo essa, então, a forma preponderante pela qual tem se manifestado a soberania popular no país, a solução para se atingir uma democracia mais satisfatória, portanto, é o aperfeiçoamento da democracia representativa.

Nesse contexto, o recall, que será objeto de aprofundado estudo nesta tese, surge como elemento diferente, não como corretivo da democracia indireta, mas como elemento aperfeiçoador, como forma de controle do poder político e de aproximação entre representantes e representados.

O recall é um mecanismo existente nos Estados Unidos, no qual o eleitorado confirma ou revoga o mandato de uma autoridade pública ou revoga uma decisão judicial. Ao redor desse instituto circundam questões constitucionais que são extremamente relevantes para sua compreensão. Assim, a representação política, o sistema eleitoral, a responsabilidade dos representantes e a própria história são elementos essenciais para a compreensão do instituto do recall, razão pela qual, será inafastável, nesta tese, a abordagem desses temas.

Embora tenhamos que enfrentar diversas questões ao longo do caminho, o foco deste estudo será o recall norte-americano e sua aplicação nos Estados Unidos, bem como a aplicação no direito estrangeiro de institutos que a ele se assemelham e as possibilidades, dificuldades e benefícios relativos à adoção desse mecanismo no sistema jurídico brasileiro. Trata-se de uma proposta, de uma contribuição para o aperfeiçoamento da democracia no nosso país, que leva em consideração a essência e as características desse instituto. 


\section{A REPRESENTAÇÃo POLÍTICA}

\subsection{Definição}

Como averbado preliminarmente, constitui objeto deste estudo o recall norteamericano, os institutos a ele similares e as condições para sua aplicação no sistema jurídico brasileiro. O fio condutor desta tese é a revogação do mandato político dos representantes por decisão dos eleitores, mediante procedimento específico. A revogação das ordens judiciais mediante decisão popular também será objeto de análise, porém, com menor profundidade.

Tratando-se o recall de revogação de mandato de representante, é inevitável, procedermos a uma análise acerca do fenômeno representação política. Assim, inicialmente, faz-se necessária uma abordagem acerca de sua definição.

Definir a representação política e determinar sua essência não é tarefa fácil. Trata-se de um dos temas mais controvertidos do Direito Público que há tempos desperta discussões na doutrina, envolvendo não só Direito como também outras ciências. E assim ocorre porque a representação política ora envolve conceitos de Direito Privado ${ }^{1}$, ora de Direito Público, sem contar outras facetas que o assunto aflora quando é visto sob o ângulo do fato social ou mesmo pelo aspecto filosófico.

Há autores que procuraram definir a representação política.

Pinto Ferreira, por exemplo, vê a representação como "a situação políticojurídica na qual determinados indivíduos ou grupos sociais exercem as funções estatais em nome do povo". 2

Segundo Meirelles Teixeira, "um regime se diz representativo quando os governantes ou parte deles, exercem sua competência não em virtude de um direito próprio, mas em razão de sua qualidade de representantes, geralmente obtida mediante eleição e apenas por um certo prazo". Para ele, "a essência da representação consiste na

\footnotetext{
${ }^{1}$ Envolve conceitos de Direito Privado porque ainda hoje se discute a volta do mandato imperativo e a questão do vínculo entre representante e representado.

${ }^{2}$ FERREIRA, Luiz Pinto. Princípios gerais do direito constitucional moderno. 4. ed. São Paulo: Saraiva, 1962. p. 174.
} 
distinção entre o titular do poder político (povo), e os seus representantes, que desse poder têm apenas o exercício, geralmente durante certo tempo, apenas". 3

Por seu turno, Marcello Caetano afirma que representação política é “o princípio jurídico em virtude do qual um ou alguns indivíduos exercem o poder político ou participam no seu exercício em lugar e em nome dos titulares do referido poder e de modo que os actos dos representantes sejam considerados provenientes da autoridade dos representados". 4

Para Carl Friedrich, representação é "o processo através do qual a influência que todos os cidadãos, ou parte deles, detém sobre a ação governamental, se exerce, com sua expressa aprovação e em seu nome, por um reduzido número de pessoas (dentre o grupo) com a obrigatoriedade de respeito à vontade dos representados". 5

José Joaquim Gomes Canotilho anota que, representação política, “sob o ponto de vista organizatório-funcional, traduz-se num esquema de selecção fundamentalmente ancorado na eleição dos governantes através do qual: (1) se institui o exercício do poder político; (2) se institui o controlo exercido pelos representados". 6

Karl Loewenstein ${ }^{7}$ destaca que "La naturaleza jurídica de La representación es que los representantes - cualquiera que sea La manera de su investidura - reciben por adelantado el encargo y la autorización de actuar conjuntamente em nombre de sus representados, y de ligarles por sus decisiones coletivas".

Para Giovanni Sartori, a representação política não pode ser resolvida exclusivamente pelo jurista, porque se trata de tema complexo:

o que torna extremamente complicado o problema da representação política é não poder o assunto ser resolvido em nenhum destes setores de estudo. $\mathrm{O}$ homem dos fatos, o das idéias, e o jurista, enquanto permaneçam tais, isto é, exclusivamente no âmbito de suas respectivas especializações, iniciam uma exposição, a qual, porém, não conseguem terminar nem concluir. Ou melhor, cada qual procura, a seu modo, concluí-la: mas é fácil perceber que essas conclusões incluem sempre

${ }^{3}$ TEIXEIRA, J. H. Meirelles. Curso de direito constitucional. Texto revisto e atualizado por Maria Garcia. Rio de Janeiro: Forense, 1991. p. 487.

${ }^{4}$ CAETANO, Marcello. Manual de ciência política e direito constitucional. 6. ed. rev. e ampl. por Miguel Galvão Teles. Coimbra: Almedina, 1996. t. 1, p. 186.

${ }^{5}$ FRIEDRICH, Carl. Gobierno Constitucional y democracia, Madrid: Editorial Gráficas Espejo, 1976. p. 29 apud CAGGIANO, Monica Herman Salem. Sistemas eleitorais x representação política. 1987. Tese (Doutorado) - Faculdade de Direito, Universidade de São Paulo, São Paulo, 1987. p. 18.

${ }^{6}$ CANOTILHO, José Joaquim Gomes. Direito constitucional e teoria da Constituição. 4. ed. Coimbra: Almedina, 2000. p. 531.

${ }^{7}$ LOEWENSTEIN, Karl. Teoria de la constitución. Traducción y estúdio sobre la obra por Alfredo Gallego Anabitare. Barcelona: Ediciones Ariel, 1965. p. 57-58. 
implicitamente, e também subreptìciamente, algum elemento estranho, assimilado e absorvido de disciplinas correlatas. O jurista puro que queira chegar a uma conclusão, deverá ponderar elementos que, a rigor, são "extra jurídicos"; por sua vez, o cientista político que quiser limitar-se a ser mero registrador de fatos, deverá apelar para a "teoria" da política.

A verdade é que a representação política cobre todo o percurso que vai da política ao direito, e vice-versa. Nenhuma outra matéria, talvez, esteja tão sugestivamente ligada a estas duas séries de conceitos. As instituições representativas são ao mesmo tempo o anel de união e de desunião entre a posição do governar e do ser governado, entre o fazer leis e o ser subordinado a elas; e os mecanismos representativos são o trâmite de procedimentos por meio dos quais poder-se-ia dizer - um soberano se torna súdito novamente, e o súdito volta a ser novamente soberano. ${ }^{8}$

Há tempos o Direito procura estabelecer a essência da representação política buscando elementos para explicá-la.

Miguel Reale afirma que, depois de Kelsen e Hauriou, houve um esvaziamento do conceito jurídico de representação, que foi ocupado por teorias sociológicas. ${ }^{9}$

Depreende-se, portanto, que a representação política, hoje, não pode ser definida apenas do ponto de vista jurídico. Uma abordagem exclusivamente formal não é suficiente para explicar o fenômeno. ${ }^{10}$

Conquanto existam dificuldades na definição de representação política, é certo que determinados aspectos jurídicos são relevantes para sua compreensão. Assim, representar alguém significa dizer que atividades são realizadas por um representante em benefício de um representado. Em segundo lugar, é perceptível que existem dois polos de uma relação, de um lado o representante e, de outro, o representado. Resta saber se há ou não um vínculo entre esses dois polos. Se houver um vínculo, pode-se dizer que o caráter jurídico passa a ter maior importância no fenômeno. Ademais, a representação política necessariamente envolve um processo jurídico de escolha (eleição) baseado em regras, que se traduzem em normas jurídicas de estrutura e de comportamento, inclusive com aplicações de sanções. Envolve também um termo, um prazo, no qual a representação

${ }^{8}$ SARTORI, Giovanni. A teoria da representação no Estado representativo moderno. Traduzido por Ernesta Gaetani e Rosa Gaetani. Revista Brasileira de Estudos Políticos, Belo Horizonte, p. 15-16, 1962.

${ }^{9}$ REALE, Miguel. A teoria jurídica da representação política. In: SEMINÁRIO SOBRE MODELOS ALTERNATIVOS DE REPRESENTAÇÃO POLÍTICA NO BRASIL, Painel II, Brasília: Ed. da UnB, 1981, p. 45-46.

${ }^{10}$ Celso Fernandes Campilongo observa que a representação política possui uma dimensão formal e outra substantiva, havendo, portanto, duas formas de abordagem do fenômeno. A primeira, pelo aspecto estrutural, baseada no prisma normativo e a segunda, pelo aspecto funcional, que não pretende complementar a primeira, mas identificar as funções da representação. (CAMPILONGO, Celso Fernandes. Representação política. São Paulo: Ática, 1988. p. 7-11). 
política é exercida; implica também mandato, exercício de função pública do Estado (executiva, legislativa ou judiciária) e responsabilidade política. Portanto, não faltam elementos jurídicos na representação política.

A seguir, por meio de uma abordagem histórica, examinaremos a representação política e suas teorias. Ao longo desta análise, será possível verificar que as justificativas sobre a representação basearam-se em métodos distintos (jurídicos, sociológicos, ou até mesmo filosóficos).

\subsection{A Evolução Histórica da Representação Política}

\subsubsection{Formas de representação na Antiguidade}

Nas sociedades antigas não existia a representação política como instituto. Existiam apenas alguns traços de representação, pois a maioria das decisões políticas era tomada mediante participação direta da população, sem intermediários.

No Estado Grego a classe política era constituída por uma elite, que participava ativamente das decisões de caráter coletivo. Os indivíduos que compunham essa classe eram considerados cidadãos e participavam do funcionamento das Cidades-Estado e constituíam uma faixa restrita da população. ${ }^{11}$ A participação política realizava-se, geralmente, por meio de assembleias, que consistiam em votação de leis e decisões sobre o exercício de funções públicas.

No início da sociedade romana, apenas os patrícios participavam das decisões políticas. Com a expansão do Estado Romano, os plebeus passaram a adquirir direitos de participação política. No início do século V a.C. a plebe conquista o direito de formar sua própria assembleia e em 287 a.C. surge a Lex Hortensia instituindo o plebiscito. ${ }^{12}$ Durante a República havia o instituto da provocatio ad populum, que permitia ao condenado a penas graves recorrer ao julgamento do povo. ${ }^{13}$

Esses exemplos históricos acerca das origens da participação política constituem o que a doutrina denomina de "democracia direta dos antigos", ou seja, formas

\footnotetext{
${ }^{11}$ DALLARI, Dalmo de Abreu. Elementos de teoria geral do Estado. São Paulo: Saraiva, 2005. p. 64.

${ }^{12}$ PERRY, Marvin. Civilização ocidental: uma história concisa. Tradução de Waltensir Dutra e Silvana Vieira. 2. ed. São Paulo: Martins Fontes, 1999. p. 90.

${ }^{13}$ COMPARATO, Fábio Konder. A nova cidadania. Lua Nova: revista de cultura e política São Paulo, n. 289, p. 86, 1993.
} 
de participação nas quais ocorriam manifestações constantes e diretas dos indivíduos, com o conhecimento imediato da vontade popular.

A participação direta só foi possível nessas sociedades em razão do pequeno número de pessoas envolvidas no processo de decisão, bem como em razão do limitado espaço geográfico onde eram realizadas tais atividades políticas.

Nas sociedades antigas, embora houvesse prevalência de participação direta, já existiam formas primitivas de representação dos grupos sociais, principalmente na Grécia e em Roma.

Segundo Fustel de Coulanges ${ }^{14}$, na Grécia Antiga havia os magistrados que exerciam funções anuais. Os magistrados-sacerdotes eram escolhidos por sorteio e os magistrados que exerciam funções de ordem pública eram eleitos diretamente pelo povo. Para esses últimos, havia uma espécie de investigação prévia feita sobre a probidade do candidato e de sua família (realizada pelos próprios magistrados ou pelo senado), não sendo exigida nenhuma comprovação prévia de talento ou capacidade. Tais magistrados que exerciam funções públicas não-sacerdotais eram respeitados pela comunidade, pois o sufrágio consistia em uma das fontes sagradas de autoridade. Além disso, eram responsáveis pelos seus atos, deviam prestar contas de sua atuação e podiam ser destituídos do cargo pelo voto popular.

James Madison ${ }^{15}$, em Os Artigos Federalistas, também registrou que a representação não era desconhecida dos povos antigos:

Nas mais puras democracias da Grécia muitas funções executivas eram desempenhadas não pelo próprio povo, mas por funcionários eleitos pelo povo, que o representavam em seu poder executivo.

Antes da reforma de Sólon, Atenas foi governada por nove arcontes, eleitos anualmente pelo povo em geral. $\mathrm{O}$ grau de poder a eles delegado parece ter ficado muito obscuro. Em período posterior, encontramos uma assembléia, primeiro com quatrocentos membros e mais tarde com seiscentos, anualmente eleita pelo povo e representando-o parcialmente em seu poder legislativo, pois seus membros não só se associavam ao povo na função de fazer leis como tinham o direito exclusivo de apresentar propostas legislativas ao povo. Verifica-se que também o senado de Cartago, fosse qual fosse seu poder ou a duração do mandato dos seus membros, era eleito pelo sufrágio do povo. Casos similares podem ser encontrados na maioria dos governos populares da Antiguidade, se não em todos.

\footnotetext{
${ }^{14}$ COULANGE, Fustel de. A cidade antiga: estudos sobre o culto, o direito; as instituições da Grécia e Roma. Tradução de Jonas Camargo Leite e Eduardo Fonseca. São Paulo: Hemus, 1975. p. 263.

${ }^{15}$ OS ARTIGOS federalistas (1787/1788): James Madison, Alexander Hamilton, John Jay. Ed. integral. Tradução: Maria Luiza X. de A. Borges. Rio de Janeiro: Nova Fronteira, 1993. p. 408.
} 
Em Esparta encontramos os éforos, e em Roma os tribunos. Compunham dois corpos, mas eram anualmente eleitos pelo povo e considerados como seus representantes em caráter quase plenipotenciário. Os cosmos do Creta eram também anualmente eleitos pelo povo e foram considerados por alguns autores uma instituição análoga às de Esparta e de Roma, com a única diferença de que na eleição desse corpo representativo o direito de sufrágio era conferido apenas a uma parte do povo.

Estes fatos, a que muitos outros poderiam ser acrescentados, deixam claro que o princípio da representação não era desconhecido pelos antigos, nem inteiramente desprezado em seus modos de organização política.

Menos entusiasmados, Duguit e Jellinek afirmaram que na Roma Antiga já existiam traços da representação política ${ }^{16}$. Esse último autor afirma que, em princípio, a representação era estranha aos Estados Antigos. Não havia necessidade de representação nas assembleias e nos conselhos populares. No entanto, para Jellinek, as ações dos magistrados, realizadas nos limites de suas competências, eram consideradas ações do próprio povo e, na época do Principado, já desaparecida a ideia da responsabilidade das altas magistraturas, surge a convicção, expressada por Ulpiano, de que o príncipe havia reivindicado para si todo o direito do povo, sendo o único representante deste. Além disso, com o fim dos comícios, o Senado passou a adquirir para os romanos um valor representativo. $^{17}$

Traços de representação existiram também em outros povos no passado, fora do Continente Europeu, a exemplo dos aborígenes australianos ${ }^{18}$ e dos indígenas brasileiros $^{19}$. No entanto, as experiências da Grécia e Roma antigas possuem um significado maior, pela influência natural desses dois sistemas sobre os sistemas ocidentais.

\footnotetext{
${ }^{16}$ DUGUIT, León. Traité de Droit Constitutionnel; JELLINEK, Georg, Allgemeine Staatslebre Apud SOUZA, José Pedro Galvão de. Da representação política. Tese (Livre Docência de Teoria Geral do Estado) - Faculdade de Direito, Universidade de São Paulo, São Paulo, 1971. p. 12.

${ }^{17}$ JELLINEK, G. Teoria general del Estado. Tradución y prólogo de la 2. ed. alemana por Fernando de los Rios Urruti. Granada: Editorial Comares, 2000. p. 561-562. Nesse sentido, cf. tb. DUGUIT, León apud TEIXEIRA, J. H. Meirelles. op. cit., p. 487.

${ }^{18}$ Entre os aborígenes da Austrália, os ministros de culto chamados "alantujas" convocavam membros do clã totêmico para ritos habituais. Nessas reuniões, segundo Moret e Davy, verifica-se um esboço de um governo representativo (e até federativo) exercido pelas assembleias dos chefes locais, com deliberações que excediam os limites do clã e que se estendiam por toda a tribo (MORET. A; DAVY G. Des clans aux empires, La renaissance di livre, Paris, 1923 apud SOUZA, José Pedro Galvão de. op. cit., p. 10).

${ }^{19}$ Afonso Arinos de Melo Franco registra que "entre as tribos indígenas do Brasil, ao tempo do descobrimento, os cronistas e viajantes do primeiro século (que são os nossos primeiros observadores sociais) deixam ver, nas suas narrativas, que o conjunto das tribos era sempre representado por chefes escolhidos de forma diversa, cercado ou não de conselheiros, mas que representavam, incontestavelmente, a maioria ou a totalidade dos componentes da nação indígena em causa" (FRANCO, Afonso Arinos de Melo. Representação popular. In: SEMINÁRIO SOBRE MODELOS ALTERNATIVOS DE REPRESENTAÇÃO POLÍTICA NO BRASIL. Brasília: Ed. da UnB, 1981. p. 7).
} 
Há autores, no entanto, que entendem de forma contrária, a exemplo de Karl Loewenstein $^{20}$ que vê a representação política como um fato desconhecido tanto na Antiguidade como na Idade Média.

Para Norberto Bobbio, a democracia dos antigos era realizada pela via direta, às vezes corrigida pela eleição de algumas magistraturas. A regra era a participação direta e a eleição, a exceção, diferentemente do que ocorre nos dia de hoje. ${ }^{21}$

De fato, existiram formas primitivas de representação no passado remoto. No entanto, embora os autores divirjam sobre a intensidade dessas formas de representação nas sociedades antigas, as primeiras instituições representativas, que podem ser consideradas o embrião do sistema hoje existente, encontram-se no período medieval.

\subsubsection{A Representação Política na Idade Média}

\subsubsection{As raízes da representação política}

A Idade Média caracterizou-se por instabilidades sociais, econômicas e políticas.

Nesse período da história da humanidade, havia grande desagregação política. A forte presença do Cristianismo afirmava a unidade da igreja com base na igualdade e fraternidade entre cristãos. Por outro lado, havia as invasões dos povos bárbaros e o sistema feudal que valorizava enormemente a posse de terra. ${ }^{22}$

A Idade Média foi também marcada por guerras privadas entre os senhores feudais, com frequentes pilhagens, matanças e incêndios criminosos. Em razão dessas guerras e invasões, o sistema feudal priorizou as relações internas dos feudos.

Foi no período medieval, caracterizado por esses fatos, que surgiram as raízes do modelo representativo, na sua forma embrionária.

No século XIII, como assinalou José Pedro Galvão de Souza ${ }^{23}$, havia os registros históricos das assembleias representativas de várias categorias sociais existentes

\footnotetext{
${ }^{20}$ LOEWENSTEIN, Karl. op. cit., p. 58.

${ }^{21}$ BOBBIO, Norberto. Teoria geral da política: a filosofia política e a lição dos clássicos. Organizado por Michelangelo Bovero. Tradução de Daniela Beccaria Versiani. Rio de Janeiro: Campus, 2000. p. 374.

${ }^{22}$ DALLARI, Dalmo de Abreu. op. cit., p. 66 e 69.

${ }^{23}$ SOUZA, José Pedro Galvão de. op. cit., p. 123-133.
} 
na Inglaterra, Espanha e em outros países europeus. Nessa época, as Cortes dos monarcas funcionavam precariamente como conselhos. Os representantes da nobreza e do clero reuniam-se para a realização de conselhos consultivos para tratar de assuntos de natureza política e deliberação sobre leis e impostos. Na Espanha, o sistema representativo se esboçou antes da Inglaterra, com a participação do elemento popular nas assembleias legislativas. Nos concílios de Toledo, quando as assembleias já não eram mais apenas eclesiásticas, a capacidade legislativa pertencia ao rei e desta autoridade surgiam as leis, após consulta dos elementos representativos das comunidades. Outro aspecto relacionado à origem do modelo representativo pode ser encontrado nas organizações corporativas das pequenas indústrias e do comércio dos feudos, assim como, também, no fato de que as ordens religiosas se utilizavam de modelos representativos para realizar eleições para o estabelecimento do poder clérigo.

Biscaretti Di Ruffia ${ }^{24}$ delineia com precisão o modus operandi do sistema representativo medieval:

os Parlamentos medievais - constituídos, diretamente ou por representação, pelos três estados da nobreza feudal, dos altos dignatários eclesiásticos e da classe burguesa - se contrapunham às pretensões de dominação do soberano, apoiando-se nos deveres e direitos recíprocos que dimanam do contrato feudal. Com efeito, toda vez que se saísse da normal contribuição das prestações recíprocas, era mister convocar os três estados a fim de que concedessem ao Monarca a percepção de novos impostos, até então não contemplados nos pactos de vassalagem, ou para que amparassem sua decisão de iniciar uma guerra ou de concluir a paz. Ao mesmo tempo, os Parlamentos manifestam ao Rei as necessidades do País (sobre as condições locais da agricultura, da indústria, da viabilidade da ordem pública, etc) e expunham as queixas dos súditos quanto aos abusos realizados no exercício dos vários serviços públicos.

Adotavam nomes diversos nos diferentes países (Estados Gerais, na França e no Piemonte; Estamentos, na Sardenha; Parlamentos, em Nápoles e na Sicília; Cortes, na Espanha) e enquanto que, num primeiro tempo, eram formados apenas pelos dois estados da nobreza e do alto clero, num segundo tempo, e especialmente para contrabalançar o domínio das duas ordens, os Príncipes fizeram intervir também um terceiro estado, mas apenas por meio de representantes, dado o número muito maior de seus componentes. As várias comunidades chamadas para que enviassem delegados (meliores terrae), costumavam dar aos próprios eleitos o mandato para pronunciar-se de um modo determinado sobre aqueles problemas para cuja solução se convocava o Parlamento; e os delegados comprometiam os grupos representados apenas dentro dos limites do mandato recebido (os chamados cahiers dos Estados Gerais franceses, que originavam uma autêntica representação jurídica de vontade, baseada num mandato imperativo).

\footnotetext{
${ }^{24}$ DI RUFFIA, Paolo Biscaretti. Direito constitucional (instituições de direito público). Tradução de Maria
} Helena Diniz. Revisão de Ricaro Olivo. São Paulo: Ed. Revista dos Tribunais, 1984. p. 239. 
O sistema representativo medieval caracterizou-se, portanto, pelas funções predominantemente consultivas das assembleias e pela representação restrita a determinadas categorias sociais, que outorgavam mandatos a representantes que se obrigavam a obedecer à risca as ordens dos representados.

A representação possuía, portanto, um caráter estritamente vinculado. O mandato era de natureza civilista e se revestia, de um lado, pela transferência de poderes e, de outro, pela reserva de poderes que permitia ao mandante revogá-lo.

\subsubsection{A teoria do mandato imperativo}

A primeira teoria sobre a representação política, de cunho jurídico, foi a teoria do mandato imperativo.

León Duguit, ao tratar do tema, explica que os cidadãos, na qualidade de titulares individuais de uma parcela da soberania, participavam da eleição e escolhiam um representante que só poderia retirar seu poder daqueles que o designaram, sendo apenas um mandatário dos eleitores, permanecendo a soberania com esses últimos. O representante ou deputado, segundo essa teoria, é o mandatário da circunscrição, ou seja, do grupo de eleitores que o nomearam. Por esse motivo, o representante submetia-se a todas as obrigações que cabiam ao mandatário, e os eleitores, como mandantes, podiam limitar o mandato outorgado, traçando previamente a conduta que deveria ser seguida pelo representante, que deveria se submeter a instruções, votando em conformidade absoluta com estas. Caso o mandatário extrapolasse os poderes que lhe foram conferidos, os mandantes poderiam revogar o mandato outorgado. ${ }^{25}$

De acordo com as observações de Barthelemy e Duez ${ }^{26}$, na Antiga França, toda a teoria relacionada aos estados-gerais baseava-se na ideia de mandato imperativo até as suas últimas consequências. O deputado nos estados-gerais era o autêntico mandatário daqueles que o haviam eleito. Este deveria comparecer munido do título escrito que demonstrava a sua situação de mandatário e o primeiro ato dos estados gerais, assim que estivessem reunidos, consistia em verificar se todos os deputados possuíam poderes constituídos regularmente. O rei convocava os estados-gerais e formulava questões aos

\footnotetext{
${ }^{25}$ DUGUIT, León. Traité de droit constitutionnel, Ancienne Librairie Fontemoing \& Cie, Éditeurs, E. de Boccard, Successeur, 1924., p. 509 apud FERREIRA, Luiz Pinto. op. cit., p. 176.

${ }^{26}$ BARTHÉLEMY, Joseph; DUEZ, Paul. Traité elémentaire de droit constitutionnel. Paris: Dalloz, 1926. p. 92-93.
} 
mandatários. Prevenidos, os eleitores indicavam aos seus deputados como eles deveriam responder às formulações do rei. Durante a sessão, se o rei formulasse uma questão distinta daquelas que constavam do ato de convocação, os deputados respondiam que eles haviam sido enviados aos estados-gerais para ouvir e opinar, e que a questão não poderia ser respondida naquele instante porque, sobre o tema, não haviam recebido instruções dos eleitores, solicitando, assim, o adiamento da sessão para permitir-lhes ouvir seus eleitores e receberem novas instruções.

Monica Herman Salem Caggiano observa que "a moldagem medieval da representação resultava de uma clara transposição do mandato do direito civil para a esfera do direito público, implicando uma estreita vinculação entre o representante e a comunidade que o elegera". ${ }^{27}$

De fato, a teoria do mandato imperativo foi construída com base no direito privado, especialmente no instituto do mandato, figura do direito romano e civil, que envolvia uma nítida relação de confiança. O mandato imperativo implicava uma absoluta vinculação e relação de dependência à vontade do representado.

As razões que justificaram tal figura foram bem expostas por Pinto Ferreira:

As causas sociais e políticas motivadoras do mandato imperativo devemse de início à falta de unidade nacional dos países europeus, apenas saídos do feudalismo, com a sua situação de esfacelamento do poder estatal, na justaposição mal alinhavada dos interêsses locais e regionais, bem como das lutas ou conflitos das diversas ordens sociais, Localismo esse que impedia a visão de diretrizes políticas nacionais. Sôbre isso, convém salientar que a Europa dava os primeiros passos no caminho do regime representativo, razão pela qual não existiam assembléias legislativas permanentes, mas sòmente estados gerais convocados excepcionalmente, aos quais o monarca formulava poucas perguntas, com respostas de antemão previstas pelos eleitores. E afinal os referidos "estados gerais" tinham uma função puramente consultiva e não obrigatória, pela qual era possível à coroa o conhecimento da opinião geral das classes dominantes. ${ }^{28}$

Embora existissem sistemas de representação semelhantes nos reinos medievais, a longa história da criação do parlamento inglês é considerada referência para compreensão do governo representativo.

\footnotetext{
${ }^{27}$ CAGGIANO, Monica Herman Salem. op. cit., p. 16.

${ }^{28}$ FERREIRA, Luiz Pinto. op. cit., p. 177.
} 


\subsubsection{A formação do governo representativo na Inglaterra e as noções sobre representação dos pensadores ingleses}

\subsubsection{O contexto histórico e social da formação do governo representativo}

O processo histórico do governo representativo, na Inglaterra, teve início na Baixa Idade Média.

Quando Guilherme, Duque da Normandia, invadiu a Inglaterra (1066-1087) e, após tornar-se rei, promoveu a expropriação das terras dos vencidos, distribuindo-as em pequenos e esparsos feudos, consagrou-se, assim, como grande senhor feudal, apesar da resistência da nobreza anglo-saxônica. ${ }^{29}$

No século seguinte, sobe ao trono a dinastia dos Plantageneta, também de origem normanda e grande possuidora de feudos na França. Esse fato criou para essa dinastia uma situação contraditória, pois na Inglaterra eram monarcas que se empenhavam em exercer a autoridade real e, na França, como senhores feudais, empenhavam-se em combater a monarquia francesa, dando prioridade a essa última situação. A consequência desse comportamento foi o inevitável desgaste do poder real perante os nobres, clero e burgueses ingleses, o que obrigou o rei a reduzir seus poderes políticos. Assim, em 1215, foi imposta ao Rei João sem Terra a Magna Carta, na qual foram fixados os deveres e direitos do rei e dos vassalos. Dentre outros assuntos, a Magna Carta estabeleceu que o rei não poderia exigir impostos sem o prévio consentimento dos súditos. Foram instituídas também as bases do habeas corpus, criou-se o direito de insurreição caso o rei desrespeitasse os direitos dos vassalos ou os seus próprios deveres, bem como os fundamentos do governo representativo, dentre outros direitos e deveres. ${ }^{30}$ Posteriormente, no reinado de Henrique III (1227-1272) surge o Parlamento, composto pelos representantes do clero, da nobreza, da burguesia e da pequena nobreza. ${ }^{31}$

Os ingleses consideram como precedente decisivo do governo representativo o Parlamento convocado em 1295 por Eduardo I, quando, pela primeira vez, a nação inteira

\footnotetext{
${ }^{29}$ AQUINO, Rubim Santos Leão et al. História das sociedades modernas às sociedades atuais. Rio de Janeiro: Record, 2001. p. 68-71.

${ }^{30}$ MAGNA Carta is one of the most celebrated documents in history. Examine the British Library's copy close-up, translate it into English, hear what our curator says about it, and explore a timeline. Disponível em: <http://www.bl.uk/treasures/magnacarta/index.html\#>. Acesso em: 05 jan. 2009.

${ }^{31}$ AQUINO, Rubim Santos Leão et al. op. cit., p. 68-71.
} 
encontrava-se representada. A importância dos comuns, a partir daí, cresce rapidamente e o consentimento dessa classe passa a ser necessário para a elaboração das leis. ${ }^{32}$

Foi no século XIV que o Parlamento Inglês se dividiu em duas câmaras distintas: de um lado, a Câmara dos Lordes, constituída pelos grandes senhores feudais e eclesiásticos, e de outro, a Câmara dos Comuns, constituída pela pequena nobreza e pela burguesia.

O parlamento, no sentido técnico da palavra, passou a ser considerado a reunião e o acordo final do rei, da Câmara dos Lordes e da Câmara dos Comuns. ${ }^{33}$

Com a Guerra dos Cem Anos o Parlamento passou a ter maior importância, ascendendo ao poder a dinastia de Lancaster (1399-1485). A derrota inglesa na Guerra dos Cem Anos ensejou a Guerra das Duas Rosas (1455-1485) entre as casas reais de York e de Lancaster, as quais buscavam compensações pela perda de feudos na França, saindo-se vitoriosa a casa real de Lancaster, liderada por Henrique VII, que promoveu a unidade da Inglaterra. Arruinada, a nobreza feudal se desintegrou e, consequentemente, o Parlamento inglês se enfraqueceu. A consequência disso foi o fortalecimento do poder real e o surgimento de uma classe burguesa forte. Após a Guerra das Duas Rosas, Henrique VII sobe ao trono e surge a dinastia Tudor, que marcou o início do absolutismo inglês. Durante a dinastia Tudor o parlamento inglês continuou sendo convocado pelo monarca, mas tal ato não passou de demagogia do rei e de seus sucessores. A dinastia Tudor chega ao final com a morte da rainha Elisabete I, última representante dessa família que não deixou descendentes. Sobe então ao trono Jaime I (1603-1625), dando início à dinastia Stuart. ${ }^{34}$

Em 1640, a Inglaterra entra em uma sangrenta guerra civil, motivada pela rivalidade entre o Parlamento e o rei Carlos I. Em 1649 encerra-se a guerra civil, com a vitória dos defensores do parlamento. Após o final da guerra civil, surge o protetorado de Cromwell que, com apoio dos burgueses e do exército, levou a Inglaterra a se firmar como grande força comercial e naval. ${ }^{35}$

\footnotetext{
${ }^{32}$ ESMEIN apud TEIXEIRA, J. H. Meirelles. op. cit., p. 491.

${ }^{33}$ FERREIRA, Luiz Pinto. op. cit., p. 166.

${ }^{34}$ AQUINO, Rubim Santos Leão et al. op. cit., p. 68-71.

${ }^{35}$ Id. Ibid., p. 68-71. Cf. tb. MELLO, Leonel Itaussu Almeida. John Locke e o individualismo liberal. In: WEFFORT, Francisco C. (Org.). Os clássicos da política: Maquiavel, Hobbes, Locke, Montesquieu, Rousseau e "O Federalista”. 13. ed. São Paulo: Ática, 2001. p. 81-82.
} 


\subsubsection{Thomas Hobbes. A representação no sentido de autoridade}

Durante a dinastia dos Cromwell, em 1651, Thomas Hobbes publica sua célebre obra "O Leviatã" e nela é encontrada uma formulação pioneira sobre a representação política: ${ }^{36}$

Quanto às pessoas artificiais, em certos casos algumas de suas palavras e ações pertencem àqueles a quem representam. Nesses casos a pessoa é o autor, e aquele a quem pertencem suas palavras e ações é o autor, casos estes em que $o$ ator age por autoridade.

E mais à frente afirma:

De modo que a autoridade se entende sempre o direito de praticar qualquer ação, e feito por autoridade sempre feito por comissão ou licença daquele a quem pertence o direito.

Sobre a visão de representação em Hobbes, Maria D'alva Gil Kinzo assevera que esta "está intimamente ligada à idéia de autoridade; mais precisamente, é o próprio conceito de autoridade que faz possível pensar em representação". E logo a seguir acrescenta: "partindo da idéia de estado de natureza onde a luta permanente de uns contra os outros por desejos conflitantes impossibilitaria a convivência entre os homens, Hobbes deduz a necessidade de um pacto social a fim de criar uma união duradoura entre eles. É devido a essa necessidade que os homens criam um Estado, autorizando um entre eles a representá-los". 37

Para Olavo Brasil Lima Júnior ${ }^{38}$, a principal preocupação de Hobbes consistiu na justificação do absolutismo, oferecendo os fundamentos que legitimariam sua autoridade. Autorização e delegação de poder constituem-se em elementos essenciais que vinculam a pessoa ao poder, sendo essa a única solução para a sobrevivência em um mundo baseado na guerra de todos contra todos. Ainda, segundo o referido autor, a representação em Hobbes assume os seguintes traços distintivos: a) constitui governo

\footnotetext{
${ }^{36}$ HOBBES, Thomas. O Leviatã ou matéria: forma e poder de um Estado eclesiástico e civil. Tradução de João Paulo Monteiro e Maria Beatriz Nizza da Silva. São Paulo: Nova Cultural, 1999. p. 135-136. Hanna Pitkin afirma que o tema representação desempenha um papel central na obra de Hobbes, embora as análises clássicas não reconheçam esse aspecto no filósofo inglês. (PITKIN, Hannah Fenichel. El concepto de representacion. Tradução de Ricardo Montoro Romero. Madrid: Centro de Estudios Constitucionales, 1985. p. 15).

${ }^{37}$ KINZO, Maria D’alva Gil. Representação política e sistema eleitoral no Brasil. São Paulo: Edições Símbolo, 1980. p. 22.

${ }^{38}$ LIMA JÚNIOR, Olavo Brasil de. Instituições políticas democráticas: o segredo da legitimidade. Rio de Janeiro: Jorge Zahar, 1997. p. 37-39.
} 
legítimo que, por sua ação, a todos subjuga; b) o poder instituído é uno e indivisível, seja ele exercido por uma única pessoa ou por uma assembleia; c) a representação assume feição mecânica e d) não há responsabilidade por parte do representante, que é soberano e a sobrevivência é justificativa moral para a constituição da autoridade.

A noção de representação em Hobbes justifica o poder do soberano, com base na ideia de autoridade. Para os homens sobreviverem em um mundo caótico, no qual o estado de natureza é a regra, a razão humana leva à celebração de um contrato social para que um único indivíduo ou um grupo represente a todos, autorizando esse representante ou grupo de representantes a representá-los, sem responsabilidade por seus atos, que assume suas funções em prol da sobrevivência do corpo social.

Esta é, portanto, segundo autores renomados, a primeira noção de representação que surgiu no Estado moderno, no sentido de autoridade.

\subsubsection{A Revolução Gloriosa e o Poder Legislativo de John Locke}

Em 1669, com o fim do protetorado de Cromwell, para evitar uma crise política e uma nova guerra civil, sobe novamente ao trono a dinastia Stuart. O período compreendido entre 1660 até a Revolução Gloriosa de 1688 foi denominado pelos historiadores de Restauração ${ }^{39}$. O início desse período foi marcado por um novo acirramento de ânimos entre o Parlamento e a monarquia. ${ }^{40}$

Em 1680 o Parlamento divide-se em dois partidos: os Whigs, que defendiam a monarquia limitada pelo parlamento e os Tories, que defendiam os poderes do monarca. $\mathrm{O}$ período da Restauração entrou em crise profunda quando Jaime II, governando de forma despótica, tenta restabelecer o catolicismo contrariando frontalmente os interesses da maioria protestante. Em razão desse fato, Whigs e Tories se unem e juntamente com Guilherme de Orange, genro de Jaime II e príncipe da Holanda, organizam a Revolução de 1688 - a Revolução Gloriosa - depondo a dinastia Stuart e assegurando vários direitos aos burgueses protestantes ingleses por meio da aprovação do Bill of Rights em 1689, quando se consagrou definitivamente o sistema representativo na Inglaterra, com eleições livres

\footnotetext{
${ }^{39}$ Restauração da Dinastia Stuart.

${ }^{40}$ MELLO, Leonel Itaussu Almeida. op. cit., p. 81-82.
} 
para deputados e com a supremacia do Parlamento sobre o poder real, instituindo-se o regime monárquico limitado. $\mathrm{O}$ Parlamento se afirmou perante o rei. ${ }^{41}$

A Revolução Gloriosa, no entanto, não consagrou um sistema democrático amplo, mas sim um sistema aristocrático no qual seriam afirmados os direitos e valores fundamentais da nova classe social burguesa protestante.

Em 1690, pouco tempo depois da Revolução e após retornar da Holanda, John Locke publica o Segundo Tratado Sobre o Governo Civil.

Para Locke ${ }^{42}$, o maior objetivo dos homens, quando entram em sociedade, é desfrutar de sua propriedade de forma pacífica e sem riscos e a lei seria o instrumento garantidor desse objetivo. A primeira lei fundamental de todos os agrupamentos políticos seria o estabelecimento do Poder Legislativo, considerado o poder supremo da comunidade civil, exercido por uma pessoa ou grupo de pessoas, de forma permanente ou intermitente, limitado, no entanto, por quatro fatores: a) o Poder Legislativo deve governar por meio de leis estabelecidas e promulgadas, devendo abster-se de modificá-las em casos particulares; b) as leis devem ter por finalidade o bem comum; c) quando permanente ou quando houver eleições periódicas de representantes, o Poder Legislativo não deve fixar impostos sobre a propriedade do povo, sem que este expresse seu consentimento de forma individual ou por meio de representantes, e d) o Poder Legislativo não pode transferir para outros o poder de legislar, que lhe foi confiado pelo povo.

Locke afirma também que o Poder Legislativo, apesar de ser supremo, é um poder fiduciário limitado a fins determinados, permanecendo no povo um poder superior para destituir ou alterá-lo quando o ato legislativo promulgado por este poder for contrário à confiança nele depositada.

Há, em Locke, pois, uma noção de representação menos intensa e diferente da de Hobbes. Neste, como dito, o soberano recebe autorização e delegação de poder por parte dos súditos por meio de um contrato, para governar em nome destes, evitando a destruição da comunidade que vive em permanente conflito. A justificativa da representação em Hobbes é evitar a guerra de todos contra todos. O soberano representa os súditos que o colocaram em tal posição para protegê-los da natural situação de hostilidade

\footnotetext{
${ }^{41}$ MELLO, Leonel Itaussu Almeida. op. cit., p. 82.

${ }^{42}$ LOCKE, John. Segundo tratado sobre o governo civil e outros escritos: ensaio sobre a origem, os limites e os fins verdadeiros do governo civil. Tradução de Magda Lopes e Marina Lobo da Silva. Petrópolis, RJ: Vozes. 1999. p. 162-169 e p. 173.
} 
existente entre os homens. Por sua vez, em Locke, a representação não tem como justificativa a contenção do estado de conflito entre os homens, mas sim, quando presente o consentimento popular por meio de representantes, a proteção da propriedade dos representados, que não podem ter seus bens usurpados por meio de tributação nãoconsentida ou qualquer ato de autoridade não-consentido. Agindo o Parlamento de forma contrária ao que foi consentido, esse poder poderá ser destituído ou alterado. A destituição, no caso, não deve ser entendida como uma questão relacionada ao mandato, ao vínculo entre representante e representado, mas sim como uma questão relacionada ao sistema de governo, à quebra de confiança no parlamento. Não há em Locke uma preocupação centralizada na relação entre representante e representado. A preocupação do filósofo inglês não é a atuação dos agentes. O foco é o Parlamento como poder, que não está autorizado a agir de forma contrária às razões de sua instituição, que é garantir aos súditos, por meio de leis estabelecidas, o desfrute de suas propriedades de forma pacífica e sem riscos. O parlamento representa o povo para que os homens que integram esse povo possam gozar de suas vidas e propriedades livremente.

Embora não esteja clara, na obra de Locke, a forma em que ocorria a relação entre representante e representado, pode-se inferir que a preocupação principal do filósofo inglês não era com a relação individual e com o mandato. A preocupação central era com o parlamento em si, como instituição, que representava o povo inglês. O consentimento do parlamento equivale ao consentimento do próprio povo, como um todo. A representação, aqui, envolve duas coletividades: o parlamento e o povo.

\subsubsection{Edmund Burke e o mandato livre}

A preocupação com a questão da relação entre representantes e representados e a negativa do mandato imperativo só aparecem, de forma ostensiva, no século XVIII, principalmente com Edmund Burke, parlamentar de origem irlandesa, membro da Câmara dos Comuns e do partido Whig. ${ }^{43}$

\footnotetext{
${ }^{43}$ A negação do mandato imperativo, no entanto, não é uma idéia original de Burke, pois há registros de que, em 1701, essas concepções já apareciam nos escritos do filósofo John Toland e do deputado Humphrey Mackworth, ambos ingleses (ESMEIN, A. Eléments de Droit Constitutionnel apud SARTORI, Giovanni. op. cit., p. 25). O jurista inglês William Blackstone também tratou da questão do mandato livre: "A assembléia dos pares laicos e eclesiásticos, unida aos comuns, formam agora o regnum; e assim o membro particular do parlamento é uma parte da representação do império; sua vontade não é a vontade da coletividade que o elegeu, porém um elemento da vontade de todo o império" (BLACKSTONE, William. Commentaries on the laws of England. Dublin, 1773, Vol. I, p. 146 apud FERREIRA, Luiz Pinto. op. cit., p. 179).
} 
Burke, no seu famoso Discurso Aos Eleitores de Bristol, refuta as instruções imperativas do mandato em trecho célebre da Ciência Política e do Direito Constitucional:

(...) A opinião dos eleitores é uma opinião de peso e respeito que um representante deve sempre se alegrar por ouvir e sempre examinar com a máxima atenção, mas as instruções imperativas, os mandatos que o deputado está obrigado, de maneira cega e implícita, a obedecer, votar e defender, ainda que sejam contrárias às convicções mais claras de seu juízo e de sua consciência, são coisas totalmente desconhecidas nas leis do país e surgem de uma interpretação fundamentalmente equivocada de toda ordem e respeito à nossa Constituição.

O Parlamento não é um congresso de embaixadores que defendem interesses distintos e hostis, interesses que cada um de seus membros deve sustentar, como agente e advogado, contra outros agentes e advogados, mas uma assembléia legislativa de uma nação, com um interesse: o da totalidade, onde o que deve valer não são os interesses e preconceitos locais, mas o bem geral que resulta da razão geral como um todo. Elegei um deputado, mas quando o haveis escolhido, ele não é um deputado por Bristol e sim um membro do Parlamento. Se o eleitor tiver um interesse ou formar uma opinião precipitada, que claramente se oponham ao bem-estar real do resto da comunidade, o deputado, no assunto em pauta, deve se abster, como os demais, de qualquer gestão para levá-lo a cabo. (...)

Somos agora deputados por uma rica cidade comercial cujos interesses são variados, multiformes e intrincados. Somos deputados de uma grande nação que, contudo, não é senão parte de um grande império, expandido, por nossa virtude e nosso destino, aos limites mais longínquos do Oriente e do Ocidente. Todos esses vastos interesses devem ser considerados, comparados e, se possível, reconciliados. Somos deputados de uma grande e antiga monarquia e devemos conservar religiosamente os verdadeiros direitos legais do soberano que formam a pedra fundamental que une o nobre e bem construído arco de nosso império à nossa Constituição (....). ${ }^{44}$

Embora não tenha sido sistemático e coerente em seus escritos e não tenha apresentado uma teoria consistente acerca da representação ${ }^{45}$, verifica-se claramente, na visão de Burke, que o deputado não mais poderia representar os interesses individuais dos eleitores e sim o interesse da nação como um todo.

Conquanto Burke não tenha sido o primeiro a rejeitar a ideia do mandato imperativo, o seu Discurso aos Eleitores de Bristol é um dos registros mais emblemáticos sobre o tema.

\footnotetext{
${ }^{44}$ BURKE, Edmund. Discurso a los electores de Bristol. In: Textos políticos. Versión española e introducción de Vicente Herrero. México: Fondo de Cultura Económica, 1942. p. 312-313. Cf. também Discurso aos eleitores de Bristol. Tradução de Cid Knipel Moreira in Os clássicos da política. $2^{\circ}$ volume. Organizador Francisco C. Weffort. São Paulo, Ática, 2001, pp. 29-30.

${ }^{45}$ PITKIN, Hannah Fenichel. op. cit., p. 185.
} 
Hanna Pitkin ${ }^{46}$, ao comentar os escritos de Burke, observa que dois conceitos de representação podem ser encontrados nos textos do parlamentar inglês. O primeiro, no sentido de que haveria uma aristocracia de virtude e sabedoria governando para o bem da nação inteira. Cada membro do parlamento, que faz parte de uma elite, age e decide em prol do interesse nacional. O Segundo conceito, não aceito por todos, é o da representação virtual, no sentido de que aqueles que são eleitos por poucos supõe-se que a todos representa.

Embora sua concepção de representação não seja consistente em termos teóricos, as palavras de Burke são comumente lembradas como um marco da quebra do vínculo entre representante e representado, e como referência sobre o mandato livre. $\mathrm{O}$ parlamentar possui autonomia e representa interesses nacionais e não mais os interesses locais e individuais de cada representado. O parlamentar é livre para decidir sobre temas maiores, não sendo mais concebível a representação delegada, imperativa.

É importante registrar que essa polêmica sobre quem é representado, que, de certa forma, foi posta em destaque por Burke, existe até hoje e é um dos grandes dilemas sobre a representação política.

O tema "sentir-se representado", apesar dos séculos que já se passaram, enseja ainda muita discussão e, no Brasil, principalmente pelo fato de vivenciarmos um Estado Democrático recente, existe um sentimento geral sobre a necessidade de aproximação entre os eleitores e os eleitos.

\subsubsection{A representação política na França do Século XVIII}

\subsubsection{A Revolução Francesa}

Com a Revolução Francesa consolida-se a extinção do mandato imperativo e a consagração do mandato representativo.

No continente europeu o processo de transformação da sociedade medieval para a sociedade moderna foi diferente do processo inglês. Consequentemente, os modelos representativos, francês e inglês, foram também distintos. ${ }^{47}$

\footnotetext{
${ }^{46}$ PITKIN, Hannah Fenichel. op. cit., p. 188-192.

${ }^{47}$ Darcy Azambuja ensina que "a evolução política do feudalismo inglês terminou com resultados inteiramente opostos à do feudalismo francês e continental. Enquanto no Continente o regime feudal produzia a monarquia absoluta, na Inglaterra engendrava a monarquia limitada, o regime representativo"
} 
A sociedade francesa, no início do século XVIII, dividia-se basicamente em três ordens sociais: a nobreza, o clero e o restante da população. A nobreza e o clero representavam apenas dois por cento da população e desfrutavam de vários privilégios instituídos pela própria ordem jurídica vigente à época. Os nobres ocupavam os principais cargos do governo, do exército e da igreja, não recolhiam tributos e possuíam cerca de um terço das terras do território francês. $\mathrm{O}$ alto clero compartilhava dos mesmos privilégios e regalias da nobreza e comandava a censura e administração das escolas. Havia diferenças dentro da própria nobreza e do clero. Nem todos os nobres eram iguais, pois existiam distinções de dignidade entre os nobres de espada (pertencentes às antigas famílias aristocratas da França) e os novos nobres (burgueses agraciados pelo monarca com títulos de nobreza). O restante da sociedade era composto por burgueses, pelo campesinato e pelos trabalhadores urbanos, que formariam o terceiro estado. ${ }^{48}$

Dentro desse quadro havia uma forte resistência da nobreza à ascensão social da classe burguesa. Havia, portanto, uma franca hostilidade entre essas duas classes. Frustrados com essa situação e pelos abusos do monarca, a classe burguesa começou a reagir e a se indispor contra o sistema existente. $O$ terceiro estado passa a exigir a valorização do talento em vez da valorização da origem social, o estabelecimento de um Poder Legislativo que legislasse em prol da Nação e não em favor de uma minoria. ${ }^{49}$

Nesse contexto, Eric J. Hobsbawn ${ }^{50}$ faz um preciso relato de como o Terceiro Estado realizou sua primeira conquista revolucionária:

Visto que os camponeses e os trabalhadores pobres eram analfabetos, politicamente simples ou imaturos, e o processo de eleição, indireto, 610 homens foram eleitos para representar o Terceiro Estado. A maioria da assembléia era de advogados que desempenhavam um papel econômico

(AZAMBUJA, Darcy. Teoria geral do Estado. 35. ed. São Paulo: Globo, 1996. p. 263). André Hauriou observa que, com a conquista normanda, o feudalismo passa a ser implantado na Inglaterra de forma intensa e sistemática, de tal modo que, desde o início, sua organização foi regular e hierárquica. O poder real forte dominava a organização feudal. Na França, ao contrário, o feudalismo se implantou espontaneamente, no meio da desorganização. A monarquia dos Capetos, no início, encontrava-se quase despojada das prerrogativas reais, frente a uma nobreza forte. Essa diferença resultaria, paradoxalmente, benéfica para os ingleses. Na Inglaterra, a nobreza feudal e a classe média, ao possuírem um interesse comum em sua luta contra o poder real que lhes oprimia, se uniram para limitar as prerrogativas do rei. Por outro lado, na França, a classe média mais oprimida (mais pelos nobres do que pelo rei) passa a ter interesse comum com a coroa para derrubar a nobreza feudal. O resultado disso, após vários séculos, foi o exagerado incremento do poder real, que constituiu a grande crise da monarquia absoluta francesa. (HAURIOU, André. Derecho constitucional e instituciones políticas. Traducción castellana, adaptación y apéndice a cargo de José Antonio Gonzáles Casanova. Barcelona: Ediciones Ariel, 1971. p. 227-228).

${ }^{48}$ PERRY, Marvin. op. cit., p. 319-326.

${ }^{49}$ Id. Ibid., p. 323-324; 330-331.

${ }^{50}$ HOBSBAWN, Eric J. A era das revoluções. Tradução de Maria Tereza Lopes e Marcos Penchel. 23. ed. Rio de Janeiro: Paz e Terra, 1977. p. 92. 
importante na França provinciana: cerca de 100 representantes eram capitalistas e homens de negócios. O Terceiro Estado tinha lutado acirradamente, e com sucesso, para obter uma representação tão grande quanto a da nobreza e a do clero juntas, uma ambição moderada para um grupo que oficialmente representava $95 \%$ do povo. E agora lutava com igual determinação pelo direito de explorar sua maioria potencial de votos, transformando os Estados Gerais numa assembléia de deputados que votariam individualmente, ao contrário do corpo feudal tradicional que deliberava e votava por "ordens" ou "estados", uma situação em que a nobreza e o clero podiam sempre derrotar o Terceiro Estado. Foi aí que se deu a primeira vitória revolucionária. ${ }^{51}$

Foi por intermédio do novo panorama da representação política que o Terceiro

Estado se afirmou como classe social. Com as idéias revolucionárias, consolida-se na França a extinção do mandato imperativo e a consagração definitiva do mandato representativo.

\subsubsection{A nação como titular da soberania}

Com a Revolução Francesa de 1.789 surge uma nova noção de Estado. O indivíduo torna-se cidadão com direitos e deveres, e a atividade governamental passa a se fundamentar nas leis. A titularidade da soberania estatal passa a pertencer à nação ${ }^{52}$,

\footnotetext{
${ }^{51}$ No mesmo sentido são as palavras de Jorge Grespan, quando se refere aos embates acalorados ocorridos nos Estados Gerais: "O conflito começou já na definição do peso de cada ordem nos Estados Gerais. A Assembléia dos Notáveis havia estabelecido que as três teriam o mesmo número de deputados e que o voto seria por categoria, como ocorrera da última vez, em 1614. Deste modo, a nobreza e o clero unidos sempre derrotariam as reivindicações do terceiro estado. Passados quase dois séculos, contudo, a sociedade francesa havia mudado muito. A importância da burguesia era agora incomparavelmente maior e ela não se sujeitava a ter a mesma representação que grupos tão minoritários quanto a aristocracia e o clero. Surgem protestos e panfletos por todo o país, entre os quais o de Emmanuel Siéyès (1748-1836), O que é o Terceiro Estado, publicado em janeiro de 1789 com enorme repercussão: afirmando que essa ordem abrangia 96\% da nação, Siéyès pleiteia que ela tivesse uma quantidade proporcional de representantes. Luís XVI resolve conciliar as posições e concorda em dobrar o número de deputados do terceiro estado: seriam cerca de 600, para 300 de cada uma das outras duas. Com isso, porém, aparece um novo problema: de nada adiantava ter mais representantes se o voto fosse por categoria. Assim, quando se instala os Estados Gerais, em 5 de maio de 1789, o terceiro estado propõe o voto por cabeça, e ainda mais, que as três ordens trabalhem conjuntamente, numa plenária. É claro que isso não foi aceito nem pelo rei. Entretanto, as duas ordens privilegiadas não eram homogêneas. Especialmente entre os representantes da Igreja havia muitos deputados oriundos do baixo clero que se identificavam com o povo estavam dispostos a reunir-se aos demais. Mesmo alguns membros do alto clero pensavam deste modo, e a eles se juntava uma pequena parte da nobreza, considerada 'liberal'. Depois de algumas semanas de embates acalorados inteiramente dedicados a essa questão, vence a maioria, e a partir de 24 de junho as três ordens se unem numa só assembléia, que logo depois se declara constituinte". (GRESPAN, Jorge Luis da Silva. Revolução Francesa e iluminismo: a crítica radical do "Espírito das Luzes". Críticos, céticos e românticos: uma nova ordem social. 1. ed. São Paulo: Contexto, 2008. p. 80-82.)

${ }^{52}$ Certamente Rousseau não teria concordado com a tese sobre a representação da nação. O filósofo que influenciou os revolucionários com suas idéias sobre liberdade e igualdade, e que faleceu mais de uma década antes da revolução, fez contundentes críticas à representação em passagem célebre do Contrato
} 
consoante estabeleceu a Declaração dos Direitos dos Homens e dos Cidadãos. ${ }^{53}$ Em contraposição ao mandato imperativo do antigo regime, consagra-se a idéia de que a titularidade da soberania caberia à nação.

Foi Siéyès, em sua obra Quest-ce Que Le Tercer État ${ }^{54}$, marco da Revolução Francesa, que desenvolveu a teoria da representação da nação de maneira contundente, defendendo os direitos políticos do Terceiro Estado, da classe burguesa emergente. ${ }^{55}$

Monica Herman Salem Caggiano comenta a influência de Siéyès sobre o fenômeno da representação política:

Sob o impacto das teorias lançadas pelo abade Siéyes, o mandato político foi contemplado com nuanças representativas de nível nacional. Insuflado pela tese da soberania nacional, passa o mandato como pertencente à nação e o representante, nessa qualidade, conquista sua liberdade de

Social, in verbis: “A soberania não pode ser representada pela mesma razão que não pode ser alienada; consiste essencialmente na vontade geral, e a vontade geral não se representa: ou é a mesma, ou é outra não existe meio-termo. Os deputados do povo não são, pois, nem podem ser os seus representantes; são simplesmente comissários, e nada podem concluir definitivamente. Toda lei que o povo não tenha ratificado diretamente é nula, não é uma lei”. (ROUSSEAU, Jean-Jacques. O contrato social. Tradução: Antonio de Pádua Danesi. 3. ed. São Paulo: Martins Fontes, 1996. p. 114.)

${ }^{53}$ Declaração dos Direitos dos Homens e dos Cidadãos. Art. $3^{o}$. A fonte de toda soberania reside essencialmente na nação. Nenhum indivíduo ou grupo de indivíduos poderá exercer qualquer autoridade que não emane diretamente da nação.

${ }^{54}$ Passagem simbólica da obra de Siéyès é aquela em que o mencionado autor preconiza que os deputados do Terceiro Estado devem ter o mesmo número de representantes das ordens privilegiadas: "quando si quiere decidir uma cuestión como esta no hay que contentarse, según se hace muy a menudo, com expresar el deseo, o la voluntad, o el uso com razones; hay que remontarse a los principios. Los derechos políticos, como los derechos civiles, deben corresponder a La cualidad de ciudadano. Esta propriedad legal e la misma para todos, sin consideración al más o menos de propriedad real de cada individuo pueda componer su fortuna o su bein. Toda ciudadano que reúne las condiciones determinadas para ser elector tiene derecho a hacerse representar, y su representación no puede ser uma fración de La representación de outro. Este derecho es uno; todos lo ejercem por igual, como todos están protegidos igualmente por La ley que han concurrido a hacer. ¿ Como puede sostenerse, de um lado, que la ley es la expresión de La voluntad general, es decir, de La mayoria, y pretender ao mismo tiempo que diez voluntades particulares? $i$ No equivale eso a exponerse a dejar que La minoria haaga La ley, lo que es contrario evidentemente a La naturaleza de las cosas? (SIÉYÈS, Emmanuel. Que es el tercero Estado? Introdución, tradución y notas de Francisco Ayala. Madrid: Aguilar Ediciones, 1973. p. 37-38).

${ }^{55}$ Segundo Bernard Manin, para Siéyès, "a representação não é uma versão imperfeita da democracia direta, decorrente de necessidades práticas; é uma forma de governo totalmente diferente e preferível. Siéyès considera o governo representativo como um sistema superior, não tanto por redundar em um processo decisório mais racional e menos passional, quanto por constituir uma forma política mais adequada às sociedades mercantis modernas, onde as pessoas estão permanentemente ocupadas na produção e troca de riquezas. Nessas sociedades, observa Siéyès. Os cidadãos não dispõem mais do tempo necessário para se ocupar constantemente dos negócios públicos. Sendo assim, eles precisam confiar o governo, por intermédio de eleições, a indivíduos que dediquem todo o seu tempo a essa tarefa. Acima, de tudo, Siéyès vê na representação uma aplicação da divisão do trabalho à esfera da política, princípio este que ele acredita ser um fator essencial para o progresso social (...) Ele observa ainda que não é função dos representantes agir como meros transmissores da vontade dos eleitores. É portanto, incontestável, diz ele, que os deputados não estão na Assembléia Nacional para afirmar vontades já formuladas por seus eleitores, mas para deliberar e votar livremente, de acordo com o juízo que façam no momento e esclarecidos por toadas as luzes que a Assembléia possa lhes proporcionar" (MANIN, Bernard. As metamorfoses do governo representativo. Tradução de Vera Pereira. <HTTP://www.anpocs.org.br/portal/publicacoes/rbcs29_01>. Acesso em: 02 dez. 2008). 
deliberação de acordo com a sua própria consciência e sempre em prol dos interesses maiores da nação. Nem mesmo o marcante efeito da figura do partido político, em ascensão a partir da segunda metade do século $\mathrm{XX}$, retirou a influência da doutrina de Siéyès, no tocante à natureza da representação política. ${ }^{56}$

A ideia de que o deputado representava a nação presente na obra de Siéyès já se encontrava presente na Inglaterra no começo do Século XVII e também, de certa forma, em Montesquieu ${ }^{57}$. Porém, com a Declaração dos Direitos dos Homens e dos Cidadãos e, posteriormente, em 1791, com a Constituição Francesa ${ }^{58}$, tal concepção passa a ser princípio da ordem jurídica desse país, afastando-se, assim, de forma definitiva, a prática do mandato imperativo na França. ${ }^{59}$

Sobre o tema, Giovanni Sartori afirmou que é importante compreender a novidade trazida com essa nova concepção acerca da titularidade da soberania. A fórmula da soberania nacional é completamente distinta da soberania popular porque nação não é povo, a soberania da nação não é a soberania democrática. A fórmula da soberania nacional significa que a vontade da nação pré-existe à vontade dos representantes e que a vontade destes é a vontade da nação. ${ }^{60}$

${ }^{56}$ CAGGIANO, Monica Herman Salem. Direito parlamentar e direito eleitoral. Barueri, SP: Manole, 2004. p. 14.

${ }^{57}$ Montesquieu, assim como Burke, entendia que o povo não possuía capacidade para discutir os assuntos de natureza política. Além disso, também entendia que não havia necessidade de os representantes receberem instruções particulares sobre cada assunto específico, conforme consta do seguinte trecho de sua obra $O$ Espírito das Leis: "A grande vantagem dos representantes é que eles são capazes de discutir os assuntos. O povo não é nem um pouco capaz disto, o que constitui um dos inconvenientes da democracia. Não é necessário que os representantes, que receberam daqueles que os escolheram uma instrução geral, recebam outra particular sobre cada assunto, como se pratica nas dietas da Alemanha. É verdade que, desta maneira a palavra dos deputados seria a melhor expressão da voz da nação; mas isto provocaria demoras infinitas, tornaria cada deputado o senhor de todos os outros assuntos, e nas ocasiões mais urgentes, toda a força da nação poderia ser retida por um capricho (MONTESQUIEU, Charles Secondat, Baron de. O Espírito das leis. Tradução de Cristina Murachco. São Paulo: Martins Fontes, 1996. Livro 11, cap. 6, p. 171).

${ }^{58}$ Constituição Francesa. Título III, Capítulo I, Seção III, art. $7^{\circ}$ : “Os representantes não serão representantes de cada Departamento, mas de toda a Nação, não podendo nenhum Departamento conferir qualquer mandato".

${ }^{59}$ Muito embora os ingleses já falassem em mandato livre antes dos franceses, é interessante destacar o fato, curioso, de que, ainda no século XIX, na Inglaterra, especificamente em Londres, existiam associações que aglutinavam grande número de eleitores e que governavam em certas localidades da cidade, impondo o mandato imperativo aos representantes, cuja eleição dependia de seus apoios, conforme previsões contidas na chamada Resolução de Londres, de 1832 (DALLARI, Dalmo de Abreu. op. cit., p. 158).

${ }^{60}$ SARTORI, Giovanni. op. cit., p. 20-21. 
Para Carré de Malberg, a partir daí, o termo representação não designa mais apenas a relação entre deputado e mandantes. Ao representante é concedido um poder de querer e decidir pela nação. ${ }^{61}$

Vale registrar que, na França, mesmo diante desse novo panorama, Robespierre, em 10 de maio de 1793, proferiu discurso na Convenção em defesa do mandato imperativo, afirmando veementemente que gostaria que todos os funcionários públicos nomeados pelo povo pudessem ser demitidos pelo próprio povo, sem qualquer outro motivo senão o direito imprescritível que lhe pertence de revogar seus mandatários. ${ }^{62}$

\subsubsection{A teoria do mandato representativo e a teoria da duplicidade}

Quando se diz que a nação é representada e não os eleitores em suas circunscrições, evoca-se a teoria do mandato representativo, que teve sua origem nas idéias de Blackstone, Burke e Siéyès, e principalmente deste último, pois, por sua influência, o mandato pertencente à nação foi erigido a princípio da ordem constitucional francesa.

Segundo essa teoria, o representante recebe um mandato de toda a nação e não de seus eleitores ou do distrito eleitoral. Não se fala mais em mandato de direito privado, irrevogabilidade e prestação de contas. O representante torna-se independente de seus eleitores e sua atuação parlamentar e votações seguem a sua própria consciência, podendo o representante, inclusive, votar contra a vontade do eleitorado. Representa-se a nação como um todo, inclusive a parte do eleitorado que tenha sido hostil com o representante. $\mathrm{O}$ mandato torna-se coletivo em razão da indivisibilidade da soberania, irrevogável e a essência da representação política passa a consistir no querer da nação. A independência dos representantes passa a ser assegurada pelas imunidades parlamentares e pela inviolabilidade no exercício do mandato, pelas opiniões, palavras e votos, significando isso que os representantes não podem ser responsabilizados pelo modo pelo qual exercem o seu mandato. ${ }^{63}$

Dessas concepções teóricas advindas da Inglaterra e da França, tidas como liberais, às quais os representantes se fizeram depositários da soberania, surge também a

\footnotetext{
${ }^{61}$ MALBERG, Carré de apud SARTORI, Giovanni. op. cit., p. 22.

${ }^{62}$ ROBESPIERRE, Maximilen de apud HAURIOU, André. Le droit de revocatión populaire. Revue Politique et Parlementaire. Paris, t. 70, p. 70, juil./sept. 1924.

${ }^{63}$ TEIXEIRA, J. H. Meirelles. op. cit., p. 494-495.
} 
doutrina da duplicidade, segundo a qual haveria duas vontades distintas na representação, a do eleitor, uma vontade menor e efêmera, restrita à operação eleitoral e a vontade do eleito ou representante, autônoma, advinda desse procedimento eleitoral. ${ }^{64}$

\subsubsection{A Representação Política nos Estados Unidos}

\subsubsection{As instruções para os representantes}

Segundo as lições de Thomas E. Cronin ${ }^{65}$, nas décadas de 1760 e 1770, os colonos norte-americanos, apesar de se encontrarem vinculados à Coroa Britânica, não escolhiam representantes para a Câmara dos Comuns. Quando tributos passaram a ser cobrados sobre o consumo de chá nas colônias e sobre a guerra, os colonos protestaram pelo fim do pagamento de impostos sem representação. O tema representação, a partir daí, passa a chamar a atenção dos colonos e a ideia do autogoverno passa a ser a mola propulsora da Revolução Norte-americana.

Diante desse contexto, para convencer os colonos de que eles não precisavam necessariamente votar no Parlamento Inglês para serem representados, as lideranças inglesas passaram a se utilizar dos argumentos da representação virtual, ideia essa defendida por Burke, segundo o qual o povo inglês, apesar das diferenças sociais e geográficas, era um povo homogêneo com interesses em comum e que os assuntos que afetassem os não-eleitores afetariam também os eleitores e o que afetasse os ingleses em qualquer lugar do império, em última análise, afetaria qualquer cidadão inglês. ${ }^{66}$

Ainda, de acordo com as observações de Cronin, os colonos perceberam que havia chegado a hora de criar o seu próprio governo e os seus próprios interesses passariam a ser o ponto central de seus objetivos. O governo representativo desenvolve-se e junto com ele as discussões sobre como seus representantes deveriam ser instruídos. Muitas colônias e Estados, dentre eles Massachusetts, Vermont, Pensilvânia e Carolina do Norte estipularam em algum momento como seus representantes deveriam votar e, dentro dessa

\footnotetext{
${ }^{64}$ BONAVIDES, Paulo. Ciência política. 10. ed. rev. e atual. São Paulo, Malheiros Ed., 1999. p. 204.

${ }^{65}$ CRONIN, Thomas E. Direct democracy: the politics of the initiative, referendum and recall. Cambridge MA: Harvard University Press, 1999. p. 22-23.

${ }^{66}$ Id. Ibid., p. 23.
} 
abordagem, havia a crença de que o direito de votar e de ser representado configurava um meio de se garantir a liberdade. ${ }^{67}$

A prática das instruções dos eleitores foi muito disseminada pelos Estados Unidos, desde o período colonial até os dez primeiros anos após a declaração da independência. O estado da Nova Inglaterra, entre outros, chegou a incluir em sua Constituição o direito de instrução. Cogitou-se, inclusive, quando se discutia o Bill of Rights, acrescentar à Primeira Emenda (que trata da liberdade de expressão e de religião) o direito de dar instruções aos representantes. Entretanto, a proposta foi rejeitada. Os eleitores permaneceriam livres para dar instruções, porém, estas não teriam qualquer suporte legal. ${ }^{68}$

\subsubsection{O governo representativo norte-americano}

Com a evolução do governo federativo, as instruções deixaram de ter valor, em termos nacionais, para a política norte-americana. No final da década de 1780, com Madison e Hamilton, a questão das instruções vinculantes passa a ser contestada. A preocupação passa a ser com a res publica para que os interesses da nação, a longo prazo, não fossem continuamente sacrificados por vontades locais. ${ }^{69}$

Hanna Pitkin ${ }^{70}$ escreve que, nos artigos federalistas, Alexander Hamilton, John Jay e James Madison, falam em governo representativo como um modelo substituto da democracia direta, uma vez que a reunião de um grande número de pessoas e um único lugar seria impossível. A representação é concebida como um substituto para o encontro pessoal dos cidadãos, mas esse modelo não era considerado um substituto menor. Os Federalistas admitiam ainda a existência de algo maior e mais objetivo, que é o bem público e, assim, a representação passa a ser mais relevante do que a democracia direta porque pode assegurar a res publica sem a distração de vários interesses particulares conflitantes (facções).

\footnotetext{
${ }^{67}$ CRONIN, Thomas E. op. cit., p. 23-24.

${ }^{68}$ MANIN, Bernard. op. cit.; Id. The principles of representative government. Cambridge: Cambridge University Press, 1997. p. 164.

${ }^{69}$ CRONIN, Thomas E. op. cit., p. 24-25.

${ }^{70}$ PITKIN, Hannah Fenichel. Representação: palavras, instituições e idéias. Lua Nova, n. 67. 2006. Disponível em: <http://www.scielo.br/pdf/ln/n67/a03n67.pdf>. Acesso em: 02 dez. 2008.
} 
Cronin $^{71}$ assevera que Burke influenciou os fundadores da república norteamericana, em especial James Madison e John Adams. No final da década de 1780, Madison chegou a desenvolver uma concepção abrangente de representação e de governo republicano, e a ideia pró-independência resultante dessa concepção ainda hoje é considerada a visão predominante sobre o papel dos representantes. ${ }^{72}$ Pelo aspecto prático, os representantes, principalmente nos estados maiores e no Congresso, raramente consultam suas bases antes de votar as propostas e medidas governamentais. Além disso, na visão dos formadores da República havia uma confiança no governo equilibrado, nos sistemas de freios e contrapesos. Cada um dos departamentos do poder (Executivo, Legislativo e Judiciário) foi estabelecido, cada qual à sua maneira, para representar o povo. Portanto, o sistema todo seria representativo.

\section{Gordon S. Wood observa que:}

Já na altura de 1787-1788 a democracia acabara sendo identificada por alguns norte-americanos simplesmente como um governo representativo emanado do povo. Em outras palavras, republicanismo e democracia estavam sendo igualados. As Câmaras de representantes perderam sua conexão exclusiva com o povo. Representação identificava-se agora simplesmente com eleição. Assim, todas as autoridades eleitas, e, no caso de algumas, mesmo aquelas não eleitas, como os juízes, eram consideradas, de certo modo, "representantes" do povo. Consequientemente, as idéias clássicas mais antigas de democracia e governo misto que remontavam a Aristóteles se tornaram irrelevantes na descrição do novo sistema político norte-americano. A democracia tornou-se um rótulo genérico para todo o Governo norte-americano. ${ }^{73}$

\footnotetext{
${ }^{71}$ CRONIN, Thomas E. op. cit., p. 28.

${ }^{72}$ Dalmo de Abreu Dallari ensina que "Ao se organizar o governo do novo Estado norte-americano, muitos queriam que ele tivesse caráter federal, isto é, que fosse constituído por representantes dos novos Estados, reunidos em federação. Outros sustentavam que o governo deveria ter caráter nacional, ou seja, que fosse representante da nação norte-americana tomada em seu conjunto. De acordo com as idéias republicanas e democráticas, o povo é que deveria governar, devendo fazê-lo através de representantes, por motivos de ordem prática. A conciliação dessas correntes se deu precisamente na formação do órgão do Poder Legislativo. Este foi totalmente entregue a um Congresso, respeitando a tradição, mas o Congresso foi composto de duas casas: o Senado e a Câmara dos Representantes. O Senado foi criado com a característica de ramo federal, como representante dos Estados-membros, estabelecendo-se que o Legislativo de cada Estado-membro elegeria dois representantes e que a cada dois anos se faria a renovação de um terço da representação. Em 1913 os Senadores passaram a ser eleitos diretamente pelo povo, por força de uma Emenda Constitucional, mantendo-se, entretanto, suas demais características e sobretudo suas competências, através das quais se verifica claramente que os Senadores têm a função primordial de assegurar a participação dos respectivos Estados nas decisões políticas do governo. Deu-se à Câmara de Representantes a condição de ramo nacional, representativo do povo, estabelecendo-se que o número de representantes originários de cada Estado será proporcional à população desse mesmo Estado. E desde início se deu ao povo a atribuição de eleger os membros da Câmara dos Representantes, dando-se a estes um mandato de apenas dois anos, para que a renovação freqüente assegure maior representatividade." (DALLARI, Dalmo de Abreu. O Estado Federal. São Paulo: Ática, 1986. p. 31-32).

${ }^{73}$ WOOD, Gordon S. A democracia e a Constituição. In: GOLDWIN, Robert A.; SCHAMBRA, William A. (Eds.). A Constituição norte americana. Prefácio de Paulo Bonavides. Rio de Janeiro: Forense Universitária, 1986. p. 206.
} 
Apesar dessas concepções que influenciaram a formação do governo norteamericano, principalmente os Estados do sul continuaram a exigir que seus senadores votassem em conformidade com a opinião da legislatura estadual. A partir de 1840 essa

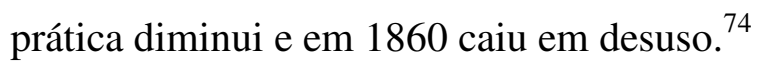

No final do século XIX e começo do século XX passa-se a discutir os problemas da representação e, paralelamente, os movimentos populista e progressista, nos Estados Unidos, aparecem acenando com os mecanismos de democracia semidireta para controlar a atuação dos agentes públicos e, de certa forma, calibrar as deficiências da representação política, principalmente nos níveis regionais e locais.

\subsubsection{A Representação Política no Século XIX}

\subsubsection{Os questionamentos sobre a representação política}

No Século XIX, com o crescimento da população, a ideia de Estado-Nação e ampliação do direito de voto surge a noção de que deve haver substância na representação, de que os representantes devem ter, de algum modo, uma espécie de amostra da população a quem representam. Surge a questão da representação das minorias nos parlamentos. A representação passa a ter um significado descritivo no sentido de que deve existir elementos da população presentes no parlamento ou assembleia. ${ }^{75}$

A par disso, com a ascensão política do proletariado, surge nesse mesmo século, na França e na Inglaterra, a teoria da representação profissional, na qual se pensou em substituir a representação política pela representação das categorias profissionais. No entanto, por questões de ordem prática essa ideia não foi levada adiante, resultando disso, porém, alguns resultados positivos, a exemplo do reconhecimento do poder normativo das organizações sindicais. $^{76}$

\footnotetext{
${ }^{74}$ CRONIN, Thomas E. op. cit., p. 26.

${ }^{75}$ LAMOUNIER, Bolívar. Reflexões filosóficas e considerações políticas sobre os modelos de representação: uma visão comparada. In: SEMINÁRIO SOBRE MODELOS ALTERNATIVOS DE REPRESENTAÇÃO POLÍTICA NO BRASIL, Painel II. Brasília: Ed. da UnB, 1981. p. 105-106.

${ }^{76}$ DALLARI, Dalmo de Abreu. Elementos de teoria geral do Estado, cit., p. 169-176.
} 


\subsubsection{A teoria dos órgãos}

Na Alemanha, ainda no Século XIX, por intermédio de Gierke, Jellinek e Laband surge a teoria dos órgãos do Estado, segundo a qual todas as coletividades organizadas compõem uma pessoa jurídica e, por essa razão, devem possuir uma vontade e os meios para exercê-la. Como a vontade parte das pessoas, a pessoa jurídica confere, pela sua própria organização, a determinados indivíduos, a função de exprimir a vontade coletiva. Esses indivíduos constituem os órgãos da pessoa coletiva, os quais podem também ser coletivos. O mandato supõe sempre duas pessoas e o órgão jurídico, ao contrário, supõe a existência de uma só pessoa, a coletividade organizada, que quer e age por seus órgãos. ${ }^{77}$

Essa teoria que influenciou Carré de Malberg e Bigne de Villeneuve possuía a vantagem de afastar as dificuldades do regime representativo, principalmente no que dizia respeito à relação entre eleitores e eleitos, mas, por outro lado, apresentava como aspecto negativo a criação do absolutismo de Estado, numa espécie de retrocesso às teorias do passado, sem estabelecer a diferença entre a vontade do Estado e a dos governantes. ${ }^{78}$

\subsubsection{O governo representativo de Stuart Mill}

Stuart Mill vê como o único governo ideal aquele em que todo o povo pudesse participar, mesmo nas funções públicas mais modestas, e que seria desejável, como situação extrema, a admissão de todos a uma parte do poder soberano do Estado. Porém, observa que é impossível a participação pessoal de todos nos negócios públicos (salvo em pequenos e determinados assuntos) e que, por essa razão, o governo representativo seria o tipo ideal de governo. Além disso, a Constituição deveria reconhecer garantias para preservar o governo representativo com a instituição da representação das minorias, soberania popular, igualdade política dos cidadãos e princípio da proporcionalidade. ${ }^{79}$

Percebe-se em Stuart Mill a mesma preocupação constante dos federalistas Hamilton, Jay e Madison com relação à impossibilidade prática de existir o governo direto do povo, o que justifica a necessidade de representantes. No entanto, em Mill, a representação apresenta outro conteúdo, uma preocupação relacionada ao seu

\footnotetext{
${ }^{77}$ AZAMBUJA, Darcy. op. cit., p. 272-273.

${ }^{78}$ Id., loc. cit.

${ }^{79}$ MILL, John Stuart. O governo representativo. Tradução: E. Jacy Monteiro. 2. ed. São Paulo: Ibrasa, 1993. p. 49 e 159.
} 
funcionamento, ao seu aperfeiçoamento e principalmente com relação à representação de todos, inclusive das minorias.

\subsubsection{A ampliação do direito de sufrágio}

O historiador Eric J. Hobsbawn apresenta uma nítida fotografia sobre a ampliação do direito de voto e a democratização dos Estados no final do Século XIX e início do Século XX, traçando um panorama detalhado dessa época:

Após 1879, tornou-se cada vez mais claro que a democratização da política dos Estados era inteiramente inevitável. As massas marchariam para o palco da política, quer isso agradasse ou não os governantes. Foi o que realmente aconteceu. Sistemas eleitorais baseados em amplo direito ao voto e às vezes, teoricamente, até no sufrágio universal masculino, existiam já na França e na Alemanha, em 1870 (pelo menos para o parlamento nacional alemão) bem como na Suíça e na Dinamarca. Na Inglaterra, as leis da reforma de 1867 e 1883 quase duplicaram o eleitorado, que se elevou de 8 a $29 \%$ para os homens com mais de vinte anos. A Bélgica democratizou estes direitos em 1894, após uma greve geral realizada por essa reforma (o aumento foi de 3,9 para 37,3\%, para a população adulta); a Noruega dobrou essas cifras em 1898 (de 16,6 para $34,8 \%)$. Na Finlândia, uma democracia extensiva única (76\% dos adultos) surgiu com a revolução de 1905. Na Suécia, o eleitorado dobrou em 1908, alcançando o nível do da Noruega. A metade austríaca do império dos Habsburgo recebeu o sufrágio universal em 1907, e a Itália em 1913. Fora d Europa, os EUA, a Austrália e a Nova Zelândia já eram, é claro, democráticos, e a Argentina seguiu-lhes o exemplo em 1912. Segundo padrões mais recentes, essa democratização ainda era incompleta - o eleitorado comum, sob sufrágio universal, era de 30 a $40 \%$ da população adulta - mas deve-se notar que até o voto feminino já era mais do que um slogan. Havia sido introduzido nas margens dos territórios dos colonizadores brancos, na década de 1880 - No Wyoming (EUA), na Nova Zelândia e na Austrália do Sul - e nas democracias da Finlândia e Noruega, entre 1905 e $1015 .^{80}$

Com o aumento da participação popular por meio do voto promovendo a escolha dos representantes, o aparecimento dos partidos de massa e de grandes organizações sindicais e econômicas, e com a expansão das atividades e burocratização do governo, as controvérsias sobre a representação se intensificam.

No Século XIX, a discussão passa a girar em torno da eficiência da representação, passa-se a discutir a seleção e as formas para controlar as atividades dos representantes.

\footnotetext{
${ }^{80}$ HOBSBAWN, Eric J. A era dos impérios: 1875-1914. Traduçao de Sieni Maria campos e Yolanda Steidel
} de Toledo. 11. ed. Rio de Janeiro: Paz e Terra, 2007. p. 127. 


\subsubsection{Os partidos políticos}

No início do século XIX, os partidos políticos se afirmam como instrumentos eficientes da opinião pública. As principais tendências no Estado passam a exercer influência no governo e o partido se torna um veículo da representação política. Em razão disso, as agremiações se multiplicam, apresentando diversas características. ${ }^{81}$

A partir da segunda metade do século XIX, os partidos políticos passam a ser considerados como um componente essencial da democracia representativa e os programas políticos passam a ser um dos principais instrumentos da competição eleitoral no final do século. $^{82}$

Maurice Duverger relata que, em 1850, apenas os Estados Unidos da América conheciam os partidos políticos, no sentido moderno do termo. Em 1950, ou seja, cem anos depois, os partidos funcionavam na maioria das nações civilizadas. Nas palavras do próprio autor: "Em seu conjunto, o desenvolvimento dos partidos parece associado ao da democracia, isto é, à extensão do sufrágio popular e das prerrogativas parlamentares. Quanto mais as assembléias políticas vêem desenvolver suas funções e independência, tanto mais os seus membros se ressentem da necessidade de se agruparem por afinidades a fim de agirem de comum acôrdo: quanto mais o direito de voto se estende e se multiplica, tanto mais se torna necessário enquadrar os eleitos por comitês capazes de tornar conhecidos os candidatos e de canalizar os sufrágios em sua direção". ${ }^{83}$

Com os partidos políticos e seus programas, “os cidadãos, nesse modelo, não mais escolhem diretamente os governantes; exteriorizam, na realidade, opiniões políticas e a efetiva composição governamental é reservada aos eleitos e aos seus partidos". ${ }^{84}$

Fato é que a representação política passa a ter uma nova perspectiva. Representação e partidos políticos passam a ser elementos inseparáveis. O partido político torna-se instrumento da representação política. E essa situação perdura até os dias atuais. Os partidos tornaram-se parte do processo governamental. ${ }^{85}$

\footnotetext{
${ }^{81}$ DALLARI, Dalmo de Abreu. Elementos de teoria geral do Estado, cit., p. 164.

${ }^{82}$ MANIN, Bernard. As metamorfoses do governo representativo, cit.

${ }^{83}$ DUVERGER, Maurice. Os partidos políticos. Tradução de Cristiano Monteiro Oiticica. Rio de Janeiro: Zahar Editores, 1970. p. 19-20.

${ }^{84}$ DUVERGER, Maurice. Institutions politiques et droit constitutionnel, PUF, Paris, 1971, p. 107 apud CAGGIANO, Monica Herman Salem. Sistemas eleitorais x representação política, cit., p. 17.

${ }^{85}$ Acerca dos partidos políticos, observa Dalmo de Abreu Dallari: "A crítica dos partidos políticos, que envolve a crítica à própria representação política, tem indicado aspectos favoráveis e negativos. A favor dos partidos argumenta-se com a necessidade e as vantagens do agrupamento das opiniões convergentes,
} 


\subsubsection{A Representação Política na Teoria Marxista}

Desde o século XVII discute-se a questão da representação, sobre quem é representado e quais são as relações existentes entre os agentes da representação.

As Constituições modernas, principalmente as européias, registram em seus textos essa preocupação secular. ${ }^{86}$

De fato, as Constituições da França e Espanha, por exemplo, contêm dispositivos que afirmam o princípio da independência parlamentar, no sentido de que o parlamentar representa a nação e não a vontade dos indivíduos. ${ }^{87}$

Por outro lado, as Constituições dos antigos países socialistas também registram a preocupação com a questão da responsabilidade dos representantes, de forma diferente das Constituições ocidentais ${ }^{88}$. Nesse sentido, são as palavras de Sobolewsky: "Desde os tempos da Comuna de Paris o princípio da responsabilidade dos representantes para com seus eleitores, e o direito de removê-los do cargo, tem constituído as bases da teoria socialista da representação, declaradas em todas as Constituições dos países socialistas." 89

Bobbio $^{90}$ lembra que Marx, na sua obra A Guerra Civil na França, deu especial atenção à questão da responsabilidade do representante quando registrou que a Comuna de Paris foi composta por conselheiros municipais eleitos nas diversas

criando-se uma força grupal capaz de superar obstáculos e de conquistar o poder político, fazendo prevalecer no Estado a vontade social preponderante. Além dessa necessidade para tornar possível o acesso ao poder, o agrupamento em partidos facilita a identificação das correntes de opinião e de sua receptividade pelo meio social, servindo para orientar o povo e os próprios governantes. Contra a representação política, argumenta-se que o povo, mesmo quando o nível geral da cultura é razoavelmente elevado, não tem condições para se orientar em função de idéias e não se sensibiliza por debates em torno de questões abstratas. Assim sendo, no momento de votar são os interesses que determinam o comportamento do eleitorado, ficando em plano secundário a identificação do partido com determinadas idéias políticas. A par disso, os partidos são acusados de se ter convertido em meros instrumentos para conquista do poder, uma vez que raramente a atuação de seus membros condiz fielmente com os ideais enunciados no programa partidário. Dessa forma, os partidos, em lugar de orientarem o povo, tiram-lhe a capacidade de seleção, pois os eleitores são obrigados a escolher entre os candidatos apontados pelos partidos, e isto é feito em função do grupo dominante em cada partido. Este aspecto levou ROBERT MICHELS a concluir que há uma tendência oligárquica na democracia, por considerar inevitável essa predominância de grupos (DALLARI, Dalmo de Abreu. Elementos de teoria geral do Estado, cit., p. 167-168).

${ }^{86}$ KINZO, Maria D'alva Gil. op. cit., p. 32.

${ }^{87}$ CAGGIANO, Monica Herman Salem. Direito parlamentar e direito eleitoral, cit., p. 13-14.

${ }^{88}$ KINZO, Maria D'alva Gil. op. cit., p. 32.

${ }^{89}$ SOBOLEWSKY, Marek, Electors and Representatives: A Contribution to the Theory of Representation apud KINZO, Maria D'alva Gil. op. cit., p. 32.

${ }^{90}$ BOBBIO, Norberto. O futuro da democracia. São Paulo: Paz e Terra. 2000. p. 60-61. 
circunscrições da cidade, responsáveis e restituíveis a qualquer tempo ${ }^{91}$, sendo que a idéia de substituição do eleito foi retomada por Lênin na sua obra Estado e Revolução, subsistindo, como mencionado acima, nas várias Constituições soviéticas e socialistas.

A representação política, nesse contexto, referia-se novamente à concepção de mandato imperativo, em contraposição ao mandato nacional e livre.

Segundo Maria D’alva Gil Kinzo ${ }^{92}$, a representação política na teoria marxista relacionava-se ao interesse específico da classe trabalhadora, que possuía uma realidade objetiva independente do fato de ela ter ou não conhecimento de seus interesses, porque os membros dessa classe nascem com o capital. E embora essa classe não tenha a percepção imediata de seus verdadeiros interesses (que é o estabelecimento do Estado socialista), a prática política torna-a possível, enriquecendo sua consciência. Porém, a luta para a realização dos interesses dessa classe necessita de uma direção, que é dada pelo partido. Surge, assim, uma distinção entre a massa proletária, aqueles que não possuem conhecimento de seus interesses, e a vanguarda, provida de capacidade e conhecimento, que representa essa massa, para levá-la adiante à direção e à organização da luta pelo interesse da classe.

Enquanto a classe trabalhadora não tem consciência ainda de seus reais interesses e enquanto o partido conduz a tais interesses, diz a mencionada autora, a representação não é produto das demandas dos representados, pois quem define o que deve ser representado são os representantes. Há, aqui, portanto, uma relação de independência

\footnotetext{
${ }^{91}$ Friedrich Engels, na introdução de A Guerra Civil na França, registrou que a Comuna de Paris havia empregado dois remédios infalíveis: "Em primeiro lugar, preencheu todos os cargos administrativos, judiciais e do magistério através de eleições, mediante sufrágio universal, concedendo aos eleitores o direito de revogar a qualquer momento o mandato concedido. Em segundo lugar, todos os funcionários, graduados ou modestos, eram retribuídos como os demais trabalhadores. O salário mais alto pago pela Comuna era de 6 mil francos. Punha-se desse modo uma barreira eficaz ao arrivismo e à caça aos altos empregos, e isso sem falar nos mandatos imperativos dos delegados aos corpos representativos, que a Comuna igualmente introduziu (ENGELS, Friedrich. Texto de introdução de A Guerra Civil na França. Disponível em: <http://www.ebooksbrasil.org/eLibris/guerracivil.html>. Acesso em: 06 jan. 2009). No Anexo III de A Guerra Civil na França, escreveu Karl Marx: "a Comuna de Paris havia de servir de modelo a todos os grandes centros industriais da França. Uma vez estabelecido em Paris e nos centros secundários o regime comunal, o antigo governo centralizado teria que ceder lugar também nas províncias ao governo dos produtores pelos produtores. No breve esboço de organização nacional que a Comuna não teve tempo de desenvolver, diz-se claramente que a Comuna devia ser a forma política inclusive das menores aldeias do país e que nos distritos rurais o exército permanente devia ser substituído por uma milícia popular, com um tempo de serviço extraordinariamente curto. As comunas rurais de cada distrito administrariam seus assuntos coletivos por meio de uma assembléia de delegados na capital do distrito correspondente e essas assembléias, por sua vez, enviariam deputados à delegação nacional em Paris, entendendo-se que todas os delegados seriam substituídos a qualquer momento e comprometidos com um mandato imperativo (instruções) de seus eleitores" (MARX, Karl. A Guerra Civil na França. Anexo III. eBooksBrasil. Disponível em: <http://www.ebooksbrasil.org/eLibris/guerracivil.html>. Acesso em: 06 jan. 2009).

${ }^{92}$ KINZO, Maria D'alva Gil. op. cit., p. 37-42.
} 
entre representante e representado. No entanto, a partir do momento em que a classe trabalhadora passa a ter consciência de seus interesses, surge uma relação nova entre representante e representado, de correspondência e de dependência, uma vez que a vontade coletiva passa a determinar a ação dos representantes. É nesse contexto que se insere o mandato imperativo na teoria marxista, que se encontra referido não a uma situação presente, mas a um futuro possível. ${ }^{93}$

Todos os países socialistas inseriram em suas Constituições dispositivos prevendo a possibilidade de remoção dos representantes, mas essa situação, na prática, não refletiu a teoria, pois nunca se chegou a um Estado socialista real e o mandato tornou-se propriedade do partido comunista.

\subsubsection{A representação política no Século $X X$}

\subsubsection{O início do século $X X$}

Com as eleições periódicas, partidos de massa, poder legislativo e sufrágio universal, além de inúmeros outros fatores, surgem no século XX novos questionamentos sobre a representação política, questiona-se se novas formas de representação poderiam substituí-la ${ }^{94}$ e, nas primeiras décadas do século, em decorrência do alargamento da

\footnotetext{
${ }^{93}$ KINZO, Maria D’alva Gil. op. cit., p. 40-41.

${ }^{94}$ De acordo com as lições de Dalmo de Abreu Dallari, no século XX, outras concepções de representação aparecem em oposição à representação política, pretendendo substituí-la. Assim, surge a doutrina da representação corporativa e a da representação institucional. A primeira, que tinha como seu maior idealizador Mihail Manoilesco, consistia na ideia de que a representação política e os partidos políticos encontravam-se ultrapassados, sendo necessário buscar uma forma de representação com base nas corporações, que se constituíam em categorias funcionais que exerciam funções sociais específicas, caracterizadas por serem órgãos naturais e de naturezas distintas (econômicas, culturais, sociais etc). Inicialmente, a noção de representação corporativa parecia adequada, pois encontrava suporte em realidades sociológicas. Porém, devido a contradições profundas de seus idealizadores, a doutrina tornou-se imprecisa, perdendo seu sentido, além de ter se associado à concepção de Estado Totalitário, demonstrando, portanto, ser um sistema inferior ao da representação política. Quanto à doutrina da representação institucional, tratou-se, também, de outra tentativa de substituição da representação política, baseada no conceito de instituição de Maurice Hauriou. Tal conceito fundamentava-se na "ideia de empresa que realiza e dura no meio social". A concepção de empresa que tem algo a ser realizado e que terá continuidade pode se referir a qualquer objetivo social, podendo se constituir em uma ordem ou qualquer interesse específico de um grupo social. Assim, podem existir instituições decorrentes da aceitação das teorias políticas que preconizem certa forma de convivência ou certa orientação nas relações de produção. Essas idéias se tornam institucionalizadas a partir do momento em que passam para o plano de realidade e adquirem condições de duração no meio social. Por outro lado, se o objetivo almejado pelo grupo social for a realização de condições que favoreçam a certos interesses, alcançado este e após tornar-se permanente, considera-se instituído o objetivo. A representação de ideias e de interesses estão incluídas no conceito de representação institucional, compreendendo tanto a representação política, como a profissional e a corporativa (DALLARI, Dalmo de Abreu. Elementos de teoria geral do Estado, cit., p. 176-181).
} 
capacidade eleitoral e dos casos bem-sucedidos de democracia semidireta na Suíça e nos Estados Unidos da América do Norte, as consultas populares tornaram-se mais frequentes, e o problema que surgia então era como compatibilizar os mecanismos de democracia semidireta com o sistema representativo. ${ }^{95}$

\subsubsection{A crítica de Hans Kelsen sobre a representação política}

Kelsen fez uma dura crítica à representação política, principalmente à teoria do governo representativo, alegando ser esta uma mera ficção:

A diferenciação das condições sociais conduz a uma divisão de trabalho não apenas na produção econômica, mas também no domínio da criação da lei. A função do governo é transferida dos cidadãos organizados em assembléia popular para órgãos especiais. O princípio democrático de autodeterminação limita-se ao procedimento pelo qual esses órgãos são nomeados. A forma democrática de escolha é a eleição. $O$ órgão autorizado a criar ou executar normas jurídicas é eleito pelos sujeitos cuja conduta é regulamentada por essas normas.

Trata-se de um enfraquecimento considerável do princípio da autodeterminação política. É característico da chamada democracia indireta ou representativa. Essa é uma democracia na qual a função legislativa é exercida por um parlamento eleito pelo povo, e as funções administrativas e judiciária, por funcionários igualmente escolhidos por um eleitorado. Segundo a definição tradicional, um governo é "representativo" porque e na medida em que seus funcionários, durante a sua ocupação do poder, refletem a vontade do eleitorado e são responsáveis para com este. Segundo esta definição, "um governo de funcionários, sejam legislativos, executivos ou judiciários, nomeados ou selecionados por outros processos, que não a eleição popular, ou então que, caso escolhidos por um eleitorado democraticamente instituído, não refletem, na verdade, a vontade da maioria dos eleitores, ou cuja responsabilidade para com os eleitores não pode ser imposta, não é verdadeiramente representativo.

Não pode haver qualquer dúvida de que, julgadas por este teste, nenhuma das democracias ditas "representativas" são de fato representativas. $\mathrm{Na}$ maioria delas, os órgãos administrativo e judiciário são selecionados por outros métodos que não a eleição popular, e, em quase todas as democracias ditas "representativas", os membros eleitos do parlamento e outros funcionários popularmente eleitos, em especial o Chefe de estado, não são responsáveis juridicamente perante o eleitorado.

Para se estabelecer uma verdadeira relação de representação, não basta que o representante seja nomeado ou eleito pelos representados. É necessário que o representante seja juridicamente obrigado a executar a

\footnotetext{
${ }^{95}$ A última década do século XIX e as quatro primeiras décadas do século XX foi a fase de generalização, principalmente na Europa, das instituições de democracia semidireta. Essa fase é considerada a fase das grandes controvérsias em torno, principalmente, da figura do referendo e de sua compatibilização com o sistema representativo (Cf. URBANO, Maria Benedita Malaquias Pires. O referendo: perfil históricoevolutivo do instituto; configuração do referendo em Portugal. Coimbra: Coimbra Ed., 1998.p. 25-27).
} 
vontade dos representados, e que o cumprimento dessa obrigação seja juridicamente garantido. A garantia típica é o poder dos representados de cassar o mandato do representante caso a atividade deste não se conforme aos seus desejos. As Constituições das democracias modernas, porém apenas excepcionalmente conferem ao eleitorado o poder de cassar o mandato de funcionários eleitos. (...)

A fórmula segundo a qual o membro do parlamento não é o representante dos seus eleitores, mas do povo inteiro, ou, como dizem alguns autores, do Estado inteiro, e que, portanto, ele não está obrigado por quaisquer instruções dos seus eleitores e não pode ser por eles destituído, é uma ficção política. (...)

Se os autores políticos insistem em caracterizar o parlamento da democracia moderna, a despeito da sua independência do eleitorado, como um órgão "representativo", se alguns autores chegam mesmo a declarar que o mandat impératif é contrário ao princípio do governo representativo, eles não apresentam uma teoria científica, mas advogam um ideologia política. A função dessa ideologia é dissimular a situação real, é sustentar a ilusão de que o legislador é o povo, apesar do fato de que, na realidade, a função do povo - ou, formulando mais corretamente, do eleitorado - limita-se à criação do órgão legislativo". ${ }^{96}$

Hans Kelsen, retomando a velha questão da relação entre representante e representado, entende que não basta a nomeação ou eleição do indivíduo, sendo necessária a existência de uma obrigação (e aqui trata-se de vínculo jurídico) do representante de executar a vontade dos representados, garantida legalmente pela presença de mecanismo que possibilite "cassar" o mandato conferido ao representante. Se o representante não representa os seus eleitores e não pode ser destituído por estes, então a representação é uma ficção, não existe representação. ${ }^{97}$

\subsubsection{Outras teorias sobre a representação política}

León Duguit no seu Traité de Droit Constitutionnel discorre sobre a teoria da solidariedade social e diz existirem duas espécies de solidariedade: a solidariedade por similitudes e a solidariedade por divisão do trabalho. Quanto à primeira, assevera que representados e representantes possuem necessidades comuns e aspirações idênticas, já que ambos querem a manutenção e o acréscimo das suas forças políticas. Com relação à segunda espécie de solidariedade, afirma Duguit que representados e representantes

\footnotetext{
${ }^{96}$ KELSEN, Hans. Teoria geral do direito e do Estado. Tradução de Luís Carlos Borges. 3. ed. São Paulo: Martins Fontes. 1998. p. 413-414.

${ }^{97} \mathrm{~A}$ questão sobre quem é representado sempre esteve presente nos debates sobre a representação política. Há um sentimento, principalmente por parte dos eleitores, de que eles não são representados. É como se esse sentimento existisse no inconsciente coletivo da sociedade.
} 
vinculam-se em razão da reciprocidade de funções e serviços. Ambos se encontram numa situação jurídica objetiva decorrente do fato da representação, por isso a representação é verdadeiramente uma instituição jurídica. ${ }^{98}$

André Hauriou anotou que efetivamente não há que se falar em representação e sim no estabelecimento de fiscais e censores perante àqueles que exercem o poder político, sendo que este estabelecimento às vezes confere poder decisório. ${ }^{99}$

Maurice Hauriou, por seu turno, desenvolveu a teoria da investidura rejeitando a teoria da delegação, afirmando que esta conduz a resultados lamentáveis porquanto confunde poder de nação com poder de governo, que são absolutamente distintos. Assim, propõe a substituição da idéia de delegação pela de investidura, alegando que a investidura não implica transmissão de poder, como segue: "delegar a alguém é conferir-lhe um poder; investir em alguém é dizer-lhe: vós exercereis o vosso próprio poder, mas o exercereis em meu nome e no meu interesse. Assim a investidura respeita no agente investido o caráter autônomo de seu poder e de sua competência e lhe impõe simplesmente a função de exercer esse poder com uma certa autorização em nome do investidor." 100

Miguel Reale conta que, no século XX, principalmente depois de Kelsen, os juristas optaram por uma solução de técnica jurídica que esvaziou o conceito de qualquer relacionamento ou proporcionalidade entre querer o interesse do povo e decisão do poder soberano. As teorias sociológicas passaram a ocupar espaço. ${ }^{101}$

De fato, como já destacado, hoje, o Direito, por si só, não consegue explicar o fenômeno da representação. Trata-se de um fenômeno multidisciplinar e complexo, que só pode ser compreendido por meio de uma conjugação de aspectos.

As ciências sociais passam a discutir seriamente a representação política, por meio de outras abordagens.

No início dos Anos Sessenta, Warren Miller e Donald Stokes apresentam a teoria da representação política entendida como congruência, no sentido de que deve haver identidade entre eleitores e eleitos, i.e., correspondência entre as posições dos legisladores e dos eleitores. Posteriormente, em 1967, Hanna Pitkin apresenta a idéia de representação

\footnotetext{
${ }^{98}$ DUGUIT, León; Traité de Droit Constitutionnel apud FERREIRA, Luiz Pinto. op. cit., t. 1, p. 185.

${ }^{99}$ HAURIOU, André apud REALE, Miguel. op. cit., p. 45.

${ }^{100}$ HAURIOU, Maurice apud FERREIRA, Luiz Pinto. op. cit., t. 1, p. 180-181.

${ }^{101}$ REALE, Miguel. op. cit., p. 45-46.
} 
como responsividade, segundo a qual governo representativo é o governo responsivo, sensível aos desejos populares. ${ }^{102}$

\subsubsection{A representação política dentro de uma nova perspectiva social e política}

Não obstante ainda sejam alvo de discussão as questões do passado relacionadas à representação política e existam posicionamentos de peso sobre o tema, hoje, os fatos sociais são outros, distintos dos fatos que marcaram os séculos XVII, XVIII, XIX e XX.

O processo eleitoral, a forma de colher o voto do eleitorado, os rápidos resultados das eleições, as pesquisas de opinião de voto, os meios de comunicação, a internet, o marketing, tudo isso, conjugado com a tecnologia, influi no comportamento das pessoas, que passaram a ver o processo político de uma forma diferente, imediatista, baseada em rápidos resultados. O eleitor vê o processo eleitoral com outros olhos. Hoje, a tecnologia está a serviço da política.

Além disso, como observa Bernard Manin ${ }^{103}$, nos últimos anos ocorreu uma clara modificação nas interpretações dos resultados das eleições. Antes dos anos 70, grande parte dos estudos indicava que as preferências políticas baseavam-se nas características sociais, econômicas e culturais dos eleitores. No entanto, novos estudos indicam que os resultados eleitorais tendem a variar de eleição para eleição, mesmo quando inalteradas essas características dos eleitores. Um dos motivos dessa variação dos resultados eleitorais é explicado pela personalização da escolha eleitoral, ou seja, o que tem pesado na escolha do eleitor é a personalidade dos candidatos. Os eleitores tendem, cada vez mais, a votar em uma determinada pessoa e não mais no partido e nos seus programas. O caráter pessoal da relação de representação mais uma vez vem à tona, mas, agora com uma roupagem diferente, aparecendo de modo nítido na relação estabelecida entre Executivo e os eleitores. A escolha do chefe do Executivo é, hoje, a eleição mais importante de todas.

O caráter pessoal da relação de representação passa a ser a regra do jogo. E isso se deve, continua Manin, a duas razões: a) os canais de comunicação política afetam a natureza da relação de representação, e b) as novas condições em que os eleitos exercem o poder. No tocante a esse primeiro aspecto, os candidatos se comunicam diretamente com

\footnotetext{
${ }^{102}$ CAMPILONGO, Celso Fernandes. Op. cit., p. 12-13 e 34-35.

${ }^{103}$ MANIN, Bernard. As metamorfoses do governo representativo, cit.
} 
os eleitores através dos veículos de comunicação, dispensando a mediação dos partidos. A televisão realça intensamente a personalidade do candidato, lembrando a natureza face a face da representação que existiu nos primeiros governos representativos. Os candidatos vitoriosos são os comunicadores, i.e., aqueles que dominam as técnicas de comunicação. Não há um abandono dos princípios do governo representativo, mas uma alteração no tipo de elite selecionada para chegar ao poder. Quanto ao segundo aspecto que leva à personalização da escolha eleitoral, o qual corresponde às novas condições em que os eleitos exercem o poder, Manin observa que os candidatos e os partidos dão preferência à individualidade dos candidatos deixando de lado os programas e plataformas eleitorais. ${ }^{104}$

Diante dessas perspectivas, encontra-se o recall como instrumento para complementar esse jogo, aproximando o representado e o representante, dentro de uma nova dialética política, diante de uma nova realidade social, apesar das dificuldades naturais desse instituto.

Cada concepção de representação política se formou de acordo com a realidade e contexto histórico de determinada época.

$\mathrm{Na}$ Idade Média a representação era civilista porque era a única forma possível de determinadas classes e categorias fazerem-se representar perante o rei.

$\mathrm{Na}$ Inglaterra e na França, com as concepções liberais, criou-se uma forma para a classe burguesa emergente se impor. A representação política tornou-se abstrata, para se combater a nobreza e o clero.

Cresce a participação popular nos séculos XIX e XX. Surgem as massas, os partidos políticos, o nacionalismo, as duas Grandes Guerras e a inquietação sobre quem é representado persiste, não obstante muitos quisessem explicar tal fenômeno.

Não é possível falar em representação política apenas com o pensamento voltado para os séculos que se passaram.

A aproximação entre eleitores e eleitos é um processo inevitável, assim como o aumento do controle e da participação popular. E isso se deve a várias razões, inclusive em virtude da evolução tecnológica.

Além disso, como bem assevera Dalmo de Abreu Dallari, a tendência é que o Estado passe a dar preponderância aos interesses e características de todo o povo, no lugar

\footnotetext{
${ }^{104}$ MANIN, Bernard. As metamorfoses do governo representativo, cit.
} 
de seus interesses próprios ou de interesses de grupos dominantes ou de elites. O povo estará cada vez mais integrado nos fins do Estado. E, conforme afirma o mencionado Professor:

Isso deverá ocorrer em relação a todas as atividades do Estado, tanto no que tange ao atendimento de necessidades fundamentais quanto no que se refere ao bem-estar e ao aprimoramento cultural dos indivíduos. Nesse sentido as predições de Mendès Ferance, de que o domínio do futuro não é somente um problema técnico, implicando uma concepção clara do lugar do homem na cidade e a consideração de objetivos como o pleno emprego, condições de trabalho convenientes e um sistema de vida que favoreça o desenvolvimento cultural e humano. Um dado novo, de fundamental importância, é o crescimento das demandas populares, com a multiplicação dos instrumentos de participação, inclusive associações comunitárias e de grupos sociais diferenciados e conselhos representativos da sociedade, institucionalmente ligados a diferentes setores da Administração Pública. Desse modo a democracia representativa fica mais próxima da democracia direta e o povo fica mais próximo do governo. ${ }^{105}$

Destarte, o estudo do recall torna-se importante, nesse contexto. Nos Estados Unidos o recall funciona como um eficiente mecanismo de controle do poder político e de aproximação entre os eleitores e o eleito, principalmente porque é utilizado em nível municipal, além de o sistema eleitoral ser o majoritário por distritos, o que facilita a aplicação desse instituto. No Brasil e em outros países democráticos, a médio prazo, o recall poderá se tornar também uma eficiente forma de controle político e de aproximação entre eleitores e eleitos, desde que inserido dentro de certas condições. A longo prazo poderá tornar-se mais eficaz ainda, para deixar a política menos imoral e com mais resultados em prol do interesse público. Tudo dependerá do nível de educação da sociedade.

${ }^{105}$ DALLARI, Dalmo de Abreu. O futuro do Estado. 2. ed. rev. e atual. São Paulo: Saraiva, 2007. p. 182-183. 


\section{A ESSÊNCIA DO RECALL}

\subsection{A Definição de Recall}

A tradução do termo inglês recall para o português é a seguinte:

Recall. S.1. Revocação, chamada f. de volta. 2. (milit.) toque m. de chamada. 3. Recordação, lembrança f. 4. Revogação, anulação f. 5. (E.U.A.) Destituição de funcionários públicos, por votação popular. II v. revocar, chamar de volta, mandar voltar 2. Recordar, lembrar. 3. Revogar, anular, cancelar. 4. Destituir, demitir. ${ }^{106}$

Como se vê, o vocábulo é plurívoco. Todavia, os significados que apresentam vínculo direto com esta tese, como substantivo, são "revogação", "destituição" e "anulação", bem como a definição específica de recall, no sentido de "destituição de funcionários públicos, por votação popular” e, como verbo, os significados "revogar", "anular", "cancelar" e "destituir".

O Black's Law Dictionary ${ }^{107}$ traz a seguinte definição de recall na língua inglesa:

n.1. Removal of a public official from office by popular vote. 2. A manufacturer's request to consumers for the return of defective products for repair or replacement. 3. Revocation of a judgement for factual or legal reasons. ${ }^{108}$

O termo recall designa, portanto, pelo aspecto jurídico, tanto o instituto que é objeto de estudo nesta tese como o procedimento relacionado às relações de consumo, no qual o fabricante convoca os consumidores, por meio de ampla divulgação na imprensa, para apresentarem um produto supostamente defeituoso para reparação de defeitos ou mesmo para sua substituição, visando proteger a integridade física do consumidor e diminuir o risco de quaisquer espécies de danos.

\footnotetext{
${ }^{106}$ MICHAELIS. Dicionário ilustrado: inglês-português. Impresso em Portugal: Melhoramentos, 2000. v. 1, p. 789.

${ }^{107}$ BLACK'S Law Dictionary. Seventh Edition. Bryan A. Garner Editor. St. Paul, Minnesotta: West Group, 1999. p. 1274.

${ }^{108}$ Em português: n. 1. Exoneração de funcionário público de suas funções mediante votação popular. 2. Solicitação do fabricante aos consumidores para a devolução de produtos defeituosos para reparo ou substituição. 3. Anulação (ou revogação) de julgamento por razões factuais ou legais.
} 
Assim, estabelecidos todos os significados da palavra recall, o foco volta-se para o cerne deste estudo, que é o procedimento que trata especificamente da destituição de agentes públicos e da revogação de ordens judiciais, mediante decisão popular.

Frederick L. Bird conceitua recall como "técnica política destinada a permitir ao eleitorado, mediante uma eleição especial, a substituição de um funcionário público antes da extinção normal do tempo de exercício das suas funções". ${ }^{109}$

Thomas E. Cronin ${ }^{110}$ conceitua recall como o dispositivo de democracia formal que confere aos eleitores a possibilidade de destituir e substituir uma autoridade pública. $\mathrm{E}$ sobre a concepção do instituto, registra o mesmo autor que a idéia de recall baseia-se na noção de que os eleitores devem conservar o direito de controlar suas autoridades eleitas. Os candidatos podem ter sido eleitos por um grande número de razões, incluindo algumas que não têm qualquer relação com sua capacidade para exercer seus deveres públicos de forma competente. A premissa do recall é que se as pessoas podem ser eleitas por motivos não-relacionados à sua capacidade para exercer a função pública, eles também podem ser destituídos por uma série de motivos. ${ }^{111}$

Segundo William Bennett Munro ${ }^{112}$, o recall pode ser definido como o direito de um determinado número de eleitores de requerer a imediata remoção de um governante ou qualquer outro ocupante de cargo eletivo, bem como de ter seu requerimento submetido aos eleitores para decisão. Diz também o mesmo autor que o recall baseia-se na ideia de que o povo deve manter o maior controle possível sobre as suas autoridades eleitas ou, como diz um velho ditado de Oregon, o povo deve ser capaz de destituir seus agentes públicos "da mesma forma que um fazendeiro pode demitir seu empregado". ${ }^{113}$

Manoel Gonçalves Ferreira Filho rotula o instituto como direito de arrependimento. $^{114}$

Segundo Meirelles Teixeira, recall ou revogação é o "direito, atribuído ao povo, de suprimir os efeitos (revogar) dos mandatos de seus representantes, isto é, certos

\footnotetext{
${ }^{109}$ BIRD, F.L. "recall”, no ESS, XIII, p. 147 apud FERREIRA, Luiz Pinto. op. cit., t. 1, p. 155-156.

${ }^{110}$ CRONIN, Thomas E. op. cit., p. 125.

${ }^{111}$ Id. Ibid., p. 130.

${ }^{112}$ MUNRO, William Bennett. The government of the United States: national, state and local. 5. ed. New York: The MacMillan Company, 1949. p. 672.

${ }^{113}$ Id. Ibid., p. 298.

${ }^{114}$ FERREIRA FILHO, Manoel Gonçalves Apud CAGGIANO, Monica Herman Salem. Oposição na política: propostas para uma rearquitetura da democracia. São Paulo: Angelotti, 1995. p. 97.
} 
atos legislativos julgados inconvenientes para o interesse coletivo, ou mesmo de revogar o próprio mandato". 115

Para Monica Herman Salem Caggiano, o recall é um instituto de direito público típico dos Estados Unidos que "confere ao eleitorado a faculdade de, antes da extinção normal do mandato conferido a um cidadão e por intermédio de nova manifestação do povo, destituí-lo, indicando-lhe o sucessor ".116

Sobre o instituto em questão, Darcy Azambuja ensina que "Em alguns estados da União Americana tem tido larga aplicação, não somente para membros da Câmara como para membros do Executivo e do Judiciário, o recall. Um certo número de eleitores, de 20 a $25 \%$ do total pode pedir que o cidadão seja submetido ao recall, ou revogação. $\mathrm{O}$ indivíduo submetido ao procedimento de recall pode apresentar-se à reeleição e imprimir na cédula de voto sua defesa. Se for reeleito, correm por conta dos peticionários do recall as despesas feitas com a eleição, para o que previamente eles são obrigados a prestar caução". 117

Para Themistocles Cavalcante ${ }^{118}$ o recall é um processo de responsabilidade do direito americano que procura corrigir as faltas do sistema representativo.

Sobre o instituto em questão, Osvaldo Trigueiro ${ }^{119}$ afirma que, por meio do recall, "o eleitorado pode revogar os mandatos políticos, antes de sua expiração. Catalogado impropriamente, por alguns escritores, entre os processos de legislação direta, o recall é antes uma forma sumária de impeachment popular".

Aderson de Menezes ${ }^{120}$, por sua vez, relata que Barthélemy, Duez, Biscaretti Di Ruffia e Esmein entendem que o recall se trata de uma aplicação aos afazeres políticos do conhecido good business principle, segundo o qual o empregador pode dispensar a qualquer tempo, o empregado que se mostra incapaz ou desonesto.

Maria Benedita Malaquias Pires Urbano ${ }^{121}$ diz que:

\footnotetext{
${ }^{115}$ TEIXEIRA, J. H. Meirelles. op. cit., p. 478.

${ }^{116}$ CAGGIANO, Monica Herman Salem. Sistemas eleitorais x representação política, cit., p. 30.

${ }^{117}$ AZAMBUJA, Darcy. op. cit., p. 236.

${ }^{118}$ CAVALCANTI, Themistocles Brandão. Teoria do Estado. Rio de Janeiro: Borsoi, 1958. p. 328.

${ }^{119}$ TRIGUEIRO, Osvaldo. O regime dos Estados na união americana. Rio de Janeiro: Companhia Ed. Americana, 1942. p. 140.

${ }^{120}$ MENEZES, Aderson de. Teoria geral do Estado. 8. ed. rev. e atual. por José Lindoso. Rio de Janeiro: Forense, 1998. p. 361.

${ }^{121}$ URBANO, Maria Benedita Malaquias Pires. op. cit., p. 79-80.
} 
O direito de revocação popular consiste num meio ou procedimento ao dispor de um certo número ou percentagem de cidadãos eleitores, o qual tem como finalidade permitir-lhes requerer a destituição de um ou mais dos seus representantes, hajam eles sido eleitos ou nomeados (a lógica dessa figura compagina-se bem melhor, porém, com a ideia de eleição: se o povo tem o poder de eleger os seus representantes, deverá também deter o poder de os destituir quando estes frustrem as expectativas nele depositadas, antes de expirar o prazo relativo ao cargo que estão a exercer. A eventual revocação terá lugar por via de uma eleição em que o povo é questionado sobre se pretende manter ou não em funções o representante visado. Em poucas palavras, trata-se de uma substituição antecipada de representantes.

Por fim, Dalmo de Abreu Dallari ${ }^{122}$ leciona que o recall é uma instituição norte-americana aplicada para revogar a eleição de um legislador ou funcionário eletivo, ou para reformar decisão judicial que trata de constitucionalidade de lei, sendo que, no primeiro caso, é necessário que determinado número de eleitores requeira uma consulta ao eleitorado sobre a manutenção ou revogação do mandato conferido a alguém, exigindo-se dos requerentes uma caução em dinheiro. Caso a maioria decida pela revogação, o indivíduo perde o cargo e, na hipótese contrária, o mandato não se revoga e o Estado fica definitivamente com o dinheiro depositado. ${ }^{123}$

Ao cabo das opiniões de peso que tivemos a oportunidade de apresentar, percebe-se que o recall é entendido como mecanismo de controle político, diretamente relacionado à responsabilidade do representante e também como forma de correção dos problemas da representação política. Além disso, trata-se também de um procedimento eleitoral, dividido geralmente em duas fases distintas. A primeira se assemelha muito ao procedimento de iniciativa legislativa popular, uma vez que, para dar início ao mecanismo de recall, é necessário que uma parcela do eleitorado confirme sua intenção de instaurar o procedimento e de levar a questão da manutenção ou não do agente público à votação popular. Na segunda fase os eleitores decidem, por meio de votação, sobre a destituição e substituição do agente público. Não somente isso, o recall envolve também uma questão de responsabilidade de quem promove a instauração do procedimento, uma vez que, em muitos casos, no direito norte-americano, exige-se uma caução em dinheiro como requisito

\footnotetext{
${ }^{122}$ DALLARI, Dalmo de Abreu. Elementos de teoria geral do Estado, cit., p. 155.

${ }^{123}$ André Hauriou registra que, para evitar o abuso ou má-utilização do recall, foram adotados nos Estados Unidos, além do fato de os peticionários assumirem o encargo financeiro do recall na hipótese de nãorevogação do mandato ou da ordem judicial, outros procedimentos, tais como a impossibilidade de o mecanismo ser provocado antes de seis meses contados da posse do agente público e a possibilidade de ser utilizado apenas uma única vez contra o mesmo indivíduo, durante a vigência do seu mandato (HAURIOU, André.op. cit., p. 64-65).
} 
prévio para o funcionamento do mecanismo, com o objetivo de diminuir o risco de aventuras políticas e de promover uma reparação pela movimentação do aparato eleitoral sem justificativa.

Por fim, o recall relaciona-se com a idéia de "good business principle", no sentido de que a Administração Pública, governo, representantes e governantes devem ser honestos e competentes, devendo ser destituídos como se fossem empregados do povo, na hipótese de não seguirem esses princípios.

Em que pese essas indicações iniciais servirem para a formação de um conceito próprio desse instituto, apenas no final desta tese, com as conclusões finais, é que será apresentada uma definição própria do mencionado instituto.

\subsection{As origens do Recall}

\subsubsection{A perda de função pública por decisão popular no passado remoto}

Casos de perda de função de natureza pública por meio de votação, conforme já registrado no início desta tese, já existiam na Grécia Antiga, quando os magistrados que exerciam funções públicas podiam ser destituídos da função por meio dos votos daqueles que o haviam elegido.

$\mathrm{Na}$ democracia ateniense existia também o instituto do ostracismo, que permitia o banimento de uma autoridade por meio dos votos dos cidadãos, que resultava no exílio do indivíduo por um período de dez anos. ${ }^{124}$

Durante o Período Medieval e mesmo durante a Idade Moderna havia o mandato imperativo, quando se permitia a revogação do mandato de um representante por seus representados, dentro de uma relação típica civilista.

Na Suíça havia um mecanismo para isolar as autoridades de cada uma das unidades da Confederação antes do término dos seus mandatos, que permitia a um número determinado de cidadãos requerer uma votação especial para destituir um parlamentar ou

\footnotetext{
${ }^{124}$ CRONIN, Thomas E. op. cit., p. 128.
} 
membro de conselho. Tal dispositivo passou a integrar a legislação suíça a partir de 1850 , embora já fizesse parte dos costumes do povo muito antes dessa data. ${ }^{125}$

\subsubsection{Estados Unidos}

\subsubsection{Período colonial}

A palavra recall nos faz lembrar automaticamente os Estados Unidos da América do Norte. Quando se discute o instituto nos meios de comunicação ou quando há alguma referência escrita ou falada sobre o tema, o primeiro exemplo que é lembrado, de forma até inconsciente, é o recall dos norte-americanos.

Conforme será verificado, apesar de ter sofrido várias influências, o recall é um instituto norte-americano que possui características próprias.

Segundo Joshua Spivak ${ }^{126}$, a primeira previsão normativa sobre um mecanismo de revogação de mandato pelos eleitores nos Estados Unidos surgiu nas leis denominadas General Court of Massachussetts Bay Colony, no ano de 1631, aparecendo, posteriormente, também, na "Colony Charter" de 1691.

No século XVII, o direito nas colônias era pouco desenvolvido, não havia ainda a influência do common law nessas localidades e as leis escritas fundamentavam-se na Bíblia ${ }^{127}$. Grande parte das populações dessas colônias era formada por puritanos ingleses que haviam sofrido perseguição religiosa em seu país de origem e possuíam a ideia de que o governo e as leis deveriam seguir a vontade da maioria. Os puritanos exerciam um forte controle na vida das pessoas para manter a união das comunidades. Pelo aspecto político, esse fato resultou numa rígida fiscalização dos atos daqueles que agiam em nome do grupo social. ${ }^{128}$

\footnotetext{
${ }^{125}$ CRONIN, Thomas E. op. cit., p. 129.

${ }^{126}$ SPIVAK, Joshua. California's recall: adoption of the grand bounce for elected officials. California History, v. 81, n. 2, p. 22, 2004.

${ }^{127}$ DAVID, René. Os grandes sistemas do direito contemporâneo. São Paulo: Martins Fontes, 2002. p. 450.

${ }^{128}$ Leandro Karnal registra que "para manter sua identidade, seu sentimento de grupo, os puritanos exerceram um controle muito grande sobre todas as atividades dos indivíduos. Esse controle foi realmente forte, a ponto de hoje ainda empregarmos o adjetivo puritano para todas as pessoas que vivem controlando-se e controlando os outros, em especial no universo sexual. Esse controle nascia exatamente da necessidade de manter a unidade e a coesão do grupo" (KARNAL, Leandro. Estados Unidos: a formação da nação. São Paulo, Contexto, 2007, p. 39).
} 
A colonização dos Estados Unidos partiu da iniciativa privada, sem a presença do Estado. A coroa (no caso, a Dinastia Tudor) delegou aos particulares a incumbência de promover a colonização no Novo Mundo. Posteriormente, com a Dinastia Stuart surgem as Companhias de Londres e a de Plymouth que receberam as terras para exploração do comércio. $^{129}$

Todo esse conjunto de fatores criou o sentimento de independência que engendrou a raiz da autonomia político-administrativa das colônias.

Alexis de Tocqueville ${ }^{130}$ registrou que, no período colonial, não obstante a existência na época de certos exageros de índole religiosa, os princípios gerais que fundamentaram as Constituições modernas eram todos reconhecidos e instituídos, de fato e sem discussão, pelas leis da Nova Inglaterra. Essas leis, antes das revoluções européias dos séculos XVII e XVIII, já previam, por exemplo, a intervenção do povo nas coisas públicas, as responsabilidades dos agentes do poder, a liberdade individual e o julgamento pelo júri.

A forma primitiva do recall apareceu, portanto, no período colonial, dentro desse contexto, de forma não-uniforme, permitindo ocasionalmente a revogação do mandato dos representantes, possivelmente inspirada nas participações políticas das sociedades antigas e no mandato imperativo medieval. As instruções, como já ressaltado, sempre estiveram presentes no período colonial.

A participação dos indivíduos nas decisões de governo em nível local é uma tradição norte-americana. No período colonial existiam as Assembléias eleitas pela população que decidiam sobre orçamento e leis. Em Massachussets (ou seja, no mesmo local onde se revogavam mandatos de representantes nos meados do século XVII) havia as Town Meetings que consistiam em reuniões dos cidadãos em local público para decidirem sobre todos os assuntos de interesse da comunidade.

Houve, portanto, uma forte tradição de participação política na formação do povo norte-americano, inclusive permitindo a revogação de mandatos.

\footnotetext{
${ }^{129}$ KARNAL, Leandro. op. cit., p. 32-33.

${ }^{130}$ TOCQUEVILLE, Alexis de. A democracia na América. Tradução Eduardo Brandão. 2. ed. São Paulo: Martins Fontes, 2005. Livro1. Leis e costumes, p. 47.
} 


\subsubsection{A revogação de mandatos nos Artigos da Confederação e nas Convenções de Ratificação}

Há registros de que na época dos Artigos da Confederação (1781-89) foram apresentadas propostas para criação de um instituto muito semelhante ao recall. ${ }^{131}$

Segundo Thomas E. Cronin, a idéia de revogação de mandatos foi também discutida nas convenções de ratificação de 1787 e 1788. Na convenção de Nova Iorque, v.g., foi apresentada uma proposta de emenda constitucional para permitir às legislaturas estaduais destituírem um ou os dois senadores do cargo, elegendo outros para substituí-los no cargo pelo período restante do mandato. ${ }^{132}$

Ocorreram inflamados debates sobre o tema, principalmente no que se referia à adoção de mecanismo para remoção de senadores. No entanto, a ideia foi deixada de lado, em grande parte, pela influência de Alexander Hamilton que considerava o procedimento uma ameaça aos ocupantes de cargo eletivo, por entender que, com a adoção deste instrumento, os governantes poderiam se tornar escravos dos humores e caprichos dos indivíduos. ${ }^{133}$

$\mathrm{Na}$ verdade, o que ocorreu foi que a ideia de inserir um dispositivo sobre revogação de mandatos na Constituição se esvaneceu por falta de apoio, principalmente daqueles que participavam das convenções de ratificação. ${ }^{134}$

\subsubsection{A destituição das autoridades públicas e a revogação das ordens judiciais por decisão popular. $O$ instrumento progressista denominado recall}

A revogação de mandatos pelos eleitores ressurge com força nos Estados Unidos no final do século XIX e início do Século XX, principalmente no Estado da Califórnia, agora denominada recall, para combater, no caso específico desse Estado norte-americano, os abusos econômicos praticados pela Southern Pacific Railroad, bem como por força das ideias políticas que haviam se afirmado no país na virada do século XIX. $^{135}$

\footnotetext{
${ }^{131}$ CRONIN, Thomas E. op. cit., p. 129.

${ }^{132}$ Id. Ibid., p. 129.

${ }^{133}$ SPIVAK, Joshua. op. cit., p. 22.

${ }^{134}$ CRONIN, Thomas E. op. cit., p. 129.

${ }^{135}$ A Southern Pacific Railroad era uma empresa privada ferroviária que realizava o transporte, tanto de mercadorias como de passageiros, pela Costa do Pacífico. (Cf. SPIVAK, Joshua. op. cit.,p. 23-24).
} 
Havia, à época, nos Estados Unidos e em especial na Califórnia, uma facção do Partido Republicano, denominada Progressive Movement, que pretendia acabar com a influência dos grandes grupos econômicos (principalmente com a influência da mencionada empresa ferroviária) sobre políticos e juízes.

Arthur A. Ekirch Jr. ${ }^{136}$, historiador americano e ex-professor da Universidade Estadual de Nova Iorque, teceu ricas observações acerca do movimento progressista americano.

Segundo esse autor, o movimento progressista foi inspirado nos movimentos europeus para o socialismo estatal. No final do século XIX, uma considerável parte dos estudantes americanos se diplomava na Europa, onde tinham contato com os programas de reforma social da Inglaterra e de outros países europeus. Ao voltarem para os Estados Unidos, muitos desses novos profissionais acabaram exercendo funções públicas. Foi surgindo, assim, nos Estados Unidos, um movimento com idéias de reforma da sociedade e de interpretação nacionalista da democracia, para conter e corrigir os abusos econômicos e a corrupção. $^{137}$

Theodore Roosevelt abraçou fortemente essa tendência e tornou-se o maior líder popular do movimento progressista, ganhando fama como perseguidor de monopólios e trustes econômicos, muito embora, na verdade, não tenha sido tão radical assim com tais corporações.

Ainda conforme as lições de Arthur A. Ekirch Jr. ${ }^{138}$, as ideias e reformas progressistas, principalmente as de natureza democrática, começaram a ter aplicação local devido à expansão das cidades que passaram a exigir dispendiosos serviços municipais. $\mathrm{O}$ crescimento das cidades produziu vultosos contratos de obras, gerando privilégios, fraudes e corrupção em nível local. Os defeitos dos governos estaduais e das cidades resultaram em necessidades de reforma e as cidades americanas passam a ser a esperança da democracia, sob o argumento de que a democracia funcionava melhor nos governos municipais, onde o

\footnotetext{
${ }^{136}$ EKIRCH JR., Arthur A. A democracia americana: teoria e prática. Tradução de Álvaro Cabral e Constantino Paleólogo. Rio de Janeiro: Zahar, 1965. p. 179-202.

${ }^{137}$ No final do século XIX e começo do século XX, sob influência desses novos fatores, houve na literatura americana um aumento do espírito crítico, com sátiras sobre a corrupção política e críticas aos homens de negócios. Surge a chamada literatura Muckraking da era progressista, com crescente aumento de tiragem de exemplares de jornais e revistas, o que demonstrava um crescente aumento do interesse público sobre tais temas (EKIRCH JR., Arthur A. op. cit., p. 186-187).

${ }^{138}$ EKIRCH JR., Arthur A. op. cit., p. 179-202.
} 
povo estava mais familiarizado com as questões locais e onde a opinião pública era mais presente.

Thomas E. Cronin ${ }^{139}$ assevera que, além dos progressistas, em 1890, os Partidos Populista e Socialista já incitavam a adoção do recall em nível nacional e estadual, sob o argumento de que os governos estavam infestados de pessoas corruptas e privilegiadas. Para eles o dinheiro e o lobby subvertiam a democracia representativa e aí passaram a afirmar que o representante seria um agente e não o patrão. O representante que deixasse de atender à vontade dos representados ou que se afastasse das necessidades e aspirações do povo deveria ser destituído do cargo. Ademais, tanto os populistas como os progressistas entendiam que os dispositivos legais existentes sobre o impeachment eram inadequados e pouco úteis, pois esse instituto punia apenas a prevaricação, deixando sem penalidade o abuso de autoridade e a omissão, sem contar que o suborno era de difícil comprovação. Tais partidos entendiam que aqueles que pretendiam destituir uma autoridade do cargo por meio do procedimento de impeachment deveriam provar previamente a prática de um crime, por isso tal mecanismo seria praticamente inútil e inadequado diante das dificuldades existentes para promoção prévia dessa prova. E, por outro lado, as acusações para o recall eram mais fáceis de serem produzidas, pois podiam tratar desde a presunção de falta de representatividade da autoridade, como de outros fatos como, por exemplo, indiferença quanto às responsabilidades inerentes ao cargo e promoção de gastos inúteis. De modo diverso ao impeachment, o recall seria proveniente da ação política de grupos de cidadãos e não de deliberações legislativas.

As principais inovações democráticas da era progressista consistiam na iniciativa popular, no referendo e na destituição dos funcionários públicos por meio de votação, que foi denominada recall. Como dito, a ideia de governo direto parecia ser mais apropriada aos governos locais do que aos estaduais. A democracia direta foi a forma encontrada para manter o governo ligado ao povo, como forma de controle popular da política. A ideia era a de que o melhor governo baseava-se em mais e não em menos democracia. ${ }^{140}$

Destarte, foi o movimento progressista americano (apoiado por partidos de esquerda) que resgatou o primitivo recall das antigas colônias, agora, com novas inspirações trazidas do Velho Continente. O recall da era progressista veio, portanto, com

\footnotetext{
${ }^{139}$ CRONIN, Thomas E. op. cit., p. 130.

${ }^{140}$ EKIRCH JR., Arthur A. op. cit., p. 193-194.
} 
uma nova roupagem, inspirado nos acontecimentos históricos europeus do século XIX. A democracia semidireta com foco nos governos locais era o que havia de mais moderno em termos de política.

De forma diversa, André Hauriou ${ }^{141}$ vê a origem do recall com foco apenas na Suíça, desconsiderando que nos Estados Unidos já havia, no século XVII, práticas de revogação de mandatos pelos colonos e, no século XVIII, tentativas para permitir novamente sua utilização, sem levar em consideração também o fato de que muitos estudantes americanos tiveram contato na Europa, no final do século XIX, com a obra intelectual de Karl Marx, que abordava o assunto da revogação popular dos mandatos.

Embora seja relevante investigar quais foram os motivos que inspiraram o recall introduzido no início do século $\mathrm{XX}$ nos Estados Unidos ${ }^{142}$, fato é que os mecanismos de participação popular, a exemplo do referendo, plebiscito e recall foram as armas encontradas pelos progressistas para combater o poder dos grandes grupos econômicos que atuavam regionalmente nos estados-membros e nas grandes cidades americanas.

Cronin $^{143}$ observa que, até 1900 , poucas e pequenas localidades haviam implementado o recall em suas legislações. Los Angeles, controlada por políticos vinculados aos interesses de grupos econômicos, principalmente à empresa ferroviária Southern Pacific Railroad, foi o primeiro Estado importante a inserir o recall em suas leis orgânicas municipais.

Segundo Spivak ${ }^{144}$, por influência do líder progressista John Haynes, em 1903, a cidade de Los Angeles editou uma lei instituindo o recall, que foi utilizada para remover ocupantes de cargos públicos na Prefeitura por prática de atos ilícitos.

Durante a primeira década do Século XX, os progressistas da Califórnia continuaram a desafiar os poderes da Southern Pacific Railroad, pois conseguiram, na

\footnotetext{
${ }^{141}$ Para André Hauriou, a pátria de origem do recall norte-americano é a Suíça, onde se instaurou nos meados do século XIX o instituto denominado abberufungsreicht, que tratava da revogação de todos os mandatos da assembleia legislativa. Para o jurista francês, este instituto foi a verdadeira inspiração do recall. Para ele, houve uma espécie de importação deste mecanismo suíço para utilização em terras americanas, onde encontrou um ambiente extremamente favorável, expandindo-se rapidamente com o nome de recall, adaptando-se de tal forma a ponto de ser aplicado a todos os funcionários que integravam o governo (HAURIOU, André. op. cit., p. 64).

${ }^{142} \mathrm{Na}$ verdade, foi um conjunto de fatos e de influências. Todos foram relevantes e influenciaram a instituição do recall no país, desde o histórico de participação popular do povo norte-americano e de casos no passado de revogação de mandatos populares nesse país, até os ideais socialistas e os exemplos suíços.

${ }^{143}$ CRONIN, Thomas E. op. cit., p. 130.

${ }^{144}$ SPIVAK, Joshua. op. cit., p. 23.
} 
cidade de São Francisco, promover condenações de funcionários públicos e juízes por prática de corrupção.

Com a eleição de Harim Johnson (um dos promotores de justiça desses casos de corrupção de São Francisco) para governador da Califórnia, em 1910, os progressistas ganharam fôlego e apresentaram projetos de emendas constitucionais estaduais para instituir o referendo, a iniciativa legislativa popular e o recall. Houve um grande debate sobre a possibilidade de se revogar o mandato de juízes, principalmente em razão do princípio da independência do Poder Judiciário. ${ }^{145}$ Paralelamente, foram ressuscitados os julgamentos de corrupção de São Francisco, o que gerou um enorme alvoroço político que estimulou os deputados estaduais a apoiarem o recall em sua totalidade, inclusive com a possibilidade de remoção de juízes. ${ }^{146}$

Em 1911, na Califórnia, foram definitivamente aprovados o referendo, a iniciativa legislativa popular e o recall.

O recall foi instituído também no estado de Oregon, antes da Califórnia, em junho de 1908 e, ao longo do século XX, muitos outros Estados e cidades passaram a contar com tal mecanismo em suas Constituições e leis orgânicas. ${ }^{147}$

\subsubsection{Países Socialistas}

Em sentido oposto, como já registrado, surge a figura da revogação do mandato, antes da instituição do recall nos Estados Unidos, na Comuna de Paris de 1871. Sobre o tema, as palavras de Norberto Bobbio ${ }^{148}$ são elucidativas:

Se depois de considerarmos o mandato livre como um instituto característico da democracia representativa, haveremos de convir que sua crítica mais radical veio do movimento operário de inspiração marxista, a reboque das famosas reivindicações de uma representação verdadeira e própria, e portanto com poder de revogação do mandato por parte do

\footnotetext{
${ }^{145}$ Fundamentalmente, o que se alegava à época, com relação à objeção do recall dos juízes, é que, diferentemente do Executivo e do Legislativo e não obstante o processo de escolha dos magistrados fosse por meio de eleição, os juízes executam suas funções pelo governo considerado como um todo, não no interesse de uma maioria, não sendo o Judiciário um órgão representativo, mas um órgão conservador permanente, no qual seus servidores, para exercerem o cargo de forma adequada, devem ser Independentes. (Cf., WILCOX, Delos F. Government by all the people or the initiative, the referendum and the recall as instrumet of democracy. New York: The MacMillan Company, 1912. p. 211-212; BEARD, Charles E; SHULTZ Bill E. Documents on state-wide: initiative, referendum and recall. New York: The Macmillan Company, 1912. p. 249-251).

${ }^{146}$ SPIVAK, Joshua. op. cit.,p. 25-28.

${ }^{147}$ CRONIN, Thomas E. op. cit., p. 131.

${ }^{148}$ BOBBIO, Norberto. Teoria geral da política: a filosofia política e a lição dos clássicos, cit., p. 467.
} 
mandante, feita pelo próprio Marx no comentário aos acontecimentos da Comuna de Paris. A revogação do mandato foi introduzida nas sucessivas constituições soviéticas, depois de ter sido proclamada no momento da derrubada do antigo poder como único instituto que a democracia representativa operária poderia permitir, aproximando-a da democracia direta. Assim, o movimento operário revolucionário fazia retornar com honra um instituto que a democracia "burguesa" havia suprimido, tendo-o reputado anacrônico.

Em 1917, o mandato imperativo reaparece na obra de Vladimir Lênin, Estado e Revolução. ${ }^{149}$

Por influência de Lênin, o art. 105 da Constituição da União das Repúblicas Socialistas Soviéticas de 1917 permitiu a revogação do mandato dos deputados, conforme se verifica, in verbis:

O deputado tem o dever de informar os eleitores sobre a sua atividade e sobre a atividade dos soviets. $\mathrm{O}$ deputado que não se mostrar digno de confiança dos eleitores pode ser privado do mandato a qualquer momento por decisão da maioria dos eleitores e segundo as modalidades previstas por lei.

A revogação do mandato político na União Soviética, de forma diversa da norte-americana, não se fundamentou nos costumes e nos ideais democráticos, nem tampouco nas idéias de governo local e do "good business principle" e sim em objetivos políticos diretamente vinculados ao regime que por lá se implementou, em reação ao mandato representativo burguês.

Como observou Paulo Bonavides, na antiga União Soviética institui-se uma espécie de mandato imperativo dos chamados representantes das classes trabalhadoras e os

\footnotetext{
${ }^{149}$ Lênin não inova, apenas cita em sua obra as observações anteriormente feitas por Engels na introdução de A Guerra Civil na França, in verbis: "Engels acentua, mais uma vez, que, não só numa monarquia como também numa República democrática, o Estado continua a ser Estado, isto é, conserva o seu caráter distintivo fundamental, que é o de transformar os empregados, órgãos e 'servidores da sociedade', em senhores da sociedade. Para evitar essa transformação - até então inevitável em todos os regimes - do Estado, de servidor em senhor da sociedade, a Comuna empregou dois métodos infalíveis. Primeiro, ela submeteu todos os cargos, na administração, a justiça e o ensino, à escolha dos interessados, por eleição, por sufrágio universal. Depois, retribuiu esses serviços, superiores como inferiores, com um salário igual ao que recebem os outros trabalhadores. O maior vencimento foi fixado em 6.000 francos (9). Dessa forma, foi posto um freio à caça ao emprego, ao arrivismo, sem contar que o mandato imperativo que era imposto, além do mais, aos delegados às assembléias legislativas. (LÊNIN, Vladimir. Estado e a revolução. Prefácio de Florestan Fernandes. Cultura Brasil). Disponível em: <http://www.culturabrasil.org/zip/oestadoearevolucao.pdf.Página 84>. Acesso em: 12 jan. 2009.
} 
deputados estavam obrigados a prestar contas aos eleitores sobre os trabalhos realizados, podendo ser destituídos a qualquer tempo. ${ }^{150}$

O recall foi mantido pela Constituição Soviética de 1936 e outros países socialistas também o adotaram, a exemplo da Hungria, Romênia, Bulgária e Polônia.

\subsubsection{O Abberufungsrecht da Suíça}

Na Suíça há o tradicional instituto denominado Abberufungsrecht que prevê a revogação coletiva de todos os mandatos políticos da assembleia. Obviamente, não se trata aqui de recall, pois o procedimento abrange a revogação geral de todos os mandatos políticos de uma só vez.

O termo em alemão significa literalmente "direito de chamada", mas seu significado político-jurídico é "direito de dissolução popular". ${ }^{151}$

Biscaretti Di Ruffia ${ }^{152}$ conceitua o instituto suíço como sendo o "poder conferido a uma determinada fração do corpo eleitoral (geralmente igual àquela exigida para um pedido de referendum) de submeter aos votos dos eleitores a proposta de dissolver a assembléia representativa e enunciar imediatamente novas eleições; se a proposta for acolhida por maioria do corpo eleitoral a assembléia se dissolve com efeito imediato".

Citando Marcel Prelót, sobre o referido instituto suíço, registra Paulo Bonavides que "requerida a dissolução, por determinada parcela do corpo eleitoral, a assembléia só terá findo seu mandato após a votação da qual resulte patente pela participação de apreciável percentagem constitucional de eleitores que o corpo legislativo decaiu realmente da confiança popular". ${ }^{153}$

André Hauriou ${ }^{154}$ ensina que, em 1852, os cantões de d'Argovie e Schaffouse organizaram, o que se chama nos países de língua germânica, Abberufungsrecht, que é o direito de dissolução popular da assembleia quando um número determinado de cidadãos pede a renovação da assembleia legislativa, submetendo tal questão diretamente à votação

\footnotetext{
${ }^{150}$ BONAVIDES, Paulo. op. cit., p. 292.

${ }^{151}$ MENEZES, Aderson de. op. cit., p. 359.

${ }^{152}$ RUFFIA, Biscaretti Di. Lo Stato Democratico Moderno, vol. I, p. 410 apud MENEZES, Aderson de. op. cit., p. 359.

${ }^{153}$ PRELÓT, Marcel apud BONAVIDES, Paulo. op. cit., p. 294.

${ }^{154}$ HAURIOU, André.op. cit., p. 63.
} 
popular. Se a maioria se pronuncia no sentido de renovar a câmara legislativa, os poderes desta cessam imediatamente e procede-se, na seqüência, às eleições gerais.

O Abberufungsrecht é mais um instituto sui generis do sistema suíço, que trata da revogação de todos os mandatos de uma assembléia.

Após a Primeira Guerra Mundial, a Prússia e a Saxônia acolheram o instituto em suas respectivas Constituições.

\subsubsection{O mecanismo da Constituição de Weimar}

Cumpre observar, por fim, que o art. 41 da Constituição de Weimar também previa uma forma de revogação de mandato do Chefe do Poder Executivo. Por proposta de um terço do Reichstag, por meio de votação, o presidente poderia ser destituído do $\operatorname{cargo}^{155}$.

Realizada a consulta, a revogação do mandato poderia se concretizar com a queda do presidente ou com sua manutenção no posto, nesse caso, com a renovação do mandato e resgate da confiança popular. ${ }^{156}$

\subsection{A configuração jurídica do Recall}

\subsubsection{Direito de participação e soberania popular}

O recall, como visto, nos Estados Unidos da América do Norte, foi introduzido nas legislações estaduais e locais, utilizado para fiscalizar os mandatos políticos das autoridades públicas, para aproximação entre representante e representado, e também com o objetivo de tornar a Administração Pública menos corrupta e mais eficiente.

Por outro lado, na União Soviética e nos países a ela politicamente subordinados, a revogação do mandato foi utilizada como um dos instrumentos dos partidos para viabilização do ideal socialista e manutenção do poder. ${ }^{157}$

\footnotetext{
${ }^{155}$ TEIXEIRA, J. H. Meirelles. op. cit., p. 479.

${ }^{156}$ XIFRA HERAS, Jorge apud Paulo BONAVIDES, Paulo. op. cit., p. 292.

${ }^{157}$ Segundo Darcy Azambuja, os partidos socialistas da Europa faziam com que o deputado, ao ser eleito, deixasse em poder da direção do partido sua renúncia, com a data em branco, para ser enviada ao parlamento na hipótese de não-cumprimento das determinações políticas (AZAMBUJA, Darcy. op. cit., p. 234).
} 
Além de ser originariamente uma forma de controle do poder político e de aproximação entre eleitor e eleito, o recall, hoje, possui outros fundamentos jurídicos.

Pode-se afirmar, em primeiro lugar, que, como forma de participação popular que é, o recall, assim como outros mecanismos democráticos, encontra fundamento na Declaração dos Direitos dos Homens de 1948, documento este redigido pela Organização das Nações Unidas que proclamou, após as atrocidades cometidas durante a Segunda Grande Guerra, os direitos fundamentais do ser humano.

Dentre os diversos direitos consagrados na Declaração, o art. 21 prevê o direito de participação política, estatuindo que "Todo ser humano tem o direito de fazer parte no governo de seu país, diretamente ou por intermédio de representantes livremente escolhidos". Além disso, o mesmo dispositivo prevê também que "a vontade do povo será a base da autoridade do governo; esta vontade será expressa em eleições periódicas e legítimas, por sufrágio universal, por voto secreto ou processo equivalente que assegure a liberdade de voto". ${ }^{158}$

Com a Declaração de 1948, o direito de participação (tanto direta como indireta) no governo passa a ser reconhecido como direito humano fundamental, exigência da própria dignidade da pessoa humana. ${ }^{159}$ A partir daí os sistemas jurídicos dos Estados Democráticos passaram a inserir em suas Constituições o direito de participação política (direta e indireta) como fundamento dos regimes políticos dos Estados.

Assim, o recall, nos dias atuais, além de ser mecanismo de controle do poder e de aproximação entre eleitores e eleitos, bem como de eficiência da máquina administrativa, é também um instituto que encontra fundamento no direito de participação (elemento que constitui a dignidade humana), consagrado pela Declaração dos Direitos dos Homens.

O direito de participação, por sua vez, está relacionado com o princípio da soberania popular, que é também um outro fundamento do recall. As regras de governo e a

\footnotetext{
${ }^{158}$ NAÇÕES UNIDAS. Declaração dos Direitos Humanos. Disponível em: <http://www.onubrasil.org.br/documentos_direitoshumanos.php>. Acesso em: 16 jan. 2009.

${ }^{159}$ Sobre a proclamação dos direitos fundamentais pela Declaração dos Direitos dos Homens de 1948, Dalmo de Abreu Dallari observa que, "Contendo trinta artigos, a Declaração é precedida de um preâmbulo, onde se diz que a Assembleia Geral das Nações Unidas proclama os direitos fundamentais. É bem expressivo esse termo, pois torna evidente que não há concessão ou reconhecimento dos direitos, mas proclamação deles, significando que sua existência independe de qualquer vontade ou formalidade. Assim sendo, tratando-se de direitos fundamentais inerentes à natureza humana, nenhum indivíduo ou entidade, nem os governos, os Estados ou a própria Organização das Nações Unidas, têm legitimidade para retirá-los de qualquer indivíduo" (DALLARI, Dalmo de Abreu. Elementos de teoria geral do Estado, cit., p. 212).
} 
organização estrutural do ordenamento jurídico são constituídas com base nesse princípio. A possibilidade de revogar o mandato fundamenta-se, portanto, na fonte do poder político que é o povo, soberano para decidir sobre o seu destino, e não encontra o seu fundamento na teoria do mandato representativo e nos empecilhos da velha questão da soberania nacional. O fundamento é a participação direta prevista na Declaração das Nações Unidas e, no caso do Brasil, na Constituição Federal.

A partir da Segunda Grande Guerra houve uma ruptura nas velhas justificativas e teorias democráticas. O direito de participação política tomou vulto e junto com a soberania popular passaram a abrir um novo caminho, não se tratando de uma questão ideológica, de posições esquerdistas ou direitistas, e sim de uma questão ligada diretamente a um direito fundamental, o da dignidade da pessoa humana, direito esse, inclusive, considerado inalterável pelas Constituições democráticas.

\subsubsection{Direito político}

Os direitos políticos, segundo José Afonso da Silva ${ }^{160}$, "Consistem na disciplina dos meios necessários ao exercício da soberania popular”.

Daniela Romanelli da Silva assevera que os direitos políticos "correspondem ao conjunto de normas jurídicas que qualificam os cidadãos a lutar pelo poder, a formar vontades coletivas e ater essas vontades acolhidas pelo Estado" ${ }^{161}$ e, segundo a mesma autora, são classificados em direitos políticos originários e direitos políticos imanentes. ${ }^{162}$

No trilho da classificação acima proposta, os direitos políticos originários são os direitos políticos propriamente ditos, decorrentes do poder soberano do povo, que consistem na faculdade conferida aos cidadãos para que decidam assuntos relacionados à composição dos poderes do Estado para que deliberem diretamente sobre a proposição ou aprovação de atos normativos. Caracterizam-se como direitos políticos originários o direito de eleger representantes, o direito de participar de plebiscitos e referendos, o direito de iniciar o processo legislativo mediante a subscrição de um determinado número de assinaturas no projeto de lei, o direito de vetar leis e o de revogar mandatos. ${ }^{163}$

\footnotetext{
${ }^{160}$ SILVA, José Afonso da. Curso de direito constitucional positivo. São Paulo: Malheiros Ed., 2005. p. 345.

${ }^{161}$ SILVA, Daniela Romanelli da. Democracia e direitos políticos. São Paulo: Instituto de Direitos Políticos, 2005. p. 136.

${ }^{162}$ Id. Ibid., p. 175 e ss.

${ }^{163}$ Id. Ibid., p. 175-178.
} 
Portanto, os direitos políticos originários são os direitos conferidos ao cidadão, por uma determinada legislação, que lhe permite exercer o direito de voto, de externar sua opinião nos plebiscitos e referendos, o direito de manifestar sua concordância com determinado texto de emenda constitucional ou projeto de lei, o direito de exercer o poder de veto e o direito de decidir, por meio do voto, se determinado representante (ou representantes) deverá permanecer ou não em um certo cargo ou função pública. Essa última hipótese trata dos institutos do recall e do Abberufungsrecht suíço.

Com relação a essa última espécie de direito político originário, Daniela Romanelli da Silva ${ }^{164}$ afirma que "a revogação de mandato é um direito político originário, porquanto permite que o conjunto de cidadãos impeça que um mandatário que não cumpre a sua função a contento permaneça no poder". E diz ainda que "tal decisão popular condiciona a vontade do Estado, na medida em que cria condições para que outros tomem as principais decisões às quais todos estão submetidos". 165

Os direitos políticos imanentes, por sua vez, ainda de acordo com a classificação acima mencionada, são faculdades conferidas às pessoas registradas no corpo eleitoral que permitem participar de forma mais ativa da vida pública, por meio de filiação partidária, candidatura a cargos eletivos (elegibilidade), exercício de cargos ou função pública (acesso a cargos e funções públicas) e o direito de exercer o controle dos atos dos agentes públicos por meio de propositura de ação popular. ${ }^{166}$

O recall, objeto deste trabalho, qualifica-se como direito político originário, uma vez que, de fato, o instituto trata de assuntos relacionados à composição dos poderes do Estado (direito de participar de decisão coletiva sobre a permanência ou não de determinado agente público em um cargo ou função pública), contudo, por outro lado, o instituto também se manifesta como um mecanismo de controle do poder político (que é uma das características dos direitos políticos imanentes), pois ao decidir se o mandato será revogado ou não, o indivíduo exerce o poder de fiscalização e avalia a responsabilidade política do representante, culminando numa espécie de sanção (penalidade) ou absolvição deste, o que indica também certo caráter sancionador do instituto, que será avaliado mais adiante.

\footnotetext{
${ }^{164}$ SILVA, Daniela Romanelli da. op. cit., p. 207.

${ }^{165}$ Id., loc. cit.

${ }^{166}$ Id. Ibid., p. $375-377$.
} 


\subsubsection{Mecanismo de democracia semidireta}

Há, no Direito Constitucional, doutrinadores que escreveram sobre a democracia e seus tipos, levando em consideração a forma como o povo participa do poder.

Partindo dessas concepções doutrinárias, há três tipos de democracia: direta, representativa e semidireta.

O primeiro é qualificado por Georges Burdeau como mera curiosidade histórica e pode ser encontrada ainda hoje nos Cantões suíços de Glaris, Unterwalden e Appenzell ${ }^{167}$ e nas Open Town Meetings dos Estados Unidos da América.

A democracia representativa é aquela exercida por meio de mecanismos de representação política, com eleições periódicas e voto secreto.

Darcy Azambuja ${ }^{168}$ ensina que a democracia semidireta "é um sistema misto, que guarda as linhas gerais do regime representativo, porque o povo não se governa diretamente, mas tem o poder de intervir, às vezes, diretamente na elaboração das leis e em outros momentos decisivos do funcionamento dos órgãos estatais”.

A Suíça é a terra clássica da democracia semidireta, desenvolvida, ao lado da Landsgemeinde, na legislação federal e cantonal, de várias formas, dúcteis e eficientes. ${ }^{169}$ "Depois da Suíça, é por certo nos Estados Unidos onde o governo semidireto mais se desenvolveu. Os Estados da União Americana conheciam há muito o referendum constitucional, mas foi no século XX que, como uma reação aos desvirtuamentos do regime representativo, o adotaram para as leis ordinárias, ao lado da iniciativa popular e de uma outra forma de democracia semidireta, essa bem caracteristicamente ianque - o recall das decisões judiciárias". ${ }^{170}$

A democracia semidireta, portanto, possui elementos da democracia direta e da representativa $^{171}$, sendo o recall, foco deste estudo, um dos veículos desse tipo de democracia ao lado do referendo, do plebiscito, da iniciativa popular e do veto popular. ${ }^{172}$

\footnotetext{
${ }^{167}$ Trata-se da forma de democracia direta denominada Landsgemeinde (BURDEAU, Georges, Droit Constitutionnel et Institutions Politiques apud DALLARI, Dalmo de Abreu. Elementos de teoria geral do Estado, cit., p. 153).

${ }^{168}$ AZAMBUJA, Darcy. op. cit., p. 224.

${ }^{169}$ BARTHELEMY, Joséph; DUEZ, Paul. Traité de Droit Constitutionnel, Dalloz, 1933, apud AZAMBUJA, Darcy. op. cit., p. 225.

${ }^{170}$ AZAMBUJA, Darcy. op. cit., p. 226.

${ }^{171}$ SILVA, José Afonso da. op. cit., p. 136.

${ }^{172}$ Com base no direito comprado, Dalmo de Abreu Dallari ensina que o referendum é uma consulta à opinião pública para a introdução de uma emenda constitucional ou lei ordinária, quando há interesse público
} 
Como averbado no início desta tese, a democracia indireta, no Brasil, nos últimos vinte anos, tornou-se mais importante que a participação popular. Os mecanismos de democracia semidireta, por outro lado, não têm funcionado. O recall, nesse cenário, como instrumento dessa última espécie de democracia, serve para calibrar os problemas da democracia representativa, aproximando os eleitores de seus representantes, além de se caracterizar como mecanismo de controle da atuação das autoridades.

\subsubsection{Mecanismo de democracia participativa}

Em princípio, todo processo democrático é participativo. Democracia implica necessariamente participação.

Genericamente, a democracia participativa pode ser entendida como o conjunto de mecanismos de participação distinto da democracia indireta (que é aquela realizada por meio de representantes). Assim, qualquer forma de participação democrática que não seja pela forma indireta poderia ser considerada democracia participativa. No entanto, especificamente, democracia participativa consiste basicamente na utilização dos mecanismos de democracia semidireta acima mencionados, bem como no exercício do direito de ação popular.

Democracia participativa, portanto, restringe-se a esses poucos mecanismos de participação popular, acima mencionados.

$\mathrm{Na}$ democracia chamada participativa, o povo não toma decisões em reuniões coletivas, mas por meio de votação em algo concreto que é submetido à sua deliberação. $\mathrm{O}$ povo participa da decisão política do Estado, colaborando no processo de formação de vontade deste ente por meio do exercício do voto ${ }^{173}$ ou por meio de subscrição de um projeto lei, sendo que, no caso da ação popular, o cidadão eleitor não participa do processo decisório estatal, apenas exerce o controle dos atos das autoridades públicas mediante

envolvido. O plebiscito é uma consulta prévia à opinião popular. A iniciativa popular é o mecanismo que confere a um determinado número de eleitores a possibilidade de apresentar um projeto de emenda constitucional ou de lei para apreciação do Poder Legislativo. O veto popular, também conhecido como mandatory referendum, consiste na concessão de prazo aos eleitores, após a aprovação de um projeto de lei pelo Poder legislativo, para que eles possam requerer a aprovação popular. A lei não terá vigência enquanto perdurar esse prazo e havendo solicitação de um certo número de eleitores o projeto de lei continuará suspenso até que sejam realizadas novas eleições, momento esse em que os eleitores se manifestarão acerca da entrada em vigor do projeto de lei ou não (DALLARI, Dalmo de Abreu. Elementos de teoria geral do Estado, cit., p. 153-154).

${ }^{173}$ SILVA, José Afonso da. O sistema representativo, democracia direta e democracia representativa. Revista do Advogado, São Paulo, v. 23, n. 73, p. 99, nov. 2003. 
movimentação do aparato judiciário, para pleitear a anulação ou declaração de nulidade de atos lesivos ao patrimônio público.

Assim, o recall, além de integrar o que se chama de democracia semidireta, é também um típico mecanismo de democracia participativa.

\subsubsection{Mecanismo de controle do poder político}

Como já salientado, originariamente, nos Estados Unidos, a revogação do mandato político foi utilizada por determinadas populações locais para fiscalizar os representantes das comunidades que agiam em nome da coletividade.

No final do século XIX e na primeira década do Século XX, ressurge o instituto nos Estados Unidos, com destaque para os Estados de Oregon e Califórnia, neste último caso utilizado para combater os abusos econômicos e a corrupção desencadeada pela empresa ferroviária Southern Pacific Railroad.

O recall, desde que devidamente regulado para evitar abusos, possui uma extraordinária força como mecanismo de controle dos governantes, sejam eles deputados ou agentes políticos do Poder Executivo.

Nos Estados Unidos, especificamente, o instituto é um mecanismo consistente de controle, e dependendo do Estado da Federação, há previsão de sua utilização para destituição de autoridades do Executivo, Legislativo e Judiciário, diretores de escolas e até mesmo de qualquer servidor público, mesmo que não ocupe cargo eletivo. Essa ampla variação de sujeitos que podem ser submetidos ao mecanismo é um fenômeno típico da sociedade norte-americana, uma vez que os Estados têm autonomia para decidirem, da forma que lhes for mais conveniente, quem pode ser submetido ao recall e quais são as hipóteses em que ele pode ser aplicado.

Os Estados Unidos possuem forte tradição no que diz respeito à questão dos meios de controle do poder político. O próprio sistema federativo desse país foi criado levando em consideração essa idéia. O sistema de freios e contrapesos é um dogma e foi instituído nos Estados Unidos da América do Norte, por influência de Montesquieu, constituindo parte essencial do alicerce democrático desse país. ${ }^{174}$

\footnotetext{
${ }^{174}$ Segundo Dalmo de Abreu Dallari, "fortemente influenciados por MONTESQUIEU, os constituintes norteamericanos acreditavam fervorosamente no princípio da separação de poderes, orientando-se por ele para a
} 
O recall aparece, dentro do sistema jurídico, como uma forma de controle dos atos e abusos das autoridades públicas, obviamente, fora do controle interno do governo, porém, afinado com os princípios democrático e republicano ${ }^{175}$, uma vez que quem exerce a fiscalização são os próprios eleitores, que acompanham o comportamento de seus representantes.

O recall, portanto, além de ser uma forma de aprimoramento da relação entre representado e representante, é também um excepcional mecanismo de fiscalização dos atos das autoridades públicas, principalmente quando o sistema constitucional de freios e contrapesos não cumpre a sua missão.

$\mathrm{Na}$ sua origem norte-americana, portanto, verifica-se que o instituto possuía um nítido caráter de controle do poder político, o qual permanece presente até os dias de hoje, sendo essa uma de suas principais características. E essa característica, por sua vez, está intimamente relacionada à questão da responsabilidade daquele que exerce o mandato político. Hoje, o recall não representa um retorno ao mandato imperativo. Trata-se de mecanismo de controle que encontra fundamento na questão da responsabilidade do representante, que tem o dever de prestar contas e de permitir que seus atos sejam fiscalizados pelos eleitores. ${ }^{176}$

Ao lado de todos os fundamentos que foram elencados até aqui, a questão da responsabilidade do mandatário é hoje o principal fundamento do recall. A Responsabilidade está dentro do novo contexto do controle do poder político. No Século XXI, com a efervescência dos direitos de quarta geração ${ }^{177}$, a personalização na escolha dos candidatos, a existência de problemas que envolvem, sem distinção, todos os seres humanos, como, por exemplo, as questões climáticas e ambientais, não há como existir

composição do governo da federação. Elaborou-se, então, o sistema chamado de freios e contrapesos, com os três poderes, Legislativo, Executivo e Judiciário, independentes e harmônicos entre si, não se admitindo que qualquer deles seja mais importante que os demais" (DALLARI, Dalmo de Abreu. Elementos de teoria geral do Estado, cit., p. 258).

${ }^{175}$ Citando o pensamento de James Madison, Dalmo de Abreu Dallari ensina que o governo republicano na sua origem norte-americana "é aquele que deriva todos os seus poderes, direta ou indiretamente, de todo o povo e que é exercido por pessoas que conservam seus cargos à disposição do mesmo povo, ocupando-os durante um período limitado ou enquanto observarem bom comportamento" (DALLARI, Dalmo de Abreu. O Estado Federal, cit., p. 26).

${ }^{176}$ Sobre esse aspecto, Geraldo Ataliba escreve que "na idéia de responsabilidade vêm envolvidas, necessariamente, as noções de prestação de contas e fiscalização dos mandatários pelos mandantes. Sem esses ingredientes, idoneamente formulados - e dotados de um instrumental que lhes assegure eficácia não se pode falar legitimamente em mandato, e nem, em consequiência, em república federativa (ATALIBA, Geraldo. República e constituição. São Paulo: Malheiros Ed., 1998. p. 91).

${ }^{177}$ Direitos de quarta geração são o direito à democracia, à informação e ao pluralismo. 
mandato legítimo sem responsabilidade, sem prestação de contas e sem fiscalização. A responsabilidade é o verdadeiro fundamento do recall.

Ao pé de todas essas considerações, frise-se, mais uma vez, que o recall não significa a volta do mandato imperativo. O mandato não é mais aquele representativo, livre, de duzentos anos atrás, nem partidário, apesar das recentes decisões prolatadas pelo Supremo Tribunal Federal e Tribunal Superior Eleitoral sobre a titularidade do mandato político. ${ }^{178}$ Os termos mais apropriados que se adaptam à nova realidade em que vivemos são "responsabilidade", "ética" e "democracia". O mandato republicano hoje é o mandato responsável, ético e democrático e é exatamente nesse contexto que se insere o recall nos dias atuais.

\subsubsection{Forma de expressão da oposição política}

Monica Herman Salem Cagianno ${ }^{179}$ elaborou excelente estudo sobre o fenômeno oposição, com amparo nas lições De Vergottini, Dahl e Duverger, no qual baseamos as ponderações que serão expendidas sobre o tema em questão.

Ensina a ilustre professora que o fenômeno oposição, como elemento formal do quadro institucional, vem da experiência anglo-saxônica, vinculado à evolução do parlamentarismo.

Até o final do século XVII, na Inglaterra, a oposição não era reconhecida institucionalmente pela ordem jurídica. Tal reconhecimento ocorre somente posteriormente na Dinastia Hanover, quando foi erigida ao nível constitucional, segundo a tese de que o exercício da oposição caberia à Câmara dos Comuns.

A partir do século XVII, com a consagração da separação funcional do poder estatal, a oposição passa a ser exercida dentro do próprio governo, integrando a ordem jurídica como forma de limitação e controle entre os poderes.

Posteriormente, assim que os partidos políticos passaram a ter importância na vida política assumindo formas diferentes de atuação, com o passar do tempo, a oposição

\footnotetext{
${ }^{178} \mathrm{O}$ sistema democrático brasileiro fundamenta-se na participação indireta e direta, nos termos do parágrafo único do art. $1^{\circ}$ da Constituição Federal. Ao mesmo tempo em que o sistema democrático é representativo, ele também é fundamentado na soberania popular. Portanto, o mandato, no Brasil, não pode ser simplesmente fundamentado na antiga tese da soberania nacional, uma vez que o elemento "soberania popular", contido no nosso sistema jurídico, traz uma nova perspectiva para o mandato.

${ }^{179}$ CAGGIANO, Monica Herman Salem. Oposição na política: propostas para uma rearquitetura da democracia, cit., p. 11-23; 95-99.
} 
adquiriu novas roupagens. Dentro da concepção de partido único, assume uma atuação dentro da própria agremiação político-partidária. No sistema inglês do two parties system, a oposição assume um caráter institucional de função pública, atuando de forma responsável, a ponto do chefe do partido minoritário receber salários dos cofres públicos e de ser o líder oficial da oposição ao governo. No quadro multipartidário, por seu turno, a oposição assume um papel integrativo e no panorama dos partidos de massa perde-se o caráter integrativo, passando a exercer um papel de contínua mobilização política para conquistar diversos níveis de influência na esfera do poder.

Em que pese a considerável evolução do fenômeno, o reconhecimento do papel da oposição na democracia ainda não se consagrou de forma definitiva.

É interessante observar que a Constituição Portuguesa, no seu art. $114^{180}$, reconhece oposição como um direito, demonstrando um notável avanço do Direito Constitucional deste país.

Ainda de acordo com os ensinamentos de Monica Salem Herman Caggiano, hoje, basicamente, a oposição se manifesta no processo político de quatro formas distintas. Em primeiro lugar, por meio dos partidos políticos, sendo essa a forma mais usual e conhecida. Expressa-se também por intermédio de grupos e movimentos sociais, com especial destaque para os lobbies e organizações não-governamentais, bem como na esfera judicial mediante a utilização de writs constitucionais e, no caso, do Brasil, especialmente mediante o ajuizamento de ações populares. Por fim, manifesta-se a oposição por meio dos instrumentos de democracia semidireta, a exemplo do referendo, plebiscito, veto popular e do recall, objeto deste estudo. Com relação a essa última forma de expressão, a oposição, de forma independente das organizações intermediárias, interfere diretamente nas esferas do poder.

No contexto do recall norte-americano, a oposição se manifesta convencendo o eleitorado a interferir diretamente, por meio do voto, para manter ou destituir um

\footnotetext{
${ }^{180}$ Art. $114^{\circ}$ da Constituição de Portugal: “Art. 114 . (partidos políticos e direito de oposição): 1. Os partidos políticos participam nos órgãos baseados no sufrágio universal e directo, de acordo com a sua representatividade eleitoral. 2. É reconhecido às minorias o direito de oposição democrática, nos termos da Constituição e da lei. 3. Os partidos políticos representados na assembléia da República e que não façam parte do Governo gozam, designadamente, do direito de serem informados regular e directamente pelo Governo sobre o andamento dos principais assuntos de interesse público, de igual direito gozando os partidos políticos representados nas Assembleias Legislativas das regiões autônomas e em quaisquer outras assembleias designadas por eleição directa relativamente aos correspondentes executivos de que não façam parte". PORTAL do Governo. Disponível em: <http://www.portugal.gov.pt/Portal/PT/Portal/PT/Portugal/Sistema_Politico/Constituiçao/constituiçãop13.h tm>. Acesso em: 16 jan. 2009.
} 
representante político ou autoridade pública ou, ainda, raramente, para revogar decisões judiciais. ${ }^{181}$

O recall, portanto, como registra Monica Salem Herman Caggiano, “implica, de fato, uma função censora cometida aos eleitores, vinculando os governantes e impondolhes o respeito à opinião pública por meio da ameaça psicológica permanente de sua destituição". ${ }^{182}$

\subsubsection{Sanção de natureza política}

O mandato pode se extinguir naturalmente com a morte, renúncia ou término por cumprimento do prazo para seu exercício ou pode ser perdido por aquele que o exerce em decorrência de aplicação de uma sanção de natureza política.

Como resultado de medida punitiva, o mandato pode ser perdido pelo representante em decorrência de cassação, ação de impugnação de mandato eletivo, impeachment, infidelidade partidária e recall.

Cassação, no Brasil, constitui ato punitivo que pode advir da própria casa legislativa, nas hipóteses de conduta incompatível do parlamentar com o exercício da investidura política ou de falta de decoro parlamentar ou, ainda, sanção que pode ser aplicada pela Justiça Penal, nas hipóteses de condenação por crime funcional que acarrete a aplicação de pena acessória de perda ou inabilitação para a função pública. ${ }^{183}$

A ação de impugnação de mandato eletivo é uma ação prevista na Constituição Federal brasileira, especificamente no art. 14, na qual o mandato eletivo pode ser impugnado perante a Justiça Eleitoral, no prazo de quinze dias contados da diplomação, desde que haja provas de abuso de poder econômico, corrupção ou fraude, devendo tramitar em segredo de justiça.

\footnotetext{
${ }^{181}$ No caso recente da Bolívia (2008), que tecnicamente não pode ser considerado como recall (mas sim como um procedimento específico para revogação de mandatos inspirado no modelo socialista), o mecanismo chamado referendo revocatório, no meio de uma crise institucional, foi aprovado em maio de 2008 pelo Senado boliviano (composto em sua maioria pela oposição ao governo) para tentar destituir Evo Morales do cargo de Presidente da República.

${ }^{182}$ CAGGIANO, Monica Herman Salem. Oposição na política: propostas para uma rearquitetura da democracia, cit., p. 97.

${ }^{183}$ MEIRELLES, Hely Lopes. Direito municipal brasileiro. 12. ed. atual. por Célia Marisa Prendes e Márcio Schneider Reis. São Paulo: Malheiros Ed., 2001. p. 598.
} 
Impeachment, por seu turno, como ensina Paulo Brossard ${ }^{184}$, não obstante tenha sido considerado no passado com o instituto de natureza penal, ato disciplinar e providência administrativa, trata-se, no Brasil, assim como nos Estados Unidos e Argentina, de instituto de natureza política, decorrente de prática de crime de responsabilidade, e seu procedimento é desenvolvido e decidido pela respectiva Casa Legislativa, resultando na perda ou confirmação de um mandato político, mediante votação realizada pelos próprios parlamentares. ${ }^{185}$

Cabe ressaltar, ainda, que, no Brasil, a infidelidade partidária também pode ensejar a perda do mandato político, conforme decidido recentemente pelo Supremo Tribunal Federal e pelo Tribunal Superior Eleitoral.

Por fim, o recall possui também caráter sancionador, de índole política, bastando, para comprovação de tal natureza, verificar as hipóteses existentes para seu processamento no direito norte-americano, tais como prática de atos de corrupção, desvio de dinheiro público, perjúrio, condenação criminal e indiciamento durante o mandato, bem como incompetência administrativa, conforme será analisado mais à frente. ${ }^{186}$

Portanto, o recall, hoje, não é apenas uma simples forma de extinção do mandato pelo voto decorrente do humor do eleitorado e sim uma sanção aplicada pelo próprio corpo eleitoral em virtude da conduta antiética, ilícita ou incompetente da autoridade pública. O recall se aplica em decorrência de mau comportamento do agente público, por isso, possui caráter sancionador, da mesma forma como ocorrem nos outros

\footnotetext{
${ }^{184}$ BROSSARD, Paulo. O impeachment. Porto Alegre: Oficinas Gráficas do Globo, 1965. p. 72.

${ }^{185}$ Pontes de Miranda qualificava o impeachment como "medida que tem por fito obstar, impedir que a pessoa investida de funções públicas continue a exercê-las" (MIRANDA, Francisco Cavalcanti Pontes de. Comentários à Constituição de 1946. 2. ed. rev. e aum. São Paulo: Max Limonad, 1953. v. 2, p. 416). A maioria dos autores, a exemplo de Paulo Brossard e Themistocles Cavalcanti, entende que o impeachment possui natureza exclusivamente política. No entanto, Pontes de Miranda entende ter o instituto natureza penal e José Frederico Marques, por sua vez, natureza mista (política e penal). Manoel Gonçalves Ferreira Filho, por sua vez, com relação à forma, afirma que o impeachment possui natureza judiciária (cf. FERREIRA FILHO, Manoel Gonçalves. Curso de direito constitucional. 32. ed. rev. e atual. São Paulo: Saraiva, 2006. p. 163-164).

${ }^{186}$ No Estado de Minnesotta, nos Estados Unidos, por exemplo, para se deflagrar o recall é necessário que existam provas sobre mau comportamento ou prática de atos ilícitos da autoridade pública. De acordo com a Constituição desse Estado americano, antes da circulação da petição de recall (emitida para coleta de assinaturas), a Suprema Corte Estadual deve avaliar se os fatos alegados na petição são verdadeiros e se há motivos suficientes para submeter a autoridade pública ao procedimento de revogação popular. Assim, o mandato só chegará a ser revogado (submetido à decisão popular) se o Judiciário se manifestar previamente sobre as provas, o que corrobora a nossa opinião de que o recall possui um caráter punitivo. Constituição do Estado de Minnesotta: RECALL of State Elected Officials. A Proposed Minnesota Constitutional Amendment. Disponível em: <http://www.house.leg.state.mn.us/hrd/pubs/recall96.pdf>. Acesso em: 16 jan. 2009 e MINNESOTA CONSTITUTION. Article VIII. Impeachment and Removal from Office. Disponível em: <http://www.house.leg.state.mn.us/cco/rules/mncon/Article8.htm>. Acesso em: 16 jan. 2009.
} 
institutos acima mencionados, com a diferença essencial que quem instaura e decide o procedimento no caso do recall é o eleitorado.

\subsubsection{Recall e federalismo}

As antigas colônias inglesas conquistaram independência, abdicaram de parcela de sua soberania para formar uma confederação e, posteriormente, a federação.

Sobre o tema, preleciona Dalmo de Abreu Dallari:

O Estado Federal foi criado na América do Norte, no século XVIII, como consequiência da proclamação da independência das treze colônias da Inglaterra na América. Em 1776, foi proclamada a independência e desde então as antigas colônias passaram a ser Estados e celebraram um acordo para agirem juntos numa confederação, na qual cada um mantém sua independência e sua soberania. É como acontece hoje na ONU, onde os Estados são todos independentes e soberanos, mas se obrigam a obedecer regras de um tratado. Entretanto os Estados americanos logo perceberam que, se continuassem ligados apenas por aquele tratado, conhecido como Artigos da Confederação, todos ficariam muito fracos porque muitos não obedeceriam às regras da Confederação. Por esse motivo, realizaram um congresso, na cidade de Filadélfia, a fim de aperfeiçoar o tratado. Mas, em lugar de ficarem apenas no aperfeiçoamento, vários delegados dos Estados propuseram uma nova forma de acordo, pela qual todos aceitariam uma Constituição comum, criando uma união indissolúvel. Assim nasceu o Estado Federal. A federação, palavra que vem do latim foedue e que significa aliança, substituiu a confederação. ${ }^{187}$

Por diversos fatores, inclusive históricos, o elevado grau de descentralização política dos Estados tornou-se a principal característica da formação da federação norte-americana. ${ }^{188}$

\footnotetext{
${ }^{187}$ DALLARI, Dalmo de Abreu. A reforma constitucional e as novas competências dos Estados e Municípios. In: SEMINÁRIO PACTO FEDERATIVO E AS RELAÇÕES INTERGOVERNAMENTAIS. Curitiba. Anais... Curitiba: IMAP, 1995. p. 25.

${ }^{188}$ A história dos Estados Unidos mostra que o profundo sentimento de independência das colônias contribuiu para fortalecer o grau de descentralização política na federação. As populações das colônias sempre tiveram suas atenções voltadas para os assuntos locais, sem vínculo com outras comunidades. Nesse sentido, René David ensina que "as 13 colônias, até a Guerra da Independência, tinham vivido de modo quase inteiramente independente umas das outras, e não tinham entre si, por assim dizer, nada em comum: nem no que respeita à sua origem, nem ao seu povoamento, nem às suas convicções religiosas, nem à sua estrutura e aos seus interesses econômicos. Não existia entre elas nenhum elo político, independentemente do seu elo comum com a metrópole, nenhuma instituição comum as reunia antes da revolução (DAVID, René. op. cit., p. 461-462). De modo um pouco diverso, com base em ensinamentos de Munro, Oswaldo Aranha Bandeira de Mello afirma que, embora as colônias tivessem organizações políticas distintas e possuíssem história e tradições próprias, havia entre elas linhas comuns como, por exemplo, unidade de linguagem, bem como subordinação à mesma coroa, sendo que esses laços é que possibilitaram a união das coletividades vizinhas (MELLO, Oswaldo Aranha Bandeira de. Natureza jurídica do Estado Federal. São Paulo: Prefeitura Municipal de São Paulo, 1948. p.11). De qualquer forma, a União norte-americana se formou com base nessa característica da autonomia das entidades que estavam se reunindo por razões práticas.
} 
Como ensinou Bernard Schwartz ${ }^{189}$, a principal preocupação dos autores da Constituição Federal foi a de assegurar que o governo nacional que estava sendo instituído não fosse tão poderoso a ponto de, na prática, anular os Estados que comporiam a nação. Para atingir esse objetivo, procurou-se limitar o governo federal a uma lista específica de poderes enumerados essenciais ao seu funcionamento prático e, por outro lado, simultaneamente, procurou-se reservar todo o resto de autoridade aos Estados, que deveriam permanecer inalterados, como soberanias separadas, com exceção de quaisquer poderes cedidos à nação. A ideia de federalismo, conforme entendiam os fundadores da União Americana, baseava-se na posição coordenada e independente dos diferentes centros de governo. Cada qual deveria se limitar a sua própria esfera e, dentro desta, cada governo deveria ser independente do outro.

Com a décima emenda à Constituição dos Estados Unidos ${ }^{190}$, de 1791, a competência legislativa dos Estados tornou-se regra e a competência das autoridades federais, a exceção.

O Federalismo nasce como federalismo duplo (federalismo dual), no sentido de que "o Estado e a nação têm, cada um sua própria área exclusiva de autoridade". ${ }^{191}$

No século XX o dualismo do Estado Federal foi abandonado e no seu lugar surge o federalismo cooperativo, deixando de existir a igualdade entre os Estados e a nação, passando a se expandir fortemente a autoridade do governo federal mediante a regulamentação do comércio, o uso pelo Congresso de seu poder de tributação e gastos, e mediante a concessão de subvenções federais aos Estados. ${ }^{192}$

Apesar desse desequilíbrio de natureza econômica, os Estados continuam com sua autonomia política inalterada, podendo se autodeterminarem do modo que melhor lhes convier, desde que respeitados os princípios básicos da Federação. Com base nisso,

\footnotetext{
${ }^{189}$ SCHWARTZ, Bernard. O federalismo norte-americano atual: uma visão contemporânea. Tradução de Elcio Cerqueira. Rio de Janeiro: Forense, 1984. p. 9.

${ }^{190}$ Décima emenda à Constituição dos Estados Unidos: "Os poderes que a Constituição não delega aos Estados Unidos, e que não proíbe que os Estados exerçam, são reservados a cada um dos Estados, respectivamente, ou ao povo".

${ }^{191}$ SCHWARTZ, Bernard. op. cit., p. 27.

${ }^{192}$ Id. Ibid., p. 37-45. A partir do governo de Franklin D. Roosevelt (1933-1945) intensifica-se a ajuda do governo federal aos Estados-membros, por meio de programas e convênios, com destaque para ajuda financeira para os setores de saúde e bem-estar social (HORTA, Raul Machado, As novas tendências do federalismo e seus reflexos na Constituição brasileira de 1988. Revista do Legislativo, n. 25, p. 19-20, jan./mar. 1999. Disponível em: <http://www.almg.gov.br/RevistaLegis/Revista25/raul25.pdf>. Acesso em: 10 jan. 2009.
} 
organizam seus sistemas eleitorais, criando seus próprios códigos eleitorais, permitindo, por exemplo, mecanismos de democracia semidireta.

O recall foi instituído nos Estados Unidos observando essa característica da Federação norte-americana. Não é previsto em nível federal, apenas nos níveis estaduais e municipais. ${ }^{193}$

Foi nesse contexto que se introduziu o recall no direito norte-americano, observando a autonomia política dos Estados federados, com prioridade à política local, pois havia o entendimento de que nas cidades era mais fácil exercer o controle político sobre os governantes, conforme já salientado alhures. Não obstante, como observa Cronin $^{194}$, desde a instauração do recall no começo do século XX até os dias de hoje, o recall nacional (para as autoridades federais) é ocasionalmente sugerido, principalmente quando ocorrem escândalos, como, por exemplo, na época do Watergate, mas pouco se fez nesse sentido, apesar de a ideia contar com a simpatia da opinião pública. ${ }^{195}$

O recall, portanto, em qualquer situação e em qualquer ordenamento que vier a ser adotado, encontrará fundamento na soberania popular e nos direitos de participação política. É também mecanismo de democracia semidireta e de democracia participativa. Caracteriza-se como direito político originário e como forma de controle do poder político baseados no princípio da responsabilidade. ${ }^{196}$ Trata-se também de uma forma de perda do

\footnotetext{
${ }^{193}$ A Constituição norte-americana não faz qualquer referência aos Municípios e não assegura autonomia nem renda própria, a exemplo do que ocorre no sistema constitucional brasileiro. A autonomia municipal nos Estados Unidos, no entanto, é reconhecida pelo Estado-membro a partir do instante em que o núcleo urbano atende a certas condições, em especial quando atinge um mínimo de população. A forma de Administração municipal varia de acordo com o Estado-membro e também de cidade para cidade. Pode ser exercida por um conselho, por uma comissão (cada membro cuida de uma determinada atividade), por um único indivíduo (nesse caso, chamado de mayor) que é assessorado por um conselho, por um sistema denominado federal analogy (semelhante à nossa Administração municipal) ou por um indivíduo denominado manager, que é contratado para administrar o município por um determinado período, podendo atuar, inclusive, nessas outras modalidades de Administração, havendo até cursos na Universidade de Harvard para formar indivíduos especializados em Administração municipal, que se qualificam como managers (MEIRELLES, Hely Lopes. op. cit., p. 48).

${ }^{194}$ CRONIN, Thomas E. op. cit., p. 132.

${ }^{195}$ Uma pesquisa de opinião feita em 1987 pela Gallup Organization, solicitada por Thomas E. Cronin, demonstrou haver apoio significativo para se apresentar uma proposta de emenda constitucional para permitir o recall dos membros do Congresso e até mesmo do Presidente da República. Segundo a referida pesquisa, $67 \%$ dos entrevistados no país afirmaram que gostariam que a Constituição Americana permitisse o recall dos membros do Congresso e $55 \%$ dos pesquisados preferiria que a Constituição fosse emendada para permitir o recall do presidente. (CRONIN, Thomas E. op. cit., p. 132.)

${ }^{196}$ Sobre a natureza jurídica do recall e de outros mecanismos de democracia semidireta, Meirelles Teixeira diz que, para os adeptos da teoria orgânica da soberania (constituindo a Nação mero órgão estatal), todas essas manifestações da vontade popular são atos do próprio Estado e, para os adeptos da teoria da soberania nacional, geralmente adotada pelos Estados democráticos modernos, são manifestações da vontade do povo, da própria soberania nacional, no caso do recall, do exercício do poder eleitoral de eleger ou revogar mandatos políticos (TEIXEIRA, J. H. Meirelles. op. cit., p. 480).
} 
mandato decorrente de sanção política, ao lado de outros institutos, a exemplo do impeachment e da cassação. É forma de expressão da oposição, aproxima o eleitor do eleito e, portanto, aprimora a questão da representação política, além de ser mecanismo que pode ser adotado por diferentes entes federativos, com base na autonomia política destes, desde que observada a Constituição.

\subsubsection{Recall e sistemas eleitorais}

Nos Estados Unidos da América do Norte, onde existe a figura do recall, o sistema eleitoral para os cargos do legislativo é baseado no sistema majoritário. ${ }^{197}$

Antes, porém, de adentrarmos na análise dos sistemas eleitorais, faz-se necessário estabelecer previamente certos conceitos.

\subsubsection{Definições prévias}

Segundo José Afonso da Silva ${ }^{198}$, “A eleição, modernamente, não passa de um concurso de vontades juridicamente qualificadas visando operar a designação de um titular de mandato eletivo" e "O conjunto de técnicas e procedimentos que se empregam na realização das eleições, destinados a organizar a representação do povo no território nacional, se designa sistema eleitoral".

Dieter Nohlen" 199 entende sistemas eleitorais como "o modo pelo qual os eleitores expressam em votos sua preferência partidária ou pessoal, a qual será traduzida em mandatos".

Os sistemas eleitorais são compostos de técnicas e procedimentos instituídos em lei para estabelecer a representação dentro de determinados espaços geográficos. Pretende-se, com a adoção de um determinado sistema eleitoral, que haja efetivamente representação. Nenhum sistema é perfeito, mas em todos eles é possível encontrar uma justificativa para sua adoção. Um sistema jurídico pode dar preferência à proteção das minorias, às vezes pode procurar resultados mais práticos e, outras vezes, pode buscar

\footnotetext{
${ }^{197}$ No Brasil, os cargos para o Legislativo são preenchidos pelo sistema de representação proporcional, exceto para o caso das eleições para o Senado Federal, no qual o sistema é o majoritário por maioria simples.

${ }^{198}$ SILVA, José Afonso da. Curso de direito constitucional positivo, cit., p. 368.

${ }^{199}$ NOHLEN, Dieter. Wahlsysteme und Systemwechsel in Osteuropa apud SILVA, Luís Virgílio Afonso da. Sistemas Eleitorais. Tipos, efeitos jurídico-políticos e aplicação ao caso brasileiro. São Paulo, Malheiros Editores, 1999, p. 36.
} 
maior proximidade entre representantes e representados. Mas, de qualquer forma, as idéias de representação e mandato sempre estarão por detrás dos sistemas eleitorais.

Além disso, o sistema eleitoral atua em conjunto com o sistema de partidos, constituindo, ambos, os mecanismos pelos quais ocorrem a coordenação, organização, instrumentação e expressão da vontade popular na escolha dos representantes. ${ }^{200}$

\subsubsection{A classificação dos sistemas eleitorais}

Os sistemas eleitorais podem ser classificados em majoritário e proporcional. Fala-se também em sistema misto, como uma terceira espécie, para designar o sistema alemão $^{201}$, o qual, na verdade, conforme será demonstrado mais à frente, enquadra-se no sistema proporcional.

O sistema majoritário é aquele em que "a representação, em dado território (circunscrição ou distrito), cabe ao candidato ou candidatos que obtiverem a maioria (absoluta ou relativa) dos votos". 202

Pinto Ferreira ${ }^{203}$ ensina que o sistema majoritário pode ser puro (ou simples) ou em dois turnos. O primeiro corresponde à maioria relativa, quando o candidato mais votado é proclamado eleito e o segundo ocorre quando o candidato deve obter a maioria absoluta (metade mais um dos votos) e se não a obtiver, procede-se a uma nova votação, chamada pelos franceses de scrutin de ballotage, que se resolverá pela maioria simples.

O sistema majoritário, nas lições de José Afonso da Silva ${ }^{204}$, também se conjuga com o sistema de eleições distritais, havendo neste último, distritos uninominais pelos quais os eleitores escolhem entre candidatos individuais em cada partido (um candidato por partido) e os distritos plurinominais (chamado também de sistema de listas) pelos quais cada partido apresenta uma lista de candidatos (com uma pluralidade de nomes) para a escolha dos eleitores distritais. Além disso, por princípio, em cada distrito se elege apenas um candidato, considerando-se derrotados os demais. ${ }^{205}$

\footnotetext{
${ }^{200}$ SILVA, José Afonso da. Curso de direito constitucional positivo, cit., p. 369.

${ }^{201}$ O sistema existente no México também é chamado de sistema misto. Cf. SILVA. José Afonso da. op. cit., p. 369.

${ }^{202}$ Id. Ibid., p. 370.

${ }^{203}$ FERREIRA, Luiz Pinto. op. cit., t. 1, p. 647.

${ }^{204}$ SILVA, José Afonso da. Curso de direito constitucional positivo, cit., p. 370.

${ }^{205}$ Luís Virgílio Afonso da Silva afirma que "as expressões sistema distrital e voto distrital são absolutamente carentes de valor distintivo entre os sistemas eleitorais, pois referem-se apenas a uma das suas variáveis - o
} 
O paradigma da representação majoritária é o sistema eleitoral do Reino Unido, constituído pelo sistema de maioria simples, em distritos uninominais, consolidado e aceito pela maioria dos britânicos. Sua origem remonta aos meados do século XIII, tendo sofrido algumas alterações ao longo dos séculos até chegar ao sistema hoje existente. ${ }^{206}$

Como já destacado, os Estados Unidos também adotam o sistema majoritário, com exceção das eleições presidenciais, que seguem um método de eleição indireta, distinto do método comum, no qual o Presidente e Vice-Presidente da República são escolhidos por um colégio eleitoral e não diretamente pelo eleitorado.

Sobre esses países, anota Pinto Ferreira ${ }^{207}$ que "o caráter comum dos sistemas majoritários, adotado na Inglaterra e nos Estados Unidos, consiste em que eles apenas asseguram uma representação aproximada das maiorias, elegendo tão só os representantes mais votados nas circunscrições eleitorais, os demais candidatos sendo derrotados. Apesar disso, ainda se assegura uma representação das minorias, posto que sempre o partido majoritário no país pode ser vencido em algumas circunscrições, que elegem os representantes da minoria".

No Brasil, de acordo com o Sistema Constitucional vigente, o sistema majoritário se aplica a todos os Chefes dos Executivos da Federação ${ }^{208}$ (Presidente da República, Governador do Distrito Federal, Governadores Estaduais e Prefeitos Municipais) e aos Senadores representantes dos Estados-membros da Federação. ${ }^{209}$

distrito -, o que não é suficiente para se distinguir se o sistema é majoritário ou proporcional. São Sistemas distritais, dessa forma, tanto o proporcional brasileiro, no qual os distritos equivalem aos Estados federados, quanto o majoritário inglês, com seus distritos uninominais. No Brasil, no entanto, sistema distrital ficou sendo sinônimo de sistema majoritário em distritos uninominais, o que não é correto. Parece que tal equívoco vem da falsa contraposição feita entre distrito, que seria a delimitação territorial onde se realizam aquelas eleições nas quais o vencedor é somente o candidato mais votado, e circunscrição, que seria a delimitação onde são realizadas as eleições proporcionais com vários eleitos no mesmo espaço físico. Não há, contudo, qualquer fundamento para essa contraposição, porquanto as palavras distrito e circunscrição, sem qualquer qualificação, significam tão-somente uma delimitação eleitoral que define quais votos serão levados em consideração para a atribuição deste ou daquele mandato, independente do sistema eleitoral adotado, do número de eleitos ou de candidatos por partido, sendo, portanto, sinônimas" (SILVA, Luís Virgílio Afonso da. Sistemas eleitorais: tipos, efeitos jurídico-políticos e aplicação ao caso brasileiro. São Paulo: Malheiros Ed., 1999. p. 26).

${ }^{206}$ Id. Ibid., p. 99.

${ }^{207}$ FERREIRA, Luiz Pinto. Princípios gerais do direito constitucional moderno. 3. ed. rev. e ampl. e atual. São Paulo: Saraiva, 1975. t. 2, p. 647.

${ }^{208}$ Para os Municípios com menos de duzentos mil eleitores exige-se maioria relativa. Para os demais casos (Municípios com mais de duzentos mil eleitores, Estados e em nível nacional), a eleição é por maioria absoluta e, caso não seja atingida, faz-se um segundo turno, que se resolve por maioria relativa entre os dois candidatos mais votados.

${ }^{209} \mathrm{Na}$ hipótese dos Senadores, a eleição se resolve por maioria relativa. 
Quanto ao sistema de representação proporcional, Monica Herman Salem Caggiano $^{210}$ ensina que o núcleo central do mecanismo desse sistema "reside, essencialmente, em assegurar a cada uma das agremiações partidárias uma representação, se não matematicamente, ao menos, sensivelmente proporcional à sua real importância no contexto político".

Na mesma linha, José Afonso da Silva ${ }^{211}$ assevera que o sistema de representação proporcional ou simplesmente proporcional é aquele em que a representação, em determinado território (ou circunscrição), deve ser distribuída proporcionalmente às correntes ideológicas ou de interesse integrada nos partidos políticos concorrentes, e que suscita dúvidas para se determinar quem pode ser considerado eleito e o número de eleitos por partido. Essas dúvidas, por sua vez, são resolvidas pela determinação do número de votos válidos, o quociente eleitoral, o quociente partidário, a técnica de distribuição de restos ou sobras.

No Brasil, adota-se o sistema de representação proporcional para a eleição dos Deputados Federais, Deputados Distritais, Estaduais e Vereadores.

Por fim, fala-se também em sistema misto para qualificar o sistema eleitoral existente na Alemanha.

No sistema alemão há a reunião de elementos dos sistemas majoritários e proporcionais, por isso, é denominado corriqueiramente de sistema misto. É chamado também de "sistema de eleição proporcional personalizado"212 . Nesse sistema procura-se combinar "o princípio decisório da eleição majoritária com o modelo representativo da eleição proporcional, posto que divide cada voto em duas partes, computa-os em separado, elegendo-se a metade dos Deputados por circunscrições distritais e a outra metade em função de listas de base estadual". ${ }^{213}$

$\mathrm{Na}$ Alemanha, cada Estado é dividido em tantos distritos quantos forem os lugares a serem preenchidos. Cada um dos partidos apresenta um candidato por distrito e uma lista partidária para todo o Estado. O eleitor escolherá primeiro um dos candidatos do distrito, assinalando um nome e depois vota em uma das listas partidárias, escolhendo uma legenda. Para se calcular o número de cadeiras que serão dos partidos políticos, leva-se em

\footnotetext{
${ }^{210}$ CAGGIANO, Monica Herman Salem. Sistemas eleitorais x representação política, cit., p. 150.

${ }^{211}$ SILVA, José Afonso da. Curso de direito constitucional positivo, cit., p. 371.

${ }^{212}$ Id. Ibid., p. 376.

${ }^{213}$ NOHLEN, Dieter apud Id. Ibid., p. 376.
} 
consideração o percentual de votos obtidos pela legenda. Após esse cálculo, verifica-se quantos candidatos cada partido conseguiu eleger por distrito e quantos conseguiu pelo sistema de lista. ${ }^{214}$

O resultado do sistema alemão é a distribuição dos mandatos de acordo com a votação de cada partido, ou seja, de acordo com a força de cada partido político obtida nas urnas, por isso, é considerado um sistema proporcional e não misto. ${ }^{215}$

\subsubsection{Prós e contras dos sistemas eleitorais}

Com relação ao sistema majoritário em distritos, que ficou popularmente conhecido por aqui como voto distrital, com divisões do território geográfico em distritos ou circunscrições menores para determinação da representação política, existem elogios e críticas a tal sistema.

Quanto aos aspectos favoráveis, pode-se dizer que o candidato deverá possuir um vínculo real com a região pela qual irá se candidatar (o eleitor saberá em quem está votando, quais são os antecedentes do candidato e terá condições de saber se o candidato está falando a verdade), a campanha para o candidato será menos onerosa e sacrificante, há uma aproximação maior entre representante e representados o que possibilita a estes exercer um controle maior (no sentido de fiscalização) do representante, facilita a instauração do recall ("pois é mais exeqüível convocar os eleitores, dentro do distrito, para avaliar o desempenho de um deputado e revogar-lhe o mandato, se for o caso" ${ }^{216}$ ), diminui a frustração dos eleitores com relação à questão do "sentir-se representado" e favorece a estabilidade governamental. $^{217}$

Quanto aos aspectos desfavoráveis, fala-se que o sistema majoritário em distritos tende a prejudicar as minorias, favorece o bipartidarismo, pode gerar problemas com a demarcação das áreas, regionaliza as questões políticas e dá muito poder aos

\footnotetext{
${ }^{214}$ SILVA, José Afonso da. Curso de direito constitucional positivo, cit., p. 376.

${ }^{215}$ SILVA, Luís Virgílio Afonso da. op. cit., p. 81.

${ }^{216}$ CUNHA, Sérgio Sérvulo da. O que é voto distrital. Porto Alegre: Sergio Antonio Fabris, 1991. p. 33-34.

${ }^{217}$ Além de indicar a simplicidade, a estabilidade governamental e a menor onerosidade da campanha como aspectos favoráveis do sistema majoritário, Monica Herman Salem Caggiano assevera que "a técnica majoritária viabiliza um contato mais estreito a nível de representante/representado, possibilitando aos candidatos um conhecimento mais profundo e real dos peculiares interesses do corpo eleitoral e de cada um de seus componentes, fenômeno que, a seu turno, autoriza a cobrança quanto à conduta política do candidato vitorioso, por meio de um acompanhamento mais efetivo de sua atuação por parte dos eleitores" (CAGGIANO, Monica Herman Salem. Sistemas eleitorais x representação política, cit., p. 146).
} 
burocratas dos partidos políticos ${ }^{218}$. Ou seja, são os mesmos problemas que existem há séculos no Reino Unido e nos Estados Unidos da América do Norte e que são aceitos em geral pelos povos desses países.

A adoção de um sistema parecido com o da Alemanha tende a diminuir o impacto desses aspectos desfavoráveis.

Já o sistema de representação proporcional, pelo aspecto positivo, tende a não prejudicar as minorias, pois conduz a resultados mais equitativos e produz a representação dos vários seguimentos da sociedade. ${ }^{219}$ Por sua vez, pelo aspecto negativo, há o problema do poder econômico (pois o sistema dentro de um grande território gera necessariamente altos gastos, o que aproxima os candidatos dos donos do dinheiro, o que pode favorecer a corrupção), o distanciamento entre representantes e representados, o problema da falta de vínculo e da falta de compromisso. ${ }^{220}$

A nosso sentir, o recall pode até funcionar no sistema proporcional, mas desde que seja em nível municipal para pequenos e médios Municípios. Nos demais casos, no sistema de representação proporcional, o custo de um procedimento de recall e a dificuldade natural decorrente do elevado número de eleitores envolvidos tornam praticamente inviável a utilização desse mecanismo nos grandes Municípios, nos Estados e em nível nacional. No sistema majoritário em distritos, no entanto, o recall passa a ser um instrumento viável em todos os níveis da Federação. Esse tema será retomado ao final desta tese.

\footnotetext{
${ }^{218}$ CUNHA, Sérgio Sérvulo da. op. cit., p. 23-40.

${ }^{219}$ Acerca dos pontos favoráveis das técnicas proporcionais, Monica Herman Salem Caggiano observa que "A sua principal virtude, de conduzir a resultados mais equitativos, é a primeira das facetas destacadas por seus defensores. Com efeito, cunhada a partir de equações matemáticas cujo objetivo é a repartição das cadeiras na exata proporção do volume de votos atribuídos a cada uma das agremiações partidárias, fica assegurada certa representatividade a esses grupos. E a possibilidade de expressão das várias e diversificadas forças políticas concorreria, assim, para que a decisão política, da maioria dos deputados eleitos, representasse, de forma mais fiel, a vontade da maioria dos eleitores (CAGGIANO, Monica Herman Salem. Sistemas eleitorais $x$ representação política, cit., p. 165).

${ }^{220} \mathrm{Karl}$ Loewenstein indicou outros aspectos negativos do sistema proporcional, tais como a mecanização do processo político, a dificuldade de formação de governos estáveis e o alijamento dos eleitores da política em decorrência do domínio do processo eleitoral pelos partidos políticos (LOEWENSTEIN, Karl apud CAGIANNO, Monica Herman Salem. Sistemas Eleitorais X Representação Política. Tese de doutorado apresentada à Faculdade de Direito da Universidade de São Paulo. São Paulo, 1987. p. 165).
} 


\subsection{Os aspectos desfavoráveis do recall}

Acerca das polêmicas que o recall suscita, André Hauriou ${ }^{221}$ afirma que o instituto levanta uma série de questões, passando por quase todos os temas do Direito Constitucional, tais como governo representativo, governo direto, teoria do mandato representativo e responsabilidade dos agentes públicos. No entanto, para Hauriou existem dois aspectos sensíveis que o recall desperta. O primeiro de ordem política e o segundo de ordem jurídica.

Quanto à questão política, dentre as críticas feitas por Hauriou, destacam-se as seguintes: (i) o direito de revogação encontra-se diretamente relacionado ao governo direto e, ao mesmo tempo, é uma negação razoavelmente consciente do regime representativo; (ii) o direito de revogação vai contra os homens e não contra os atos destes e (iii) o direito de revogação aproxima-se muito do instituto do mandato imperativo, não sabendo definir o citado autor se esse fato tem por objetivo organizar o governo direto ou trazer a desorganização para o regime representativo. Quanto a esse último aspecto, Hauriou tece comentários negativos sobre o mandato imperativo e conclui, finalmente, que o grande defeito, do ponto de vista político, do procedimento de revogação popular é o de sacrificar a estabilidade governamental. ${ }^{222}$

No que concerne à questão jurídica, Hauriou afirma que, na visão dos publicistas americanos, o recall trata também da forma de organizar a responsabilidade dos agentes públicos. A visão dos americanos é de ordem prática. $\mathrm{O}$ agente público deve ser responsável diante do povo, que é o dono do negócio. O principal argumento dos americanos em favor do recall é que este procedimento permite a aplicação do "good business principle". A máquina administrativa é entendida pelos americanos como uma grande empresa na qual o povo seria o patrão e para o seu bom funcionamento seria necessário que o dono do negócio pudesse demitir seu funcionário cuja responsabilidade estivesse seriamente comprometida. A questão, segundo o juspublicista francês, é saber se a destituição dos agentes públicos pelo povo constitui um bom sistema de responsabilidade. Um bom método para isso seria distinguir se a revogação é aplicada aos membros do governo ou aos outros funcionários. Para ele, na medida em que aplicada aos membros do governo (governadores e secretários de Estado) a revogação popular tem o erro de não distinguir entre responsabilidade política e penal. O que causa censura no

\footnotetext{
${ }^{221}$ HAURIOU, André. op. cit., p. 67-75.

${ }^{222}$ Id. Ibid., p. 67-71.
} 
recall, para Hauriou, é que a aplicação aos agentes políticos é um mecanismo grosseiro, que não permite bem distinguir entre a responsabilidade política e a penal. Por outro lado, se o recall passar a ser examinado com o processo de responsabilidade aplicado aos funcionários ordinários, é impossível não fazer, uma vez mais, a observação de que se trata de um processo imperfeito. É preciso que o sistema empregado permita aplicar uma sanção adequada ao erro e é desejável que o processo não configure uma explosão de paixões populares, além de movimentar todo o sistema por algo que não valha a pena. Apresenta também o erro de colocar o funcionário culpado ao julgamento passional do povo. Mas, para ele, o sistema mostra seu caráter mais defeituoso, quando se opera o recall dos juízes, porque fere a independência e imparcialidade dos magistrados. ${ }^{223}$

Thomas E. Cronin ${ }^{224}$ observa que os críticos do recall alegam que o procedimento confere muito poder aos eleitores e que prejudica a independência e discrição necessárias ao representante. Ademais, as eleições são dispendiosas para os municípios e estados e, além disso, na maioria dos casos, não se exige que se investigue a verdade ou o mérito das acusações de má-conduta. O mesmo autor afirma também que os oponentes do recall duvidam que o cidadão médio tenha conhecimento e discernimento para tomar tal decisão política.

O mesmo autor diz que os críticos do recall ainda lançam mão de cinco argumentos contra o instituto. ${ }^{225}$

O primeiro deles seria que o pressuposto do recall é contrário aos princípios republicanos, especialmente à ideia de eleger bons legisladores e autoridades, que devem ter a chance de exercer seu mandato ou governar até as próximas eleições, quando então poderiam ser responsabilizados. De acordo com esse argumento, os eleitos precisam de tempo e independência para exercer suas funções. $\mathrm{O}$ recall enfraqueceria a estrutura e a prática do governo republicano, uma vez que o instituto estimula o pensamento de curto prazo em detrimento ao de longo prazo, havendo o risco de a autoridade pública agir de acordo com o que pareça aceitável para o povo em determinado momento, deixando de tomar medidas que sejam temporariamente impopulares, mas necessárias, devido ao receio de que grupos rivais possam utilizar o procedimento para destituí-lo do cargo. É nesse

\footnotetext{
${ }^{223}$ HAURIOU, André. op. cit., p. 71-75.

${ }^{224}$ CRONIN, Thomas E. op. cit., p. 127.

${ }^{225}$ Id. Ibid., p. 135-139.
} 
instante que o recall, segundo seus opositores, retira a independência e coragem de ação dos agentes públicos.

O segundo argumento contrário seria que o recall torna o cargo ou função pública menos atraente para a maioria dos indivíduos, uma vez que todo e qualquer agente público, por qualquer motivo, pode ser submetido ao procedimento de recall, o que o torna um mecanismo jurídico constante de intimidação das autoridades.

O outro argumento é no sentido de que as eleições de recall seriam polarizantes, dividem as comunidades e são sujeitas a uma série de abusos e consequências não-intencionais. Os procedimentos são eventos emocionais, amargos e, às vezes, podem até causar tumultos e, em vez de resolver problemas, aumentam as tensões, dividindo as comunidades.

O quarto argumento é que as eleições são confusas, frequentemente injustas e geram um fardo para os eleitores que devem se manter informados durante os mandatos dos políticos. O cidadão médio fica confuso, especialmente porque em muitas regiões o recall é instaurado sem a existência de provas sobre as acusações feitas às autoridades e, além disso, debates sérios sobre o mérito das acusações sequer podem ocorrer.

Por fim, há o argumento de que as eleições de recall são dispendiosas e desnecessárias. Tal aspecto seria um dos mais fortes contra o mecanismo, principalmente quando envolve um grande Município ou Estado. Além disso, o tumulto político e as despesas são desnecessárias, dado que há disposições que buscam o mesmo resultado para o processo de impeachment ou ações similares pelo Executivo ou Judiciário.

Esses são os argumentos contrários ao recall, segundo os críticos do mecanismo, de acordo com Thomas E. Cronin.

\subsection{Os aspectos favoráveis do recall}

Afirma Thomas E. Cronin ${ }^{226}$ que os defensores do recall elencam seis argumentos em prol do mecanismo.

O primeiro deles é que o recall garante a responsabilidade contínua das autoridades públicas, de tal forma que os eleitores não têm que aguardar até a próxima eleição para se livrarem de um agente público incompetente, desonesto, despreocupado ou

${ }^{226}$ CRONIN, Thomas E. op. cit., p. 133-135. 
irresponsável. Com a existência do recall as autoridades tendem a se manter alertas, honestas e preocupadas. Nesse contexto, o recall pode ser entendido com uma forma de compensação dos defeitos do governo representativo, visto que enquanto a iniciativa e o referendo são meras modificações de governo representativo, o recall é uma tentativa de tornar o governo mais representativo ao aumentar a sensibilidade das autoridades eleitas à vontade da maioria. Os defensores do instituto alegam também que os eleitores devem ter o direito de destituir os seus servidores públicos, da mesma forma que um administrador pode despedir um funcionário remunerado.

O recall também é um mecanismo que serve para verificar a existência de influências indevidas em interesses específicos. As autoridades públicas podem ser responsabilizadas pelos seus eleitores e não por aqueles que fizeram doação às campanhas eleitorais. O recall vai de encontro aos interesses específicos, o que leva as autoridades a considerarem as pessoas antes de qualquer troca de favores.

O terceiro argumento favorável é que o recall permite sejam concedidos mais mandatos às autoridades eleitas em razão do sistema de controle exercido, o que pode aumentar a eficiência dos agentes públicos, além de estes terem mais tempo para planejar e executar os projetos de governo. ${ }^{227}$

Os defensores alegam ainda que o mecanismo cria para a pessoa comum uma razão para manter-se informada sobre o governo durante o exercício do mandato. $\mathrm{O}$ instituto do recall aproxima o cidadão das questões públicas relevantes.

O recall serviria também como um mecanismo de alívio para as tensões e sentimentos exacerbados dos eleitores.

Finalmente, o recall oferece uma alternativa sensata ao impeachment. O grande problema deste processo é que os agentes públicos podem tentar frustrar as tentativas de instauração de procedimentos dessa natureza. No âmbito local, a resistência ou tentativas de burlar o impeachment podem ser até mais intimidadoras. A obtenção de relatórios e demais provas necessárias para o processo de impeachment podem ser extremamente difíceis ou até mesmo impossíveis. O recall garante um meio para o mesmo fim, sem todo o esforço e trabalho jurídicos necessários. No entanto, o uso prudente do recall exige que o

\footnotetext{
${ }^{227}$ Por outro lado, no pensamento inverso, o recall é também um meio de combater a concentração de responsabilidades e longos períodos de mandato dos agentes públicos incompetentes (Cf. WILCOX, Delos F. op. cit., p. 196 e ss).
} 
número de assinaturas seja razoavelmente alto para proteger as autoridades eleitas do mauhumor de pequenos grupos ou da simples oposição local.

A autora portuguesa Maria Benedita Malaquias Pires Urbano ${ }^{228}$ elenca como argumentos favoráveis ao instituto o fato de ele ser um meio de controle dos representantes, principalmente dos funcionários públicos; o de ser corolário lógico do direito de sufrágio, isto é, se o eleitor tem o direito de escolher o seu representante, por outro lado, tem o direito de destituí-lo caso entenda que tenha feito uma má escolha; e por ser um meio idôneo para manter um diálogo permanente entre representante e representado, obrigando aquele a ouvir constantemente o sentimento dos eleitores e a prestar contas da sua atividade.

Delos F. Wilcox, em 1912, apresentou como argumento favorável o fato de o recall dar ao povo o direito permanente de corrigir as escolhas equivocadas feitas no momento de seleção de seus agentes públicos. ${ }^{229}$

Outros argumentos favoráveis encontrados nos escritos do início do século XX, nos Estados Unidos da América do Norte, são que o povo pode forçar os legisladores a elaborarem as leis de seu interesse, os deputados se tornariam mais verdadeiramente representativos e que o mais venal dos legisladores pode atender aos anseios populares, devido ao receio de ser destituído do cargo ou função pública. ${ }^{230}$

Com relação a esses aspectos negativos e positivos do instituto, Cronin ainda registra que não há como comprovar que o recall tenha causado desinteresse pela função pública por parte das pessoas competentes, nem há como demonstrar que o mecanismo tenha melhorado a representação dos eleitores ou que tenha diminuído os casos de corrupção ou de irresponsabilidade. ${ }^{231}$

Certos dados sobre o recall, no entanto, merecem registro. Por exemplo, em Los Angeles, onde já ocorreram mais de quarenta e cinco casos, os eleitores rejeitam o recall com orientação política, preferindo sua utilização de acordo com as origens do instituto, i.e., para paralisar a má-conduta e deter a corrupção das autoridades públicas. Essa situação se reflete, em geral, nas demais localidades onde o mecanismo já foi

\footnotetext{
${ }^{228}$ URBANO, Maria Benedita Malaquias Pires. op. cit., p. 83.

${ }^{229}$ WILCOX, Delos F. op. cit., p. 196).

${ }^{230}$ HOAR, Roger Sherman. Advantages of the recall, July, 1909. In: SELECTED articles of the recall compiled by Julia E. Johnsen. Minneapolis: The H. W. Wilson Company, 1901. p. 22-23. Disponível em: $<$ http://www.archive.org/details/selectedarticles00johnrich>. Acesso em: 22 dez. 2008.

${ }^{231}$ CRONIN, Thomas E. op. cit., p. 145-146.
} 
utilizado. Além disso, o recall, nos Estados Unidos, tem alto índice de participação do eleitorado, geralmente superior às eleições regulares, e nas pequenas e médias comunidades o índice de participação é impressionante. ${ }^{232}$ Consta também que $75 \%$ dos casos de recall ocorreram nas Câmaras Legislativas locais e nas diretorias escolares. Nas cidades maiores e em nível estadual sua utilização é quase inexistente, principalmente em razão do elevado número de assinaturas que, geralmente, é exigido pelas legislações. ${ }^{233}$

O recall é a "arma por detrás da porta” que mantém as autoridades públicas sensíveis às necessidades da População. ${ }^{234}$

${ }^{232}$ CRONIN, Thomas E. op. cit., p. 143.

${ }^{233}$ Id. Ibid., p. 151.

${ }^{234}$ Id. Ibid., p. 155. 


\section{ANÁLISE COMPARATIVA DO RECALL NO DIREITO CONTEMPORÂNEO}

\subsection{O Recall no Direito norte-americano atual}

\subsubsection{Noção inicial}

Como já averbado alhures, o recall é um instituto que faz parte da história norte-americana e é praticado, hoje, principalmente em nível local. Não está previsto em âmbito nacional e seus resultados são pouco significativos em nível estadual.

\subsection{2. Âmbito de aplicação do recall na federação norte-americana}

Atualmente, dezoito Estados ${ }^{235}$ e o Distrito de Columbia possuem em suas legislações dispositivos sobre o recall. O Estado de Virgínia não adota o mecanismo, porém, permite que qualquer cidadão possa apresentar uma petição requerendo uma audiência judicial para promover a remoção de um agente público. ${ }^{236}$

O recall é também permitido para remoção de diretores de escolas e universidades públicas. Setenta e cinco por cento dos procedimentos levados a efeito nos Estados Unidos são praticados em nível local. ${ }^{237}$

\subsubsection{Espécies de recall}

Segundo Dalmo de Abreu Dallari ${ }^{238}$, nos Estados Unidos existem duas espécies de recall. A primeira é utilizada para revogar a eleição de um legislador ou funcionário eletivo e a segunda é o recall judicial, utilizado para revogar decisão judiciária monocrática ou de tribunal local (ou regional) que tenha negado aplicação de lei por motivo de inconstitucionalidade.

\footnotetext{
${ }^{235}$ Alaska, Arizona, California, Colorado, Georgia, Idaho, Kansas, Lousiana, Michigan, Minnesota, Montana, Nevada, New Jersey, North Dakota, Oregon, Rhode Island, Washington e Wisconsin.

${ }^{236}$ RECALL of State Officials. National Conference of State Legislatures - The Forum for America's Ideas. Disponível em: <http://www.ncsl.org/programs/legismgt/elect/recallprovision.htm>. Acesso em: 17 jan. 2009; RECALL of State Elected Officials. A Proposed Minnesota Constitutional Amendment. Disponível em: <http://www.house.leg.state.mn.us/hrd/pubs/recall96.pdf>. Acesso em: 17 jan. 2009.

${ }^{237}$ Id. Ibid.

${ }^{238}$ DALLARI, Dalmo de Abreu. Elementos de teoria geral do Estado, cit., p. 155.
} 
Como dito, a primeira espécie trata da revogação dos mandatos ou destituição de autoridades públicas mediante decisão popular. Nessa hipótese, um determinado número de eleitores, geralmente mediante depósito em dinheiro, requer uma consulta à opinião do eleitorado para decidir se será mantido ou revogado o mandato conferido a um agente público eleito. ${ }^{239}$ Cabe observar também que há nos Estados Unidos casos em que se permite a decisão popular para destituição de juízes, como acontece, por exemplo, no Estado de Minnesota. ${ }^{240}$

$\mathrm{Na}$ segunda espécie, ou seja, no recall judicial, os eleitores decidem se a decisão será anulada ou preservada. Anulada a decisão judicial por votação da maioria, a lei declarada inconstitucional volta a ser aplicada. Cabe frisar que o recall judicial não se refere à destituição de juízes e sim à revogação de decisões judiciais. A destituição de juízes refere-se à primeira espécie de recall, acima mencionada.

Tanto o recall de juízes como o recall judicial são bastante controvertidos. Desde quando foi instituído o recall, no início do Século XX, a possibilidade de destituir juízes e de revogar decisões judiciais sempre foi objeto de discussão, principalmente em razão do princípio da independência do Judiciário, princípio esse tão arraigado na sociedade americana como o princípio federativo.

Há argumentos contra e a favor do recall judicial. De um lado, há a alegação de que não se deve envolver o juiz no centro dos baixos interesses políticos, sob pena de suprimir-lhe a independência e a autoridade. De outro lado, há a alegação de que a lógica da democracia semidireta leva à adoção do recall, pois se o povo pode evitar as más leis por meio de referendo e obter boas leis por meio da iniciativa popular, os resultados desses procedimentos poderiam ser frustrados, caso não fosse permitida a revogação da decisão judicial que paralisasse ou negasse aplicação aos resultados dessas decisões políticas populares. ${ }^{241}$

Há também notícias de que já foi utilizada a primeira espécie de recall para destituição de diretores escolares e funcionários nomeados. ${ }^{242}$

\footnotetext{
${ }^{239}$ Há casos de recall de funcionários nomeados. Na maioria dos casos de recall ocorre também a escolha do substituto do agente público acusado.

${ }^{240}$ MINNESOTA House of Representatives. Disponível em: $<$ http://www.house.leg.state.mn.us/cco/rules/mncon.htm>. Acesso em: 17 jan. 2009.

${ }^{241}$ BONAVIDES, Paulo. op. cit., p. 293.

${ }^{242}$ No caso de diretores escolares, em princípio, não são considerados autoridades públicas e tais casos ocorrem em nível local. Quanto aos funcionários nomeados, obviamente não ocupam o cargo em decorrência de eleição, por isso, não deveriam ser submetidos ao recall. Mas, como se sabe, a democracia norte-americana possui esses detalhes, principalmente em decorrência da autonomia política dos Estadosmembros da Federação.
} 
Em que pese a existência de previsões normativas sobre o recall, seus resultados em nível estadual não são significativos, sendo que os dois únicos casos de revogação de mandato de governador ocorreram nos Estados de Dakota do Norte ${ }^{243}$ no ano de 1921 e no Estado da Califórnia no ano de 2003. ${ }^{244}$ O mecanismo é mais apropriado para questões locais.

\subsubsection{O recall nos Estados-membros americanos: hipóteses e procedimentos}

Como visto, atualmente, o recall é aplicável em dezoito estados norte$\operatorname{americanos}^{245}$. Dentre esses Estados, apenas sete prevêem em seus textos constitucionais e legais as descrições fáticas normativas (tipo legal) que dão ensejo ao procedimento de recall. São eles: Alaska, Georgia, Kansas, Minnesota, Montana, Rhode Island e Washington.

$\mathrm{O}$ art. XI, $\S 8^{\circ}$, item 8 , da Constituição do estado do Alaska $^{246}$ prevê o instituto do recall e o dispositivo que o complementa estipula como hipóteses para o procedimento a ausência de saúde física e mental, incompetência administrativa, negligência na execução das obrigações e corrupção. ${ }^{247}$

A Constituição do Estado da Georgia ${ }^{248}$, em seu art.II, seção II, $\S 4^{\circ}$, prevê o instituto do recall e $\S 21-4-3(7)$ e $§ 21-4-4$ do Georgia's Code ${ }^{249}$ estipulam as hipóteses que ensejam o procedimento, a exemplo do mau comportamento durante o exercício da função ou cargo; perjúrio; erro, negligência ou má-fé na execução das obrigações prescritas em lei; e desvio doloso de recursos públicos ou propriedades públicas.

\footnotetext{
${ }^{243}$ Nesse caso, os eleitores revogaram o mandato do governador Lynn J. Frazier, bem como do Procurador Geral e do Secretário de Agricultura ( $C f$. RECALL of State Officials. National Conference of State Legislatures - The Forum for America's Ideas, cit.).

${ }^{244} \mathrm{Na}$ Califórnia, desde 1911 ocorreram 32 procedimentos de recall para revogação de mandato de governador, sendo que o único caso de revogação foi o ocorrido em 2003 com o governador Gray Davis (Cf. RECALL of State Officials. National Conference of State Legislatures - The Forum for America's Ideas, cit.).

${ }^{245} \mathrm{Cf}$. Id. Ibid.

${ }^{246}$ THE CONSTITUTION OF THE STATE OF ALASKA. Disponível em: $<$ http://www.alaska.edu/creatingalaska/constitution>. Acesso em: 28 jan. 2008.

${ }^{247}$ Alaska Statute $\S 15.45 .510$. ALASKA Statute. Title 15. Elections. Disponível em: $<$ http://touchngo.com/lglcntr/akstats/Statutes/Title15.htm>. Acesso em: 18 dez. 2008.

${ }^{248} \mathrm{Cf}$. CONSTITUTION OF THE STATE OF GEORGIA. Disponível em: $<$ http://sos.georgia.gov/ELECTIONS/constitution_2007.pdf>. Acesso em: 18 dez. 2008.

${ }^{249} \mathrm{Cf}$. GEORGIA Law. Disponível em: <http://law.jstia.com/georgia/codes/21/21-4-3htm/>. Acesso em: 18 dez. 2008.
} 
$\mathrm{O}$ art. $4^{\circ}$, item 3 da Constituição do Estado de Kansas prevê o recall para todos os agentes públicos, com exceção dos juízes, e o art. 25, item 4302 do Kansas Statute 250 estabelece como hipóteses para a instauração do recall a condenação criminal por crime doloso; mau comportamento durante o exercício do cargo, incompetência administrativa e negligência na execução das obrigações previstas em lei.

$\mathrm{O}$ art. $8^{\circ}$, item 6 da Constituição de Minnesota ${ }^{251}$ prevê, por exemplo, a inexecução das obrigações decorrentes do cargo durante seu exercício e condenação criminal durante o exercício do cargo por crimes graves, e as hipóteses que ensejam o recall de juízes devem ser previstas pela Suprema Corte do Estado.

O Código do Estado de Montana ${ }^{252}$, em seu art. $2^{\circ}, \S 16$, item 603, estipula as hipóteses de ausência de saúde física ou mental, incompetência administrativa, perjúrio, mau comportamento durante o exercício do cargo e condenação criminal por prática de crime doloso, podendo ser submetido ao procedimento de recall qualquer funcionário público estadual, eleito ou indicado, de qualquer subsdistrito.

O Art. $4^{\circ}, \S 1^{\circ}$ da Constituição de Rhode Island ${ }^{253}$ permite o recall quando o governador, vice-governador, secretário de Estado, secretário do tesouro-finanças públicas ou o advogado-geral tiverem sido indiciados ou processados por crime doloso, condenados por contravenção ou crimes leves.

Por fim, o art. $1^{\mathrm{o}}, \S 33$ da Constituição do Estado de Washington ${ }^{254}$ prevê as hipóteses de prática de infrações e delitos, bem como incompetência administrativa e perjúrio durante o exercício do cargo ou função pública.

O recall de juízes não é permitido nos Estados do Alaska, Idaho, Kansas, Lousiana, Michigan e Washington. ${ }^{255}$

\footnotetext{
${ }^{250} \mathrm{Cf}$. KANSAS Legislature. Disponível em: <http://www.kslegislature.org/legsrvstatutes/getStatuteFile.do?number=/25-4302.html>. Acesso em: 18 dez. 2008.

${ }^{251}$ Cf. MINNESOTA CONSTITUTION. Article VIII. Impeachment and Removal from Office. Disponível em: <http://www.house.leg.state.mn.us/cco/rules/mncon/Article8.htm>. Acesso em: 18 dez. 2008.

${ }^{252}$ Cf. MONTANA CODE ANNOTATED - 2007. Disponível em: <http://data.opi.mt.gov/bills/mca/2/16/216-603.htm>. Acesso em: 18 dez. 2008.

${ }^{253}$ Cf. CONSTITUTION OF THE STATE OF RHODE ISLAND AND PROVIDENCE PLANTATIONS. Disponível em: <http://www.rilin.state.ri.us/RIConstitution/C04.html>. Acesso em: 18 dez. 2008.

${ }^{254} \mathrm{Cf}$ WASHINGTON $\quad$ STATE $\quad$ CONSTITUTION. $\quad$ Disponível em: $<$ http://www.leg.wa.gov/LawsAndAgencyRules/constitution.html>. Acesso em: 18 dez. 2008.

${ }^{255}$ RECALL of State Officials. National Conference of State Legislatures - The Forum for America's Ideas, cit.; RECALL of State Elected Officials. A Proposed Minnesota Constitutional Amendment. p. 6-9. Disponível em: <http://www.house.leg.state.mn.us/hrd/pubs/recall96.pdf>. Acesso em: 17 jan. 2009.
} 
Osvaldo Trigueiro, em meados do século passado, já registrava com breves palavras como funcionava o mecanismo do recall nos Estados Unidos da América do Norte, sendo que tal procedimento, em linhas gerais, continua basicamente o mesmo, com diferenças particulares de localidade para localidade.

Segundo este autor, o recall, assim como acontece com a iniciativa legislativa popular, pressupõe uma petição assinada por um determinado número de eleitores, autenticada, onde são apresentadas as razões que, em princípio, justificam o afastamento do agente público. ${ }^{256}$ Este, por sua vez, deve ser formalmente notificado sobre o pedido de instauração do procedimento de recall, havendo uma certa expectativa por parte dos proponentes de que o funcionário apresente sua renúncia nesse momento. Não havendo renúncia, geralmente, marca-se uma eleição, dentro de prazo fixado na respectiva lei. ${ }^{257}$

Após a fase de petição, a eleição de recall pode ocorrer de duas formas. ${ }^{258}$

Na primeira, há uma única eleição na qual já se decide sobre a substituição da autoridade acusada. Esta primeira forma, por sua vez, possui duas variantes. Na primeira variante, procede-se apenas a uma eleição para o cargo, concorrendo o acusado como candidato. Nesse caso, portanto, consta da cédula de votação o nome do candidato, podendo este ser reeleito ou destituído. ${ }^{259} \mathrm{Na}$ segunda variante ${ }^{260}$, o eleitor vota, em primeiro lugar, sobre a destituição ou não da autoridade acusada e, depois, sobre quem deverá substituí-la. Nessa hipótese, ambos os votos são expressos na mesma cédula e a autoridade acusada não poderá concorrer como candidato. ${ }^{261}$

\footnotetext{
${ }^{256} \mathrm{O}$ número de assinaturas para que a petição de recall seja considerada apta é mais elevado que o número previsto para a iniciativa popular. Os requerimentos com as assinaturas são baseados, geralmente, em um percentual dos votos da última eleição daquele que está sendo submetido ao procedimento. Há Estados que não adotam fórmula específica, preferindo estabelecer o número de assinaturas com base no número de eleitores inscritos na respectiva circunscrição eleitoral. RECALL of State Officials. National Conference of State Legislatures - The Forum for America's Ideas, cit.

${ }^{257}$ TRIGUEIRO, Osvaldo. op. cit., p. 149.

${ }^{258}$ RECALL of State Officials. National Conference of State Legislatures - The Forum for America's Ideas, cit. Cf. tb TRIGUEIRO, Osvaldo. op. cit., p. 149.

${ }^{259}$ Arizona, Nevada, North Dakota e Wisconsin. RECALL of State Officials. National Conference of State Legislatures - The Forum for America's Ideas, cit.

${ }^{260}$ California e Colorado. RECALL of State Officials. National Conference of State Legislatures - The Forum for America's Ideas, cit.

${ }^{261}$ Quando do recall do governador Gray Davis na Califórnia, no ano de 2003, quatro eleitores juntamente com uma associação denominada "California Informed Voters Group" ajuizaram uma ação judicial em face do Secretário de Estado da Califórnia e outros agentes públicos, alegando que o art. 11382 do Código Eleitoral do Estado (que determina que nenhum voto será contabilizado ao candidato sem que o eleitor vote antes contra ou a favor da destituição do agente público) violava os seus direitos constitucionais previstos na $9^{\mathrm{a}}, 14^{\mathrm{a}}, 15^{\mathrm{a}}, 19^{\mathrm{a}}$ e $26^{\mathrm{a}}$ emendas constitucionais. Votar contra ou a favor do governador Gray Davis a título de pré-requisito de validade do segundo voto (que decidiria quem deveria substituir o governador submetido ao procedimento de recall) seria inconstitucional na visão dos autores da ação porque haveria
} 
$\mathrm{Na}$ segunda forma, a cédula de votação contém apenas a pergunta se a autoridade acusada deve ser destituída ou não do cargo. Se a maioria decidir pela destituição, o cargo é declarado vago e uma nova eleição deverá ser realizada para que os eleitores escolham o substituto. ${ }^{262}$

\subsubsection{Os resultados gerais do recall}

Thomas E. Cronin ${ }^{263}$ traça um panorama geral sobre os casos de recall nos Estados Unidos da América do Norte. Ele registra que o dispositivo é pouco utilizado para destituição de juízes e promotores (e outras autoridades eleitas) e sua utilização contra governadores são raríssimas. ${ }^{264}$ Em contrapartida, o mesmo não ocorreu com os legisladores estaduais, que já tiveram seus mandatos revogados, incluindo dois deputados da Califórnia em 1913, dois em Idaho em 1971, dois em Michigan em 1983 e um em Oregon em 1988. No Arizona, no ano de 1987, a campanha pela revogação do mandato do governador Evan Mechan obteve um elevado número de assinaturas, aproximadamente 216.000, muito além do que é exigido pela legislação, fato esse que levou a uma investigação rigorosa por parte da respectiva assembleia legislativa, resultando no seu impeachment. O comitê que organizou o recall de Mechan alegava que ele não possuía o conhecimento, a visão e a liderança unificadora necessárias para ser um bom governador, bem como que ele representava uma vergonha para os cidadãos do Arizona perante o país, em razão de suas declarações insensatas sobre as mulheres e as minorias.

Cronin $^{265}$ registra também que aproximadamente 2.000 autoridades municipais e de condados foram destituídas de seus cargos e funções nos Estados Unidos desde a

ofensa ao livre exercício do voto. A ação foi julgada procedente em 29/07/2003, sendo acatados os argumentos da inicial, com a declaração de inconstitucionalidade do art. 11832 do Código Eleitoral do Estado da Califórnia, garantindo aos autores de forma permanente o direito de não votar no quesito específico da cédula referente ao recall, cabendo aos eleitores apenas decidir sobre quem deveria substituir o agente objeto de recall, devendo ser considerados válidos os votos dos autores assim expressos. (cf. FINLAW. Disponível em: $<$ http://fl1.findlaw.com/news.findlaw.com/hdocs/docs/electionspartnoyshlly072903opn.pdf>. Acesso em: 16 dez. 2008.)

${ }^{262}$ Casos de duas eleições distintas estão previstos nos Estados da Georgia, Lousiana, Michigan, Minnesota, Montana, Nova Jersey, Oregon e Rhode Island. Nos Estados de Idaho, Alaska e Kansas, a eleição de recall trata apenas da destituição da autoridade. Havendo a remoção por decisão popular, na sequencia, ocorre a indicação e a nomeação de um substituto para cumprimento do tempo restante do mandato. RECALL of State Officials. National Conference of State Legislatures - The Forum for America's Ideas, cit.

${ }^{263}$ CRONIN, Thomas E. op. cit., p. 127.

${ }^{264} \mathrm{O}$ caso mais conhecido, hoje, é o do governador Gray Davis, que foi substituído pelo ator de Hollywood Arnold Schwazenerger no ano de 2003, na Califórnia.

${ }^{265}$ CRONIN, Thomas E. op. cit., p. 128. 
instauração do recall em Los Angeles no ano de 1903. Prefeitos de muitas cidades, de Seattle a Atlantic City, foram submetidos ao procedimento de recall. No ano de 1978, o prefeito de Cleveland sofreu um procedimento de recall, mas seu mandato não foi revogado pelo voto popular. Em 1983, o prefeito de São Francisco também foi submetido ao recall, sendo mantido ao final no cargo. Em 1987, o prefeito de Omaha teve seu mandato revogado, com altíssimo comparecimento de eleitores às urnas. Em 1979, o diretor de uma escola de Los Angeles foi submetido ao mecanismo e, em 1985, três vereadores da cidade de Honolulu foram destituídos pela votação popular. Em 1978, na cidade de Easton, no estado de Massachusetts, toda a diretoria de uma escola foi destituída por meio de recall. Em 1986, seis vereadores de Grand Junction, no estado de Colorado, foram destituídos. E, em 1987, a população de Nebraska votou contra 36 autoridades eleitas em 25 procedimentos distintos de recall, que resultou na destituição de 16 pessoas de seus cargos.

\subsubsection{O caso Gray Davis}

O recall californiano encontra-se previsto no artigo II, parágrafo 13 da Constituição Estadual $^{266}$ e na seção 11 do Código Eleitoral da Califórnia. ${ }^{267}$

O dispositivo constitucional do Estado da Califórnia data de 1911 e o código eleitoral, no que se refere ao recall, possui ampla regulação com mais de sessenta artigos.

Joseph Graham “Gray” Davis Jr., do Partido Democrata, assumiu o poder em 1999 e foi destituído por meio de votação popular em 7 de outubro de $2003 .^{268}$

O movimento para revogação do mandato do governador californiano se iniciou por meio de defensor público do Estado e por um grupo de ativistas do Partido Republicano. Inicialmente parecia que o recall não iria para frente, porém, em maio de 2003, um deputado de San Diego conseguiu substanciais recursos financeiros e organizacionais, incluindo um website que se tornou muito popular e que deu o empurrão

\footnotetext{
${ }^{266}$ California Constitution, article II, Section 13: "Recall is the Power of the electors to remove and elective officer". OFFICIAL California Legislative Information. Disponível em: <http://www.leginfo.ca.gov/cgibin/waisgate>. Acesso em: 22 dez. 2008.

${ }^{267}$ CALIFORNIA Law. Disponível em: <http://www.leginfo.ca.gov/cgibin/calawquery?codesection=\&elec \&codebody=hits=20>. Acesso em: $22 \mathrm{dez} .2008$.

${ }^{268} \mathrm{UC} \quad$ BERKELY. Institute of Governamental Studies. Disponível em: <http://igs.berkeley.edu/library/htrecall2003.html>. Acesso em: 22 dez. 2008.
} 
que faltava para a instauração do procedimento para revogação do mandato do governador Gray Davis.

O mínimo de assinaturas exigido de acordo com a lei do Estado da Califórnia, na época, era de 897.156, mas acreditava-se que, para garantir o número necessário de assinaturas válidas para dar início ao mecanismo, seria necessário pelo menos 1.200.000 assinaturas no total. Em 23 de julho de 2003 foi alcançado o número de 1.356.408 assinaturas válidas e, dessa forma, não restou outra alternativa ao Secretário de Estado senão atestar que foram preenchidos os requisitos legais para o recall.

O vice-governador do Estado, Cruz Bustamante, então, determinou a eleição de recall para o dia 7 de outubro de 2003. Nesta eleição, houve um grande número de candidatos $^{269}$, concorrendo inclusive o vice-governador e o republicano, ator de Hollywood, Arnold Schwarzenegger.

Muitas ações judiciais foram ajuizadas pelos cidadãos, principalmente para discutir direitos constitucionais dos eleitores, No entanto, nenhuma delas atrasou o andamento do procedimento e a votação marcada para o dia 7 de outubro.

Com cento e trinta e cinco candidatos à eleição, os eleitores tiveram um grande trabalho na hora da votação individual, pois precisaram procurar o nome de seu candidato numa extensa cédula eleitoral.

Gray Davis foi destituído e em seu lugar foi eleito Schwarzenegger com mais de $48 \%$ (quarenta e oito por cento) dos votos válidos.

$\mathrm{Na}$ Califórnia, nessa época, durante os meses que antecederam a eleição, os opositores do procedimento sustentavam que o recall era um mecanismo não-democrático porque o eventual vencedor da eleição poderia receber menos votos do que havia recebido Davis na sua eleição passada ou, ainda, menos votos do que Davis iria receber para sua exoneração. Todavia, esse argumento caiu por terra, quando Schwarzenegger recebeu votação mais expressiva que aquela que Davis havia recebido, tanto anteriormente como na votação pela sua remoção. ${ }^{270}$

\footnotetext{
${ }^{269}$ Cento e trinta e cinco candidatos, no total.

${ }^{270}$ SPIVAK, Joshua. op. cit., p. 33.
} 


\subsection{Instrumentos semelhantes ao recall em outros sistemas jurídicos}

\subsubsection{Canadá - British Columbia}

Brithish Columbia é a única província do Canadá que admite o recall e o procedimento é permitido apenas para remover membros do Poder Legislativo. ${ }^{271}$

Qualquer eleitor pode solicitar à autoridade superior eleitoral a instauração de um procedimento de recall. Se a solicitação preencher certos requisitos (assinatura, motivação da solicitação com as razões para instauração do procedimento e depósito em dinheiro), a autoridade eleitoral expedirá uma notificação às partes envolvidas e emitirá uma petição de recall em nome do solicitante. Este, por sua vez, terá sessenta dias para coletar assinaturas (no número equivalente a $40 \%$ dos eleitores que estiverem inscritos no distrito eleitoral). Conferidas as assinaturas, após verificação da presença de todos os requisitos prévios, marca-se a data para a eleição de recall. ${ }^{272}$

O caso mais conhecido de recall na Província de Columbia foi a tentativa de recall do deputado Paul Reitsma, ocorrida no ano de 1998, que resultou na renúncia do cargo pelo referido deputado antes da declaração da vacância do cargo. ${ }^{273}$

\subsubsection{América Latina}

$\mathrm{O}$ art. 72 da Constituição venezuelana ${ }^{274}$ prevê instituto semelhante ao recall com a denominação de referendo revocatório.

De acordo com este dispositivo constitucional, todos os cargos decorrentes de eleição popular são passíveis de revogação.

O pedido de referendo revocatório só poderá ser realizado depois de transcorrida a metade do período do mandato político e o requerimento deverá ser subscrito por pelo menos vinte por cento dos eleitores inscritos na correspondente circunscrição eleitoral onde foi eleito o mandatário. O mandato será revogado por maioria

\footnotetext{
${ }^{271}$ A legislação de British Columbia se utiliza do termo recall (em inglês) para designar o procedimento para destituição de autoridades públicas.

${ }^{272}$ BRITISH COLUMBIA LAWS. Disponível em: <www.bclaws.ca/Recon/document/ID/freeside/96398_02>. Acesso em: 25 jan. 2009.

${ }^{273}$ CBC.ca. Disponível em: <http://www.cbc.ca/news/story/1998/06/23/reistma980623a.html>. Acesso em: 13 jan. 2009.

${ }^{274}$ CONSTITUCIÓN DE LA REPÚBLICA BOLIVARIANA DE VENEZUELA. Disponível em: <http://www.analitica.com/BITBLIO/anc/constitucion1999.asp>. Acesso em: 18 dez. 2008.
} 
simples, desde que tenha participado pelo menos vinte e cinco por cento dos eleitores inscritos.

A Constituição do Peru ${ }^{275}$, em seu art. 31, prevê que os cidadãos têm direito de participar dos assuntos públicos mediante referendo, iniciativa legislativa, remoção ou renovação de autoridades e pedidos de prestação de contas.

A Constituição da Colômbia ${ }^{276}$, por seu turno, estipula em seu art. 40, que todo cidadão tem o direito de participar da formação, exercício e controle do poder político, efetivando esses direitos ao tomar parte das eleições, plebiscitos, referendos e consultas populares, sendo-lhe permitido, ainda, dentre outros direitos, revogar o mandato dos eleitos de acordo com a Constituição e a respectiva lei complementar.

Esse dispositivo constitucional colombiano foi regulado, por seu turno, pela Lei $\mathrm{n}^{\mathrm{o}} 131$, de 1998 , modificada pela Lei $\mathrm{n}^{\mathrm{o}} 741^{277}$, de 2002 , que, em seu art. $7^{\circ}$, item 4 , estabeleceu que o procedimento de revogação do mandato somente poderá ocorrer depois de um ano, contado a partir da posse do prefeito ou governador, devendo o requerimento fundamentado com os motivos do procedimento conter no mínimo $40 \%$ (quarenta por cento) do total dos votos que foram obtidos pelo agente público. Os eleitores da respectiva circunscrição eleitoral serão convocados para se pronunciarem sobre a revogação do mandato dentro de um período de até dois meses contados da confirmação e aceitação oficial do requerimento. $\mathrm{O}$ mandato do prefeito ou governador será revogado se houver aprovação da metade mais um dos votos dos eleitores que participarem do procedimento.

$\mathrm{Na}$ Argentina, a revogação de mandato não está prevista em nível nacional, mas em nível estadual (lá chamado de provincial). O instituto está previsto na Constituição da Província de Córdoba, em seu art. 183, item $4{ }^{278}$

\footnotetext{
${ }^{275}$ CONSTITUCIÓN POLÍTICA DEL PERÚ. Disponível em: $<$ http://www.tc.gob.pe/legconperu/constitucion.html>. Acesso em: 18 dez. 2008.

${ }^{276}$ REPUBLICA DEL COLÔMBIA. Secretaria del Senado. Disponível em: <http://www.secretariasenado.gov.co/leyes/CONS_P91.htm>. Acesso em: 18 dez. 2008.

${ }^{277} \mathrm{LEY} \quad$ n. 741 de 2002 (COLOMBIA). Disponível em: $<$ http://www.secretariasenado.gov.co/senado/basedoc/ley/2002/ley_0741_2002.html>. Acesso em: 25 jan. 2009.

${ }^{278}$ Constitucion de La Provincia de Córdoba y su Reforma Sancionada com fecha 14 de septiembre de 2001. Artículo 183. Las Cartas Orgànicas deben asegurar: (...) 4. Los derechos de iniciativa, referendum y revocatória. SECRETARIA DE AMBIENTE Y DESAROLLO SUSTENTABLE DE LA NACIÓN. Disponível $<$ http://www.ambiente.gov.ar/archivos/web/biblioteca/File/Constituciones/cp_cordoba.pdf $>$. Acesso em: 18 dez. 2008.
} 
A Bolívia aprovou, em 12 de maio de 2008, a Lei $\mathrm{n}^{\mathrm{o}} 3850^{279}$, instituindo a figura do referendo revogatório que permitiu a revogação ou continuidade da gestão do Presidente da República e do Vice-Presidente, em nível nacional, e dos governadores (prefectos de departamento), em nível regional.

O artigo 84 da Constituição de $\mathrm{Cuba}^{280}$ prevê que os deputados da assembleia nacional do poder popular têm o dever de desenvolver suas atividades em benefício do interesse popular, manter contato com seus eleitores, ouvindo suas dúvidas, sugestões e críticas, bem como o dever de explicar ao povo a política do Estado e, da mesma forma, prestar contas acerca do cumprimento de suas funções, de acordo com o estabelecido em lei, e o art. 85 estabelece que tais deputados poderão ter seus mandatos revogados a qualquer momento, segundo lei específica.

Auro Augusto Caliman ${ }^{281}$ observa que, em 14 de setembro de 1999 sobreveio a lei cubana regulando o art. 85 da Constituição desse país, a qual estabeleceu que podem ser revogados os mandatos dos deputados da Assembleia Nacional, delegados das Assembleias Municipais e Provinciais, bem como de outros órgãos representativos do poder popular, sendo cabível a revogação do mandato parlamentar quando houver descumprimento reiterado das obrigações derivadas do mandato, o parlamentar incorrer em fato que afete sua reputação pública ou praticar conduta incompatível com a honra de representar o povo em órgão de Poder Popular. Diz também a lei que a iniciativa para promoção do procedimento de revogação do mandato popular cabe ao Conselho de Estado, a qualquer deputado, a um quarto, no mínimo, dos delegados da Assembleia do Município por onde foi eleito o deputado submetido ao procedimento de revogação popular. Por fim, cabe esclarecer que a revogação do mandato dar-se-á não por votação popular, mas sim pela maioria dos votos dos membros da casa legislativa.

\subsubsection{Europa}

Instituto similar ao recall também pode ser encontrado na República de Belarus ou Bielo-Rússia localizada no centro-nordeste da Europa. A Constituição deste

\footnotetext{
${ }^{279}$ REPUBLICA DE BOLIVIA. Corte Nacional Electoral. Disponível em: $<$ http://www.cne.org.bo/prces_electoral/Revocatorio2008/documentos/leyconvocatoria.pdf $>$. Acesso em: 19 dez. 2008.

${ }^{280}$ CONSTITUCIÓN DE LA REPUBLICA DE CUBA. Disponível em: <http://www.cuba.cu/gobierno/cuba.htm>. Acesso em: 26 dez. 2008.

${ }^{281}$ CALIMAN, Auro Augusto. Mandato parlamentar: aquisição e perda antecipada. São Paulo: Atlas, 2005. p. 112.
} 
país, em seu art. $72^{282}$, determina que será permitida a destituição de deputados desde que haja concordância de, pelo menos, $20 \%$ (vinte por cento) do eleitorado da respectiva circunscrição eleitoral, sendo que os motivos e pedidos para a revogação serão regulamentados em lei.

\subsubsection{Etiópia}

$\mathrm{O}$ art. 12 da Constituição da Etiópia estabelece que o povo pode remover qualquer um de seus representantes sempre que houver perda de confiança popular. E o mesmo artigo estatui que os membros do Poder Legislativo deverão prestar contas permanentemente ao povo da Etiópia. ${ }^{283}$

\subsection{5. Ásia}

Na China não existe o recall democrático, por votação dos eleitores. No entanto, o art. 63 da Constituição chinesa ${ }^{284}$ permite que o Congresso Nacional Popular proceda a revogação do mandato do Presidente e do Vice-presidente da República Popular da China, ministros, militares, do Presidente da Suprema Corte Judicial e do Procurador Geral da República chinesa. Evidentemente, não se trata aqui do instituto recall, objeto desta tese de doutorado.

A Constituição do Japão ${ }^{285}$, em seu art. 78, dispõe que os juízes não deverão ser removidos de seus cargos, exceto no caso de impeachment popular, declaração judicial de incapacidade física ou mental para executar seus deveres oficiais e, em seu art. 79, estipula que a nomeação dos juízes da Suprema Corte será revista pelo povo na primeira eleição geral dos membros da Câmara dos Representantes que se seguir à sua nomeação e será revista novamente na primeira eleição geral de membros da Câmara de Representantes

\footnotetext{
${ }^{282}$ BELARUS CONSTITUTION. Disponível em: <http://www.president.gov.by/en/press 10669.html>. Acesso em: 25 jan. 2009.

${ }^{283}$ ETHIOPIAN CONSTITUTION Disponível em: $<$ http://www.sas.upenn.edu/African_Studies/Hornet/Ethiopian_Constitution.html>. Acesso em: 25 jan. 2009.

${ }^{284}$ CONSTITUTION OF THE PEOPLE'S REPUBLIC OF CHINA. Disponível em: <http://www.usconstitution.net/china.html\#Article63>. Acesso em: 16 jan. 2009.

${ }^{285}$ CONSTITUTION OF JAPAN. Disponível em: <http://www.solon.org.Constitutions/Japan/English/english-Constitution.html>. Acesso em: 25 jan. 2009.
} 
após um lapso de dez anos e, da mesma forma, assim por diante, e quando a maioria dos eleitores for favorável à destituição de um juiz, este será demitido. ${ }^{286}$

\footnotetext{
${ }^{286}$ Sobre a destituição dos juízes no Japão, Monica Herman Salem Caggiano explica que "o mecanismo, na verdade, funciona mais como uma aceitação, na medida em que os juízes não são eleitos, mas nomeados pelo gabinete, e não se aplica em relação ao juiz presidente" (CAGGIANO, Monica Herman Salem. Oposição na política: propostas para uma rearquitetura da democracia, cit., p. 98).
} 


\section{O RECALL E O SISTEMA JURÍDICO BRASILEIRO}

\subsection{A revogação do mandato político no direito brasileiro}

\subsubsection{Século XIX}

O primeiro esboço que se tem notícia, no Brasil, sobre a revogação dos mandatos dos representantes políticos remonta ao processo eleitoral para as províncias do Império. O decreto datado de 16 de fevereiro de 1822, criado pelo príncipe regente, para as eleições do Conselho de Procuradores do Estado, previa a possibilidade de perda do mandato do procurador, por meio de eleição, caso este não desempenhasse corretamente suas obrigações. $^{287}$

No Brasil, a revogação do mandato político nunca foi permitida pela Constituição Federal. No entanto, no final do Século XIX, a revogação foi instituída nas Constituições dos Estados de Goiás, São Paulo, Rio Grande do Sul e Santa Catarina ${ }^{288}$.

A Constituição do Estado de Goiás, promulgada em $1^{\circ}$ de junho de 1.891, em seu art. 56 dispunha que "O mandato legislativo não será obrigatório e o eleitorado poderá cassá-lo, declarando mediante o processo que a lei estabelecer, o mandatário carecedor de sua confiança".

$\mathrm{O}$ art. $6^{\circ}, \S 3^{\circ}$ da Constituição do Estado de São Paulo, promulgada em 14 de julho de 1891, previa que os deputados e senadores estaduais poderiam ter seus mandatos cassados a qualquer tempo, mediante consulta feita ao eleitorado por proposta de um terço dos eleitores.

Por sua vez, a Constituição do Rio Grande do Sul, promulgada na mesma data da Constituição Paulista, em seu art. 39 estabelecia que "O mandato do representante não será obrigatório; poderá ser renunciado em qualquer tempo e também cassado pela maioria dos eleitores".

Por fim, a Constituição do Estado de Santa Catarina, de 7 de julho de 1892, previa, em seu art. 14, que "O mandato legislativo pode ser renunciado, e sua

\footnotetext{
${ }^{287}$ BENEVIDES, Maria Victoria de Mesquita. A cidadania ativa: referendo, plebiscito e iniciativa popular. São Paulo: Ática, 2000, p. 112.

${ }^{288}$ CALIMAN, Auro Augusto. O recall no Estado de São Paulo. Revista de Informação Legislativa, Brasília, v. 42, n. 165, p.197-203, jan./mar. 2005.
} 
revocabilidade se efetuará quando, consultado o eleitorado por um terço dos eleitores, não obtiver o deputado metade e mais um dos votos com que foi eleito".

Os dispositivos das Constituições de São Paulo e do Rio Grande do Sul foram posteriormente regulados pelas legislações estaduais. ${ }^{289}$

Não há notícias de que tenha ocorrido revogação de mandatos nesses Estados brasileiros. $^{290}$

\subsubsection{A revogação de mandato e a Constituição Federal}

\subsubsection{O voto destituinte}

Segundo Michel Temer ${ }^{291}$, durante a Assembléia Constituinte foi apresentada uma proposta de emenda com o chamado voto destituinte, permitindo aos eleitores $(0,5 \%$ do eleitorado de cada Município, Estado ou da União) encaminhar petição fundamentada às Mesas das Casas Legislativas, solicitando a destituição do parlamentar.

O mesmo autor afirma que recall e voto destituinte são institutos distintos. No recall dos Estados Unidos, se a autoridade pública abusar de seus misteres e deveres, a maioria dos eleitores pode agir diretamente e destituí-lo. Com o voto destituinte, procurase tornar viável a iniciativa popular, via preceito constitucional, com o encaminhamento das petições ao Poder Legislativo que deflagrará ou não o procedimento de responsabilização política da autoridade pública. ${ }^{292}$

De fato, recall e voto destituinte não são o mesmo instituto. No recall norteamericano não há participação do Legislativo no procedimento. Além disso, o instrumento ianque decorre de uma ideia concreta relacionada ao "Good Business Principle", na qual pretende-se que administração pública das cidades (principalmente) seja levada a efeito por bons profissionais, tanto do ponto de vista ético como técnico. O instituto denominado recall é um mecanismo existente nos Estados Unidos, principalmente em nível local (não

\footnotetext{
${ }^{289}$ No Estado de São Paulo pela Lei $\mathrm{n}^{\circ} 21$, de 27 de novembro de 1891 e decreto $\mathrm{n}^{\circ} 20$, de 6 de fevereiro de 1892 e no Estado do Rio Grande do Sul pela Lei n ${ }^{\circ}$, de 12 de janeiro de 1897.

${ }^{290}$ Sobretudo, as razões principais para a não-utilização do instituto foram as dificuldades no recolhimento de assinatura dos eleitores e o coronelismo existente à época na esfera política. (cf. CALIMAN, Auro Augusto. O recall no Estado de São Paulo, cit., p. 201).

${ }^{291}$ TEMER, Michel. Democracia e cidadania. São Paulo: Malheiros Ed., 2006. p. 73.

${ }^{292}$ Id. Ibid., p. 73.
} 
há previsão em nível nacional), que necessita de um elevado número de assinaturas para sua instauração e em muitos casos depende de caução prévia em dinheiro. Foi largamente utilizado nos Estados Unidos, mas obteve, na prática, em nível estadual, poucos resultados de revogação, servindo como um instrumento de controle do poder político, só pelo fato de existir, tratando-se de uma arma democrática do cidadão norte-americano, uma lembrança permanente que deve existir na memória das autoridades públicas. Além disso, o recall, nos Estados Unidos, serve também para revogar decisões judiciais e destituir juízes.

Calha, por fim, tecer breves considerações acerca da proposta de voto destituinte apresentada no ano de 1987, de autoria do deputado Lysâneas Maciel ${ }^{293}$, que, aparentemente, não é a mesma a que se refere Michel Temer. Tal proposta previa apenas que os detentores de mandatos eletivos teriam o dever de prestar contas de suas atividades e que os eleitores poderiam, por meio do voto, revogar o mandato concedido aos seus representantes no Congresso Nacional, nas Assembleias Legislativas e nas Câmaras Municipais, de acordo com lei complementar que seria editada para regramento do dispositivo constitucional.

Apesar das acaloradas discussões havidas à época, a ideia do voto destituinte não foi para frente e a Constituição Federal de 1988 trouxe em seu texto apenas as hipóteses do plebiscito, referendo e da iniciativa popular.

O voto destituinte não passou de uma ideia no papel, que não foi levada adiante, não existiu no mundo jurídico e não passou de um debate no Congresso Nacional.

\subsubsection{A Proposta de Emenda Constitucional $n^{0} 0073 / 2005$}

A Ordem dos Advogados do Brasil apresentou uma proposta de emenda constitucional ( $\mathrm{PEC} \mathrm{n}{ }^{\circ}$ 0073/2005) $)^{294}$ para acrescentar ao art. 14 da Constituição a possibilidade de revogação dos mandatos do Presidente da República, Deputados e Senadores.

O procedimento para revogação desses mandatos políticos previsto na proposta da Ordem dos Advogados do Brasil também difere do recall norte-americano.

\footnotetext{
${ }^{293}$ CÂMARA DOS DEPUTADOS. Assembléia Nacional Constituinte. Disponível em: <http://www.camara.gov.br/internet/constituicao20anos/DocumentosAvulsos/vol-74.pdf>. Acesso em: 13 jan. 2009. Cf. também AIETA, Vânia Siciliano. O recall e o voto destituinte. Revista de Direito Constitucional e Internacional, São Paulo, v. 10, n. 40, p. 164, jul./set. 2002.
${ }^{294}$ SENADO FEDERAL. Disponível em: $\quad<$ Disponível em: $<$ http://www.senado.gov.br/sf/publicacoes/diarios/pdf/sf/2005/12/09122005/43632.pdf>. Acesso em: 13 jan. 2009.


$\mathrm{O}$ art. $2^{\circ}$ da referida proposta de emenda constitucional estabelece, em resumo, que, transcorrido um ano da data da posse nos respectivos cargos, o Presidente da República, ou os membros do Congresso Nacional (deputados e senadores), poderão ter seus mandatos revogados por meio de referendo popular. Ainda neste dispositivo, há a previsão de que o referendo será realizado por iniciativa popular, dirigida ao Tribunal Superior Eleitoral e exercida mediante assinatura de dois por cento do eleitorado nacional, distribuído por, pelo menos, sete estados, com não menos do que cinco décimos por cento em cada um deles. Dispõe, também, que o eleitorado nacional poderá decidir a dissolução da Câmara dos Deputados, convocando-se nova eleição, que será realizada no prazo máximo de três meses. A proposta prevê que o referendo para revogação do mandato do Presidente da República poderá também ser realizado mediante requerimento da maioria absoluta dos membros do Congresso Nacional, dirigida ao Tribunal Superior Eleitoral. O referendo será considerado sem efeito se a soma dos votos nulos e em branco corresponder a mais da metade do total dos sufrágios expressos. Se o resultado do referendo for contrário à revogação do mandato eletivo, não poderá ser feita nova consulta popular sobre o mesmo assunto, até a expiração do mandato ou término da legislatura.

Percebe-se que a proposta do "recall brasileiro" buscou sua inspiração no recall norte-americano e no abberunfungrecht suíço, pois mescla os dois institutos e apresenta um resultado próprio.

Pela análise da referida proposta de emenda constitucional, verifica-se, inicialmente, que, para os cargos majoritários de Senador e Presidente da República, previu-se a iniciativa popular dirigida ao Tribunal Superior Eleitoral para convocação de referendo para revogação dos mandatos dessas autoridades públicas, sendo que, no caso do cargo de Presidente da República, a iniciativa para o referendo poderá também partir de requerimento assinado pela maioria absoluta dos membros do Congresso Nacional. Portanto, pela proposta ora discutida, a iniciativa para requerer a instauração do referendo para revogação do mandato presidencial poderá partir tanto do eleitorado como do Congresso Nacional. A iniciativa para requerer o referendo para revogação do mandato do Senador da República é reservada exclusivamente ao eleitorado, o mesmo sendo válido para a revogação dos mandatos dos membros da Câmara dos Deputados, afastada, nesse caso, qualquer hipótese de requerimento de referendo pelo Congresso Nacional.

Nos casos dos cargos de Senador e Presidente da República, que são obtidos pelo sistema majoritário, a votação popular mediante referendo decidirá se seus mandatos 
serão revogados ou não. Nas hipóteses de serem confirmados no cargo, não poderão mais ser realizadas outras consultas populares sobre o tema, até o término da legislatura ou mandato. Já nos casos dos deputados, que são eleitos pelo sistema proporcional, a decisão popular não será sobre o mandato individual de um representante específico, mas sobre todo o corpo legislativo, i.e., a decisão popular será no sentido de se manter ou não toda a Câmara dos Deputados e, no caso de revogação de todos os mandatos, o Tribunal Superior Eleitoral deverá convocar novas eleições para composição da nova Câmara dos Deputados, dentro de até três meses contados da dissolução.

Verifica-se, pois, que a revogação dos mandatos dos Senadores e do Presidente da República inspirou-se no recall norte-americano. Já no caso da revogação dos mandatos da Câmara dos Deputados, a inspiração obviamente vem do abberunfungsrecht suíço.

Enfim, a proposta da Ordem dos Advogados do Brasil não corresponde ao recall norte-americano.

\subsection{O panorama brasileiro}

A crise da representação política é um fenômeno mundial que vem sendo discutida desde o século XIX.

$\mathrm{Na}$ América Latina a crise é ainda mais visível e, no Brasil, o problema é gravíssimo e também se arrasta há longa data.

O problema é mais flagrante no Poder Legislativo, mas está presente também nas outras funções estatais. Os veículos de comunicação mostram diariamente que há senadores e deputados envolvidos em escândalos independente do partido a que estejam vinculados. Fala-se em ajuda financeira de lobistas para Deputados e Senadores, falsos dossiês, anões do orçamento, compra de votos para reeleição, quebra de sigilo do painel eletrônico do Senado, escândalos com bingos, correios, gastos com combustíveis, além de inúmeros outros escândalos de natureza criminal, todos de alguma forma vinculados a um representante que exerce mandato político, além de envolver, não raramente, também, membros do Executivo.

No Judiciário, que, também, de certa forma, possui caráter representativo, há escândalos angustiantes, a exemplo das vendas de sentenças e envolvimento de juízes em outros atos de corrupção. 
Muitos alegam que o sistema é assim mesmo. Os veículos de comunicação apenas mostram o que já existia há tempos, havendo formas de controle para corrigir essas falhas. Mas será que os sistemas de controle funcionam? O sistema interno, dentro das corporações, praticamente não funciona, exceto quando há interesses políticos envolvidos. O sistema de controle "entre poderes" às vezes funciona às vezes não, tudo depende também de questões políticas. O controle externo, quando existe, tende a funcionar melhor, mas da mesma forma está sujeito a todo tipo de influência.

Tudo isso produz um sentimento generalizado no eleitorado de que não existe representação e que dificilmente essa situação será corrigida de forma racional e objetiva.

Esses são os problemas sensíveis, imediatos, havendo outros mais técnicos que dizem respeito a outros aspectos, que envolvem o Direito, as Ciências Sociais e até a própria história e cultura brasileira.

\subsubsection{A representação política no Brasil}

Monica Herman Salem Caggiano ${ }^{295}$ observa que as primeiras experiências representativas no Brasil ${ }^{296}$ surgiram no complexo da organização municipal, sob a égide das Ordenações Alfonsinas e Manuelinas, as quais previam eleição de vereadores para as Câmaras locais.

Posteriormente, a Carta Imperial de 1824 assumiu uma nítida orientação favorável ao mandato livre ${ }^{297}$, conforme se depreende da leitura dos seus arts. 11 e $12 .^{298}$

Sobre os períodos posteriores à Constituição de 1824, ensina a ilustre Professora Caggiano como se desenvolveu a representação no País:

Fiel à tradição, o constituinte brasileiro tem mantido a praxe das amplas linhas do governo representativo, seguindo o modelo segundo o qual o poder emana do povo e em seu nome é exercido, com irrefutável inclinação à doutrina da soberania nacional, desvinculando o eleito de qualquer instrução impositiva por parte dos eleitores. A vontade parlamentar, nesse contexto, configura a vontade da nação (ou do povo), consubstanciando-se em tarefa precípua dos congressistas atender aos

\footnotetext{
${ }^{295}$ CAGGIANO, Monica Herman Salem. Sistemas eleitorais x representação política, cit., p. 33.

${ }^{296}$ Durante o período colonial.

${ }^{297}$ CAGGIANO, Monica Herman Salem. Sistemas eleitorais x representação política, cit., p. 33.

${ }^{298}$ Constituição Imperial de 1824. "Título $3^{\circ}$. Dos poderes, e representação nacional. Art. 11. Os representantes da nação brazileira são o Imperador e a Assembléia Geral. Art. 12. Todos estes poderes no Império no Brasil são delegações da Nação" (CONSTITUICÃO POLITICA DO IMPERIO DO BRAZIL (de 25 de março de $1824 . \quad$ Disponível em: <http://www.planalto.gov.br/Ccivil_03/Constituiçao/Constituiçao24.htm>. Acesso em: 09 jan. 2001.
} 
interesses da Nação dizendo o que é melhor para o todo, ainda que contrário à vontade dos que o haviam elegido.

No mesmo sentido, anota Pinto Ferreira ${ }^{299}$ sobre a Constituição brasileira de

1946:

Constituição Federal brasileira, seguindo as praxes da tradição republicana, adotou as linhas amplas do govêrno representativo, falando em seu preâmbulo dos "representantes do povo", indicando em seu art. $1^{\circ}$ a preferência pelo "regime representativo", segundo a fórmula de que todo poder emana do povo e em seu nome será exercido, e afinal estatuindo no art. 56 que a Câmara dos Deputados compõe-se de representantes do povo, eleitos, segundo o sistema de representação proporcional, pelos Estados, pelo Distrito Federal e pelos Territórios.

E na sequiência afirma o mesmo autor:

Observa-se francamente uma nítida orientação favorável exclusivamente ao governo representativo, numa antipatia nata pelas tendências da democracia semidireta, encaminhando-se além disso o nosso espírito constitucional pelo rastro da doutrina do mandato livre ou nacional, na conformidade da fórmula anglo-francesa da representação.

A fidelidade partidária instituída pela Emenda Constitucional $\mathrm{n}^{\circ}$ 01/69, especificamente pelo art. $152^{300}$, atenuou essa tendência secular ${ }^{301}$. Posteriormente, a Emenda Constitucional $n^{\circ} 25 / 85$ revogou esse dispositivo e o mandato passou a ser novamente livre.

A Constituição Federal de 1988 manteve a mesma linha, no sentido de que "todo poder emana do povo e em seu nome será exercido", porém, agora, com a presença da figura da democracia semidireta. ${ }^{302}$

\footnotetext{
${ }^{299}$ FERREIRA, Luiz Pinto. op. cit., t. 1, p. 191.

300،Art. 152. Parágrafo único. Perderá o mandato no Senado federal, na Câmara dos Deputados, nas Assembléias Legislativas e nas Câmaras Municipais quem, por atitudes ou pelo voto, se opuser às diretrizes legitimamente estabelecidas pelos órgãos de direção partidária ou deixar o partido sob cuja legenda foi eleito. A perda do mandato será decretada pela Justiça Federal, mediante representação do partido, assegurado o direito de ampla defesa”. (PRESIDÊNCIA DA REPÚBLICA. Disponível em: <www.planalto.gov.br/ccivil/Constituicao/Emendas/Emc_anterior1988?emc01_69.htm>. Acesso em: 09 jan. 2009.

${ }^{301}$ Sobre esse período em que vigeu a fidelidade partidária entre nós, escreve Monica Herman Salem Caggiano: "Não seria por demais observar que, diante da magnitude que assumiu a questão partidária, por reduzido período de tempo a conotação livre do mandato parlamentar foi ofuscada pelo vínculo da fidelidade partidária, princípio erigido a nível constitucional, por força da Emenda no 1/69 à Constituição de 1967. Evidente aí uma certa nuance da tese do mandato imperativo, reforçada, in casu, pela possibilidade do estabelecimento de diretrizes a que o eleito era obrigado a se ater na sua atuação" (CAGGIANO, Monica Herman Salem. Sistemas eleitorais x representação política, cit., p. 34).

${ }^{302} \mathrm{~A}$ nosso ver, como já registrado alhures, hoje, os fundamentos do mandato político são outros.
} 
Todavia, com as recentes decisões do Supremo Tribunal Federal e do Tribunal Superior Eleitoral, que reintroduziram a figura da fidelidade partidária no Brasil, parecenos que a questão do mandato imperativo poderá voltar à tona.

A questão será tratada de forma detalhada mais à frente em tópico específico.

\subsubsection{O sistema eleitoral brasileiro}

\subsubsection{O desenvolvimento do sistema eleitoral brasileiro}

Acerca do desenvolvimento do sistema eleitoral do Brasil, Luís Virgílio Afonso da $\mathrm{Silva}^{303}$ elaborou uma útil divisão de conteúdo histórico, levando em consideração o período de vigência de cada Constituição brasileira, a qual serve de norte para demonstrarmos como se deu a evolução das eleições no País.

No período de vigência da Constituição de 1824 (1824-1891), durante quase todo o período imperial, o sistema eleitoral baseou-se na eleição indireta em dois graus, censitária e com voto a descoberto (voto não-secreto) ${ }^{304}$. Nesse período foram adotadas instruções e leis específicas dispondo sobre o sistema eleitoral baseado na eleição indireta. Cabe observar que o romancista José de Alencar, já em 1859, escrevia artigos jornalísticos demonstrando sua preocupação com as minorias ${ }^{305}$ e, em 1874, na Câmara dos Deputados, consta que o escritor discursou sobre o problema da representação das minorias e que suas palavras serviram de inspiração para elaboração do decreto ${ }^{\circ}$ 2674/1875, conhecido como Lei do Terço $^{306}$, que previa a proteção das minorias ${ }^{307}$. Em 1881 surgiu a Lei Saraiva, estabelecendo eleição direta para deputados em distritos uninominais. O período de

\footnotetext{
${ }^{303}$ SILVA, Luís Virgílio Afonso da. op. cit., p. 99-107.

${ }^{304}$ Maria D'alva Gil Kinzo registra que "este procedimento de voto oral, a descoberto, advinha por um lado da noção corrente na época de que o voto constituía um ato público e uma forma do eleitor manter abertamente suas opiniões, embora, na verdade, funcionasse como uma forma de controlar o voto. Por outro lado, respondia a uma questão prática na medida em que o direito de voto se estendia aos analfabetos." (KINZO, Maria D’alva Gil. op. cit., p. 51).

${ }^{305}$ LIMA JÚNIOR, Olavo Brasil de. op. cit., p. 45.

306“A Lei do Terço acabou com a eleição em distritos. Votava-se antes em listas. Se uma província tinha direito a dez deputados, a pessoa votava em dez nomes. Se tinha direito a quinze, votava em quinze nomes. No Império votava-se por lista e, assim, um partido poderia facilmente controlar a Câmara, se tivesse disciplina. Para evitar tal situação, estabeleceu-se que não se poderia votar na lista completa, ou seja, votava-se em apenas em dois terços dela. Se eram seis vagas votava-se apenas em quatro nomes, deixando o outro terço para que houvesse representação da oposição" (Cf. CARVALHO, José Murilo de. O sistema eleitoral no Império. In: PEIXOTO, João Paulo M.; PORTO, Walter Costa. Sistemas eleitorais no Brasil. Brasília: Instituto Tancredo Neves; Fundação Friedrich Naumann, 1987. p. 15).

${ }^{307}$ SILVA, Luís Virgílio Afonso da. op. cit., p. 101.
} 
vigência da Constituição Imperial foi marcado pelo domínio das oligarquias e fraudes eleitorais. $^{308}$

No período da Constituição de $1891^{309}$ (1891-1934) poucas alterações ocorreram no sistema eleitoral. O fato mais importante desse período foi a previsão de representação das minorias na Constituição ${ }^{310}$, tema esse, aliás, que, como dito, já constava da legislação do período imperial. A eleição direta foi mantida e, em janeiro de 1892, foi promulgada a Lei $\mathrm{n}^{\mathrm{o}} 35$, dispondo que as eleições seriam realizadas em distritos plurinominais de três deputados pelo sistema de voto limitado. Posteriormente, com a Lei n ${ }^{\circ} 1629 / 1904$ o número de deputados por distrito passou para cinco, ainda pelo sistema majoritário e no lugar do voto limitado foi adotado o voto cumulativo. O sistema eleitoral continuou oligárquico e fraudulento. ${ }^{311}$

O período da Constituição de 1934 (1934-1937) já contou com o Código Eleitoral de 1932, que previa a representação proporcional, o voto feminino, secreto, e a criação da Justiça Eleitoral. O Código de 1932 disciplinou a eleição da legislatura de 1935 e da Assembléia Constituinte. ${ }^{312}$

No período do Estado Novo (1937-1946), no qual vigeu a Constituição de 1937, conhecida como Constituição Polaca ${ }^{313}$, no início do regime ditatorial conduzido por Getúlio Vargas, foram instituídas eleições indiretas para deputados federais e estaduais, que não foram levadas adiante. Em 1945 foram realizadas eleições para a Assembleia Constituinte, com base na Lei Constitucional $n^{\circ}$ 9/45 e no Decreto-lei $n^{\circ}$ 7.586/45, atribuindo-se sobras ao partido mais votado na circunscrição, que favoreceu na Constituinte os partidos que apoiavam Getúlio Vargas, apesar de ele já encontrar-se deposto no momento da composição da Constituinte. O Decreto-lei $n^{\circ} 7.5 .86$, conhecido por Lei Agamenon, instituiu a distorção da igualdade de valor entre os votos das diversas

\footnotetext{
${ }^{308}$ SILVA, Luís Virgílio Afonso da. op. cit., p. 101.

${ }^{309}$ Primeira Constituição Republicana.

${ }^{310}$ Constituição de 24 de fevereiro de 1891. "Art. 28. A Câmara dos Deputados compõem-se de representantes do povo eleitos pelos Estados e pelo Distrito Federal, mediante suffragio directo, garantida a representação da minoria". Cf. CONSTITUIÇÃO DA REPÚBLICA DOS ESTADOS UNIDOS DO BRASIL (de 24 de fevereiro de 1891). Disponível em: <http://www.planalto.gov.br/Ccivil_03/Constituicao/Constituiçao91.htm>. Acesso em: 02 jan. 2009.

${ }^{311}$ SILVA, Luís Virgílio Afonso da. op. cit., p. 102-103.

${ }^{312}$ Id. Ibid., p. 103-104.

${ }^{313} \mathrm{~A}$ inspiração do nome veio da Constituição autoritária da Polônia.
} 
regiões do Brasil, devido à fixação de tetos e pisos para o número de deputados por Estado. $^{314}$

Durante a vigência da Constituição de 1946 (1946-1967) manteve-se a representação proporcional e as desigualdades do Decreto-lei no 7.586/45 e, em 1959, surge um novo Código Eleitoral, reintroduzindo as sobras pelo método das maiores médias, conforme já previa a reforma eleitoral de 1935, o que contribuiu para a democratização da representação proporcional. Em 1965 surge o Ato Institucional $\mathrm{n}^{\circ} 2$ com a extinção de todos os partidos políticos e a criação da ARENA e do MDB. ${ }^{315}$

Ainda com apoio na divisão traçada por Luís Virgílio Afonso da Silva, quanto ao período de vigência da Constituição de 1967/69 316 (1967-1988), inicialmente a Constituição de 1967 estabeleceu eleições para a Câmara dos Deputados pelo sistema proporcional, no entanto, nenhuma eleição foi realizada na vigência dessa Constituição. Em 1968 surge o Ato Institucional $n^{\circ} 5$ outorgando poderes ditatoriais ao Presidente de República, autorizando-o a fechar o Congresso Nacional e a exercer funções legislativas integrais. Em 17 de outubro de 1969, com a emenda constitucional $\mathrm{n}^{\mathrm{o}} 1$ foram estabelecidos o sufrágio universal, o voto direto e secreto, salvo nos casos nela previstos (como, por exemplo, para certas funções de chefia do Executivo) e os partidos políticos teriam representação proporcional, total ou parcial, conforme lei reguladora. A expressão "total ou parcial" gerou dúvidas sobre se a Constituição se referia ao sistema misto. Mas, na prática, trabalhou-se com base no sistema proporcional comum. Em 1977, surge a emenda constitucional $\mathrm{n}^{\circ} 8$, aumentando o tamanho das bancadas do Norte e do CentroOeste em detrimento do Sudeste e Sul do País. Houve previsão do sistema proporcional misto, com a emenda constitucional $n^{\circ} 22 / 82$, mas não foi posto em prática. A emenda constitucional $n^{\circ} 25 / 85$ revogou expressamente tal previsão, voltando o sistema a ser o proporcional comum. ${ }^{317}$

Com a Constituição de 1988 o País voltou ao regime democrático, com eleições para todos os Chefes do Executivo e membros de todos os Legislativos da Federação (Congresso Nacional, Assembleias Legislativas Estaduais, Assembleia Legislativa Distrital e Câmara de Vereadores). Os deputados federais e estaduais, bem como os vereadores continuaram sendo eleitos pelo sistema proporcional e os Senadores e

\footnotetext{
${ }^{314}$ SILVA, Luís Virgílio Afonso da. op. cit., p. 104.

${ }^{315}$ Id. Ibid., p. 105.

${ }^{316}$ Que acabou sendo quase que integralmente alterada pela emenda constitucional $\mathrm{n}^{\mathrm{o}}$ 01/69.

${ }^{317}$ SILVA, Luís Virgílio Afonso da. op. cit., p. 106-107.
} 
Chefes de Executivo pelo sistema majoritário, e, nesse último caso, às vezes em dois turnos. No sistema proporcional nacional há "distribuição dos restos pelas maiores médias e a circunscrição coincide com os limites territoriais do Estado". 318

\subsubsection{As eleições realizadas em distritos no Brasil}

Durante parte do século XIX e nas três primeiras décadas do século XX, o Brasil viveu a experiência do sistema majoritário em distritos, conhecido equivocadamente como sistema distrital ou voto distrital, como já registrado anteriormente.

Na Lei dos Círculos (Decreto n 842/1853), as províncias dividiam-se “em tantos distritos quantos fossem os seus deputados à Assembléia Geral”. De 1860 a 1875 os distritos elegiam três deputados e de 1881 a 1889 apenas um deputado era eleito por distrito. A Lei $n^{\circ}$ 35/1892 passou novamente para três deputados por distrito e com a Lei Rosa e Silva, de 1904, o número passou para cinco. 319

Em 1932, o Código Eleitoral instituiu o sistema proporcional, acabando com as eleições realizadas em distritos no Brasil.

Duas tentativas de implantação de eleições por distritos foram realizadas posteriormente. Primeiro, em 1958, o Ministro Edgar Costa apresentou um projeto prevendo eleição por distrito e, em 1964, Franco Montoro apresentou um outro projeto baseado no sistema alemão. ${ }^{320}$

A eleição por distritos voltou a ser cogitada nos Anos Oitenta com a redemocratização e, a partir daí, surgiram propostas de emendas constitucionais e projetos de lei para se instituir novamente o procedimento de eleições por distritos no País, a exemplo das propostas e projetos apresentados pelo Senador Milton Campos e pelos Deputados Franco Montoro e Oscar Corrêa.

Dentre outros, merece destaque o projeto que foi apresentado pelo Deputado Franco Montoro no ano de 1995, o Projeto de Lei $\mathrm{n}^{\mathrm{o}} 1.306 / 95^{321}$, que trazia novamente hipótese semelhante ao sistema adotado na Alemanha.

\footnotetext{
${ }^{318}$ SILVA, Luís Virgílio Afonso da. op. cit., p. 107.

${ }^{319}$ Id. Ibid., p. 99-102.

${ }^{320}$ CAGGIANO, Monica Herman Salem. Sistemas eleitorais x representação política, cit., p. 94-95.

${ }^{321}$ CÂMARA DOS DEPUTADOS. Projetos de Lei e Outras Proposições. Disponível em: $<$ http://www.camara.gov.br/internet/sileg/Prop_lista.asp?Autor+2540\&Limite=N>. Acesso em: 02 jan. 2009.
} 


\subsubsection{O projeto de Lei $n^{0}$ 1.306/95 de autoria do ex-deputado Franco Montoro}

Segundo esse projeto de lei, as eleições para a Câmara dos Deputados e Assembleias Legislativas (incluindo a do Distrito Federal) devem obedecer ao princípio da representação proporcional, fixada com base nos quocientes eleitorais e partidários, sendo que a representação de cada Estado na Câmara dos Deputados e nas Assembleias Legislativas deve ser composta, metade, de nomes eleitos em distritos uninominais, e a outra metade de nomes retirados de listas partidárias. $\mathrm{O}$ número de distritos de cada circunscrição deve ser, tanto para a Câmara dos Deputados e Assembleias Legislativas, igual à metade dos lugares a preencher, elevando-se à unidade superior quando o número de cadeiras for ímpar. Os distritos devem ser equitativamente formados pelos Tribunais Eleitorais (Tribunal Superior Eleitoral e Tribunais Regionais Eleitorais), levando em consideração a contiguidade da área, o número de eleitores, o número de habitantes e a unidade sócioeconômica.

Sobre as candidaturas, dispõe o projeto de lei que somente poderão concorrer às eleições candidatos registrados por partidos e cada um dos partidos poderá registrar apenas um candidato para cada distrito e uma lista partidária, em ordem de procedência, para cada circunscrição. Proíbe-se o registro de um candidato por mais de um distrito, da mesma circunscrição ou de outra, bem como sua inclusão em lista partidária da mesma circunscrição. O candidato registrado por um distrito poderá ser inscrito na lista partidária da mesma circunscrição e esta lista conterá no máximo tantos candidatos quantos representantes correspondem à circunscrição, na ordem que os partidos os desejaria eleitos. Será considerado não-inscrito na lista partidária o nome do candidato que venha a ser eleito por um distrito.

Sobre o procedimento de votação, o Projeto de Lei $n^{\circ}$ 1.306/95 estabelece que cada eleitor disporá de dois votos. O primeiro será atribuído a um dos candidatos registrados no distrito e o segundo, a uma das listas partidárias registradas na circunscrição. Os votos serão separadamente computados, podendo o eleitor votar em candidato do distrito que não pertença ao partido cuja lista preferir.

Finalmente, sobre o resultado da eleição, estabelece que será considerado eleito no distrito o candidato que obtiver o maior número de votos e, em caso de empate, será considerado eleito o candidato mais idoso. A metade das cadeiras, em cada circunscrição, será atribuída na proporção dos votos que obtiveram nas listas partidárias, as demais, pelos 
eleitos por distritos. Os remanescentes da lista serão suplentes de todos os eleitos do partido. Nas eleições pelo sistema de representação proporcional não será permitida a aliança de partidos.

Verifica-se que, de fato, o Projeto de Lei do ex-deputado Franco Montoro buscou inspiração no modelo eleitoral alemão. Portanto, não configura tecnicamente uma proposta de sistema eleitoral misto, mas sim proporcional.

\subsubsection{O mandato partidário. As decisões do Supremo Tribunal Federal e do Tribunal Superior Eleitoral sobre a titularidade do mandato político}

O partido da Frente Liberal, atualmente denominado DEM, apresentou consulta ao Tribunal Superior Eleitoral (CTA-1398), nos seguintes termos:

Considerando o teor do art. 108 da lei no 4.737/65 (Código Eleitoral), que estabelece que a eleição dos candidatos a cargos proporcionais é resultado do quociente eleitoral apurado entre os diversos partidos e coligações envolvidos no certame democrático.

Considerando que é condição constitucional de elegibilidade a filiação partidária, posta para indicar ao eleitor o vínculo político e ideológico dos candidatos.

Considerando ainda que, também o cálculo das médias, é decorrente do resultado dos votos válidos atribuídos aos partidos e coligações.

INDAGA-SE:

Os partidos e coligações têm o direito de preservar a vaga obtida pelo sistema eleitoral proporcional, quando houver pedido de cancelamento de filiação ou de transferência do candidato eleito para outra legenda? $?^{322}$

Por decisão do Plenário do Tribunal Superior Eleitoral ${ }^{323}$, conforme Resolução $\mathrm{n}^{\mathrm{o}}$ 22.526, de 27 de março de 2007, por maioria de 6 votos a 1, ficou definido que os partidos políticos e as coligações conservam o direito à vaga obtida pelo sistema proporcional, quando houver pedido de cancelamento de filiação ou de transferência do candidato eleito por um partido para outra legenda, significando isso, na prática, que os mandatos obtidos nas eleições pelo sistema proporcional (i.e., para deputados federais, distritais, estaduais e vereadores) pertencem ao partido político.

\footnotetext{
${ }^{322}$ TRIBUNAL SUPERIOR ELEITORAL. Disponível em: <http://www.tse.gov.br/internet/index.html>. Acesso em: 30 dez. 2008.

${ }^{323}$ Id. Ibid.
} 
Trechos do voto do relator do caso ${ }^{324}$ demonstram quais fundamentos foram utilizados para se chegar à conclusão de que o mandato pertence ao partido político:

(...) Ora, não há dúvida nenhuma, quer no plano jurídico, quer no plano prático, que o vínculo de um candidato ao Partido pelo qual se registra e disputa uma eleição é o mais forte, se não o único, elemento de sua identidade política, podendo ser afirmado que o candidato não existe fora do Partido Político e nenhuma candidatura é possível fora de uma bandeira partidária.

Por conseguinte, parece-me equivocada e mesmo injurídica a suposição de que o mandato político eletivo pertence ao indivíduo eleito, pois isso equivaleria a dizer que ele, o candidato eleito, se teria tornado senhor e possuidor de uma parcela da soberania popular, não apenas transformando-a em propriedade sua, porém mesmo sobre ela podendo exercer, à moda do exercício de uma prerrogativa privatística, todos os poderes inerentes ao seu domínio, inclusive o de dele dispor.

Todavia, parece-me incogitável que alguém possa obter para si - e exercer como coisa sua - um mandato eletivo, que se configura essencialmente como uma função política e pública, de todo avessa e inconciliável com pretensão de cunho privado. (...)

(...) Não se há de permitir que seja o mandato eletivo compreendido como algo integrante do patrimônio privado de um indivíduo, de que possa ele dispor a qualquer título, seja oneroso ou seja gratuito, porque isso é a contrafação essencial da natureza do mandato, cuja justificativa é a função representativa de servir, ao invés da de servir-se. ${ }^{325}$

Contra os efeitos da Resolução $n^{\circ}$ 22.526/07 foram impetrados mandados de segurança (mandados de segurança $n^{\circ}$ 26.602/DF, 26.603/DF e 26.604/DF) perante o Supremo Tribunal Federal, que, ao final, houve por bem confirmar a postura do Tribunal Superior Eleitoral, decidindo que a desfiliação partidária "sem justa causa" enseja a perda do mandato político. ${ }^{326}$

Nesse contexto, o Tribunal Superior Eleitoral aprovou, em 25 de outubro de 2007, a Resolução $22.160^{327}$, prevendo que “o partido interessado pode pedir, perante a Justiça Eleitoral, a decretação da perda do cargo eletivo em decorrência de desfiliação partidária sem justa causa”.

\footnotetext{
${ }^{324}$ Ministro Cesar Asfor Rocha.

${ }^{325} \mathrm{O}$ ministro Marcelo Ribeiro, voto divergente, alegou que não há previsão constitucional nem em lei ordinária permitindo a perda de mandato do parlamentar nas hipóteses de cancelamento de filiação partidária ou troca de partido, invocando o art. 55 da Constituição Federal, que, na sua opinião, apresenta um rol taxativo sobre as hipóteses de perda de mandato, não havendo a previsão aplicada ao caso.

${ }^{326}$ SUPREMO TRIBUNAL $\quad$ FEDERAL. Disponível em: $<$ http://www.stf.jus.br/portal/jurisprudencia/visualizarEmenta.asp?s1=000369043\&base=baseAcordaos $>$. Acesso em: 10 jan. 2009.

${ }^{327}$ TRIBUNAL SUPERIOR ELEITORAL. Resolução $\mathrm{n}^{\circ}$ 22.610. Disponível em: <http://www.tse.gov.br/internet/partidos/fidelidade_partidaria/res22610.pdf>. Acesso em: 30 dez. 2008.
} 
Enquanto não houver lei específica, valerão as decisões do Supremo Tribunal Federal e do Tribunal Superior Eleitoral

Fato é que, com essas decisões, o mandato passou a ter novamente um vínculo, agora com o partido político, devendo o representante fidelidade às instruções deste último e não ao povo, à nação ou à circunscrição eleitoral. Como afirma Bonavides, "fazer a vinculação do representante ao seu partido é sem dúvida o primeiro passo que se dá para assentar a imperatividade definitiva do mandato". 328

Muito embora as decisões do Supremo Tribunal Federal e do Tribunal Superior Eleitoral tenham terminado com a infidelidade partidária, em razão do caráter oligárquico dos partidos, elas tendem a fortalecer o círculo estreito de seus dirigentes. ${ }^{329}$

\subsubsection{Autoridades que podem ser submetidas ao recall}

Para se determinar quem pode ser submetido ao procedimento de recall e, para chegarmos a uma conclusão compatível com a nossa realidade histórica, política e social, é necessário, antes disso, verificar quem exerce função pública no Brasil.

Hely Lopes Meirelles expendeu clássicas lições sobre o gênero e as espécies de agentes que exercem funções estatais. ${ }^{330}$

O gênero corresponde ao termo "agentes públicos" que "são todas as pessoas físicas incumbidas, definitivamente ou transitoriamente, do exercício de alguma função estatal”331, que se repartem em cinco espécies: agentes políticos, agentes administrativos, agentes honoríficos, agentes delegados e agentes credenciados.

Nas palavras do referido administrativista, agentes políticos são:

os componentes do governo nos seus primeiros escalões, investidos em cargos, funções, mandatos ou comissões, por nomeação, eleição,

\footnotetext{
${ }^{328}$ BONAVIDES, Paulo. op. cit., p. 221.

${ }^{329}$ Cf. FERREIRA FILHO, Manoel Gonçalves. op. cit., p. 93.

${ }^{330}$ Os autores de Direito Administrativo não possuem opiniões coincidentes sobre o tema, mas fez-se a opção pela lição de Hely Lopes Meirelles por ser a mais conhecida e aplicada no direito brasileiro. Para demonstrar tal divergência, apenas a título exemplificativo, registre-se que Celso Antônio Bandeira de Mello divide os agentes públicos (Gênero) em (a) agentes políticos, (b) servidores estatais, que se subdividem em servidores públicos e servidores das pessoas governamentais de direito privado, (c) particulares em colaboração com a Administração e (d) concessionários e permissionários de serviços públicos, bem como delegados de função de ofício público. Para o referido autor, os juízes, promotores, membros dos Tribunais de Contas e representantes diplomáticos não são agentes políticos (MELLO, Celso Antonio Bandeira de. Curso de direito administrativo. São Paulo: Malheiros Ed., 2002. p. 227-235).

${ }^{331}$ MEIRELLES, Hely Lopes. Direito administrativo brasileiro. 34. ed. atual. por Eurico de Andrade Azevedo, Délcio Balestero Aleixo e José Emmanuel Burle Filho. São Paulo: Malheiros Ed., 2008. p. 76.
} 
designação ou delegação para o exercício de atribuições constitucionais. Esses agentes atuam com plena liberdade funcional, desempenhando suas atribuições com prerrogativas e responsabilidades próprias, estabelecidas na Constituição e leis especiais. Têm normas específicas para sua escolha, investidura, conduta e processos crimes funcionais e de responsabilidade que lhe são privativos.

E ainda:

exercem funções governamentais, judiciais e quase-judiciais, elaborando normas legais, conduzindo os negócios públicos, decidindo e atuando com independência nos assuntos de sua competência. São autoridades supremas do Governo e da Administração na área de sua atuação, pois não estão hierarquizadas, sujeitando-se apenas aos graus e limites constitucionais e legais da jurisdição. Em doutrina, os agentes políticos têm plena liberdade funcional, equiparável à independência dos juízes nos seus julgamentos, e, para tanto, ficam a salvo de responsabilização civil por seus eventuais erros de atuação, a menos que tenham agido com culpa grosseira, má-fé ou abuso de poder. ${ }^{332}$

Exemplos de agentes políticos, na lição do mesmo autor, são os Chefes do Poder Executivo das entidades da Federação (Presidente da República, Governadores Estaduais e do Distrito Federal e os Prefeitos Municipais) e seus auxiliares diretos (Ministros, Secretários de Estado e do Distrito Federal, e Secretários Municipais), bem como os membros das Casas Legislativas (Senadores, Deputados Federais, Deputados Estaduais e Vereadores), os membros do Poder Judiciário (Ministros do Supremo Tribunal, Ministros do Superior Tribunal de Justiça, Magistrados Federais, Distritais e Estaduais), os membros do Ministério Público (Procuradores da República, Procuradores de Justiça Estaduais e Promotores e Curadores Públicos Estaduais), os membros dos Tribunais de Contas (federal, estaduais e, em alguns casos, municipais), os representantes diplomáticos e quaisquer outras autoridades que com independência funcional no desempenho de suas atribuições constitucionais e governamentais, não fazem parte do quadro do serviço público. $^{333}$

Os agentes administrativos, por sua vez, são pessoas físicas vinculadas ao Estado ou às suas autarquias e fundações por relações exclusivamente profissionais, sujeitos à hierarquia em razão da função exercida e submetidos ao regime jurídico próprio da entidade estatal a que estão vinculados. Não são membros do Poder do Estado, não representam nenhum poder e não exercem atribuições políticas ou governamentais,

\footnotetext{
${ }^{332}$ MEIRELLES, Hely Lopes. op. cit., p. 77.

${ }^{333}$ Id. Ibid., p. 79.
} 
constituindo a grande massa de prestadores de serviços à Administração direta e indireta do Estado, classificados, segundo o art. 37, incisos II, V e IX da Constituição Federal em servidores públicos concursados, servidores exercentes de cargos ou empregos em comissão, titulares de cargo ou emprego público e servidores temporários, contratados por tempo determinado para atender à necessidade de temporário e excepcional interesse público. $^{334}$

Agentes honoríficos "são cidadãos convocados, designados ou nomeados para prestar, transitoriamente, determinados serviços ao Estado, em razão de sua condição cívica, de sua honorabilidade ou de sua notória capacidade profissional, mas sem qualquer vínculo empregatício ou estatutário e, normalmente, sem remuneração"335, tais como o mesário eleitoral ou o jurado convocado para o Tribunal do Júri.

Por fim, há os agentes delegados que são pessoas físicas ou jurídicas, que recebem do Estado, em princípio por meio de procedimento licitatório, uma incumbência para execução de obras, atividades ou serviços públicos, a serem realizados em nome próprio, por conta e risco do agente delegado (chamados de concessionários, permissionários ou autorizados), segundo regras estatais e sujeitos à fiscalização contínua da entidade estatal delegante; e há também os agentes credenciados que são pessoas que recebem a incumbência de representar a Administração Pública em ato específico ou para prestar atividade específica por meio de remuneração do poder público credenciante. ${ }^{336}$

Dessas cinco espécies de agentes públicos, apenas os agentes políticos representam o governo, exercendo mandatos ou funções constitucionais. Portanto, é sobre essa espécie, os agentes políticos, que pode o recall ser aplicado, mas não sobre todos eles.

Para aplicação do instituto do recall, diferentemente do que ocorre nos Estados Unidos, entre nós há de haver a justa premissa de que este instrumento só poderá ser aplicado aos casos em que o exercente da função pública ou do mandato tenha sido nomeado ou empossado em decorrência de uma votação popular. A premissa é o voto popular. Como o recall se qualifica como um direito político, tal direito somente pode ser exercido após a eleição, depois de um determinado período, sobre as pessoas que conquistaram a posição de representante por meio do voto do eleitor. Se o povo pode eleger, ele também pode destituir, desde que de acordo com uma lei reguladora dessa

\footnotetext{
${ }^{334}$ MEIRELLES, Hely Lopes. op. cit., p. 80-81.

${ }^{335}$ Id. Ibid., p. 81.

${ }^{336}$ Id., loc. cit.
} 
situação. Dessa forma, aplicar-se-ia o mecanismo apenas aos Chefes dos Executivos das pessoas políticas da Federação (ou seja, Presidente da República, Governadores de Estado e do Distrito Federal, e Prefeitos Municipais) e membros do Legislativo dessas mesmas entidades (Senadores, Deputados Estaduais, Deputados Distritais e Vereadores), afastada a aplicação do instituto para todos e quaisquer juízes, membros do Ministério Público, membros dos Tribunais de Contas e representantes diplomáticos.

Portanto, a arma recall somente poderia ser utilizada nessas hipóteses, contra membros do Executivo e do Legislativo de todas as entidades da Federação. A forma para viabilizar a aplicação do instituto dependerá do tipo de entidade (pessoa política) a que o agente político estiver vinculado e do sistema eleitoral, conforme será demonstrado a seguir. $^{337}$

\subsection{A questão da viabilidade do recall no direito brasileiro}

$\mathrm{O}$ art. 14 da Constituição Federal Brasileira prevê o referendo, o plebiscito e a iniciativa popular como mecanismos de democracia semidireta e a Lei $n^{\circ}$ 9.709/98 regula esses três institutos.

Apesar de existirem na ordem jurídica, tais mecanismos não são utilizados na vida política do País, principalmente porque a Lei $n^{\circ}$ 9.079/98 não estimula a utilização destes procedimentos.

Para que o recall seja viável no Brasil, é necessário, em primeiro lugar, acrescentá-lo no rol do art. 14 da Constituição Federal, com a denominação que lhe é própria da língua inglesa, sem criação de nomes ou adaptações linguísticas, para que fique bem claro que se trata do instituto sobre o qual se busca inspiração no direito norteamericano. O Recall é, da mesma forma que o termo impeachment, universal, e deve significar "revogação de mandato político por decisão dos eleitores".

Além disso, é preciso que seja editada uma lei específica regulando o instituto, sem ideologias e reivindicações de esquerda ou de direita, tendo como princípios a soberania popular e o desenvolvimento do País com base na honesta e competente Administração Pública, ideia essa inspirada em um dos fundamentos do recall norte-

\footnotetext{
${ }^{337} \mathrm{Em}$ decorrência dos poderes expressos e implícitos das prerrogativas inerentes à cidadania, havendo prova de abuso de poder econômico, corrupção ou fraude, Maria Garcia sustenta a possibilidade de revogação do mandato mediante iniciativa do cidadão (Cf. GARCIA, Maria. Os poderes do mandato e o recall. Revista de Direito Constitucional e Internacional, São Paulo, ano 13, p. 36-38, jan./mar. 2005).
} 
americano. A lei não deverá ser ideológica, mesmo porque as ideologias do passado não são as mesmas do século XXI.

O recall não significará a volta do mandato imperativo. Apesar de as decisões do Supremo Tribunal Federal e do Tribunal Superior Eleitoral terem afirmado que o mandato político é de propriedade do partido (o que, aliás, fortalece a velha partidocracia), a atuação política deve ser pautada não apenas nos interesses partidários (que muitas vezes não coincidem com o interesse público), mas, antes de tudo, na dignidade da pessoa humana, na ética e na responsabilidade política, pois quem atua em nome do interesse público deve saber que seus atos podem favorecer ou prejudicar milhares ou milhões de pessoas, daí porque a responsabilidade política deve ser entendida como uma responsabilidade mais importante do que qualquer outra. O Direito deverá passar a regular a responsabilidade política não só pelo aspecto do direito administrativo, mas também pelo aspecto institucional, daí porque o recall deve ser estabelecido como um instrumento de controle político a ser utilizado por eleitores responsáveis para remoção de agentes políticos, eleitos, irresponsáveis.

Dentro desse contexto, servirá também como verdadeira forma de expressão da oposição política, responsável, e não para a oposição inconsequente, sem medidas. Por fim, existe, hoje, o caráter pessoal da relação de representação, os candidatos invadem as casas dos eleitores através dos meios de comunicação, fazem inúmeras promessas e, depois de eleitos, deixam de dar satisfação às pessoas Não se representa mais a nação. Também não se representa o partido. O que deve ser representado por aquele que exerce função pública eletiva é o interesse público, o bem comum, que corresponde ao interesse dos eleitores.

Além disso, o recall não deve ser inserido no sistema político de forma aleatória, pois certamente não funcionará, como acontece hoje com o referendo, o plebiscito e a iniciativa popular. É preciso que o instituto seja inserido dentro de um contexto de reforma institucional e constitucional, baseado na autonomia política dos entes federativos e na modificação do sistema eleitoral, apesar das dificuldades naturais que existem nos níveis estaduais e no nacional em função do espaço geográfico e grande número de eleitores envolvidos.

A instauração do recall nos Municípios é o primeiro passo para sua adoção no País, por razões práticas, históricas e culturais. 


\subsubsection{Municípios}

\subsubsection{O desenvolvimento do Município no Estado Brasileiro}

Desde suas origens o Município sempre esteve em posição de destaque na formação do Estado Brasileiro.

Ao colonizar o Brasil, Portugal trouxe para sua colônia o seu modelo de Municípios, com considerável margem de autonomia no que dizia respeito às atribuições políticas, administrativas e judicantes, não obstante houvesse um conflito entre as comunidades locais (que pretendiam aumentar a autonomia dos Municípios) e os representantes da Coroa e das Capitanias. ${ }^{338}$

Sobre essa época, Hely Lopes Meirelles ${ }^{339}$ registra que:

No período colonial a expansão municipalista foi restringida pela idéia centralizadora das capitanias, afogando as aspirações autonômicas dos povoados que se fundavam e se desenvolviam mais pelo amparo da Igreja que pelo apoio dos donatários. Mesmo assim, as Municipalidades de então tiveram inegável influência na organização política que se ensaiava no Brasil, arrogando-se, por iniciativa própria, relevantes atribuições de governo, de administração e de justiça. Realizavam obras públicas, estabeleciam posturas, fixavam taxas, nomeavam juízes-almotacéis, recebedores de tributos, depositários públicos, avaliadores de bens penhorados, alcaides-quadrilheiros, capitães-mores de ordenanças, sargentos-mores, capitães-mores de estradas, juízes da vintena e tesoureiros-menores. Julgavam injúrias verbais, e nas raras vezes, num incontido extravasamento de poder, chegaram essas Câmaras a decretar a criação de arraiais, a convocar juntas do povo para discutir e liberar sobre interesses da Capitania, a exigir que governadores comparecessem aos seus povoados para tratar de negócios públicos de âmbito estritamente local, a suspender governadores de suas funções e até mesmo depô-los, como fez a Câmara do Rio de Janeiro com Salvador Correia de Sá e Benevides, substituído por Agostinho Barbalho Bezerra.

Durante a fase colonial, em que pese a existência de conflitos, a verdade é que, como a Coroa efetivamente não se interessava pela sua colônia, os Municípios se fortaleceram. Como bem assinala Dalmo de Abreu Dallari ${ }^{340}$, cabia ao Município, nessa fase da história brasileira, resolver praticamente todos os seus problemas, inclusive os de

\footnotetext{
${ }^{338}$ ALMEIDA, Fernando Dias Menezes. Consideraçoes sobre os Municípios no Brasil. In: TAVARES, André Ramos; FERREIRA, Olavo A. V. Alves; LENZA, Pedro. Constituição Federal 15 anos: mutação e evolução - comentários e perspectivas. São Paulo: Ed. Método, 2003. p. 313.

${ }^{339}$ MEIRELLES, Hely Lopes. Direito municipal brasileiro, cit., p. 36-37.

${ }^{340}$ DALLARI, Dalmo de Abreu. A reforma constitucional e as novas competências dos Estados e Municípios, cit., p. 40.
} 
segurança externa (como, e.g., o enfrentamento dos invasores estrangeiros), além de cuidar do abastecimento, da construção de estradas, de casas, dos problemas de incêndio, educação e saúde, dentre outros assuntos. Ou seja, tudo era resolvido no Município. Havia uma descentralização extrema.

Maria Garcia ${ }^{341}$ observa que os Municípios "como unidades administrativas e políticas, constituíram os únicos órgãos de representação popular, daí a soma dos seus poderes e a sua importância na Colônia e nos primeiros tempos de Império: eram as Câmaras, efetivamente, a única força politicamente estruturada de participação governamental".

Portanto, durante o período colonial e início do Império, os Municípios eram os centros políticos, sociais e econômicos do Brasil.

Dalmo de Abreu Dallari ${ }^{342}$ ensina que, a partir da vinda do Príncipe Dom João para o Brasil, em 1808, a Coroa Portuguesa atraiu as competências e os poderes para o governo central. A partir daí ocorreram ao longo dos séculos XIX e XX alternação de períodos de centralização e descentralização de competências.

Em que pese as mudanças constitucionais e legais ocorridas, outorgando maiores ou menores competências aos Municípios brasileiros, é fato incontestável que o Brasil possui uma tradição municipal secular, uma tradição muito antiga de autonomia municipal.

Com a promulgação da Constituição Federal de 1988, a posição dos Municípios foi substancialmente alterada.

\subsubsection{O Município dentro da estrutura federativa}

A vigente Constituição Federal alterou de forma significativa a situação dos Municípios brasileiros, incluindo-os ao lado da União, dos Estados e do Distrito Federal como entidades componentes da Federação.

De fato, ao compulsarmos os art. $1^{\circ}$ e 18 da Constituição, verifica-se que a República Federativa do Brasil é formada pela União indissolúvel dos Estados e

\footnotetext{
${ }^{341}$ GARCIA, Maria. Federalismo brasileiro: a repartição de rendas tributárias e o Município. In: BASTOS, Celso (Coord.). Por uma nova Federação. São Paulo: Ed. Revista dos Tribunais, 1995. p. 130.

${ }^{342}$ DALLARI, Dalmo de Abreu. A reforma constitucional e as novas competências dos Estados e Municípios, cit., p. 41.
} 
Municípios, bem como do Distrito Federal e, além disso, está expresso que a organização político-administrativa da República Federativa do Brasil compreende a União, os Estados, o Distrito Federal e os Municípios, todos autônomos, nos termos da Constituição.

José Afonso da Silva ${ }^{343}$ assinala que:

nos termos, pois, da Constituição, o Município brasileiro é entidade estatal integrante da Federação, como entidade político-administrativa, dotada de autonomia política, administrativa e financeira. Essa é uma peculiaridade do Município brasileiro. A inclusão do Município na estrutura da Federação teria que vir acompanhada de conseqüências, tais como o reconhecimento constitucional de sua capacidade de autoorganização mediante cartas próprias e ampliação de sua competência, com a liberação de controles que o sistema vigente até agora lhe impunha especialmente por via de leis orgânicas estaduais pelos Estados.

E mais:

(..) no Brasil, o sistema constitucional eleva os Municípios à categoria de entidades autônomas, isto é, entidades dotadas de organização e governos próprios e competências exclusivas. Com isso, a Federação brasileira adquire peculiaridade, configurando-se, nela, realmente, três esferas governamentais: a da União (Governo Federal), a dos Estados Federados (Governos Estaduais) e a dos Municípios (Governos Municipais), além do Distrito Federal, a que agora a Constituição conferiu autonomia.

A Constituição, no seu art. 34, VII, “c”, prevê também a autonomia municipal como prerrogativa intangível, podendo inclusive autorizar a intervenção federal para mantê-la ou restaurá-la, quando postergada pelo Estado-membro. ${ }^{344}$

Ainda sobre as competências e a autonomia municipal, registra Odilon de Andrade $^{345}$ que, "delimitada a esfera de competência de cada uma das entidades administrativas - União, Estado e Município - nenhuma interpenetração pode haver entre elas; nesse sentido é que se diz que, no âmbito de suas atribuições, o Município está acima do Estado e da União, só podendo refreá-lo o Judiciário, por ação própria, quando comete excessos".

Portanto, o Município no Brasil, hoje, possui configuração sui generis e constitui-se entidade componente da Federação, com autonomia política, administrativa e

\footnotetext{
${ }^{343}$ SILVA, José Afonso da. Curso de direito constitucional positivo, cit., p. 639-641.

${ }^{344}$ MEIRELLES, Hely Lopes. Direito municipal brasileiro, cit., p. 93.

${ }^{345}$ ANDRADE, Odilon de. RDA 19/22 apud MEIRELLES, Hely Lopes. Direito municipal brasileiro, cit., p. 93.
} 
financeira, consistindo a autonomia política no poder de auto-organização (elaboração de sua própria lei orgânica, eletividade de seus agentes políticos (eleição de Prefeitos, Viceprefeitos e Vereadores), poder de legislar (editar leis e expedir decretos) de forma exclusiva $^{346}$ ou comum ${ }^{347}$, poder de fiscalizar, etc. A autonomia administrativa, por sua vez, compreende a administração própria, organização dos serviços públicos locais e a ordenação do território, e a autonomia financeira consiste na decretação de tributos e aplicação de rendas municipais.

Não há hierarquia na organização federativa, União, Estados, Distrito Federal e Municípios encontram-se no mesmo nível. Os assuntos próprios dos Municípios são por eles mesmos tratados, i.e., os assuntos de interesse local são de competência dos Municípios, que são entidades autônomas, de acordo com a Constituição Federal.

\subsubsection{O recall no contexto do governo municipal}

Deve ser levado em consideração o fato de que existe uma tradição secular no Brasil de governo municipal.

Há um costume antigo nos Municípios brasileiros de determinar e gerir os assuntos de seus interesses. A população do Município, principalmente dos pequenos e médios, está acostumada a acompanhar a vida cotidiana da cidade. As pessoas estão acostumadas com o processo eleitoral e depois de escolhidos os representantes ocorre um natural desenvolvimento e acompanhamento da vida política. Os eleitores vêem o Prefeito chegar à Prefeitura, sabem o horário que ele entra e sai do expediente, assim como o de seus auxiliares mais diretos. Em geral, os Prefeitos e Vereadores comparecem aos eventos sociais, às rádios e prestam esclarecimentos à população. ${ }^{348}$

Há casos, entretanto, nos quais os agentes políticos municipais não prestam contas de sua gestão e acabam se envolvendo em corrupção, crimes e atos absolutamente imorais. Muitas vezes, para evitar uma cassação de mandato, o prefeito suborna os vereadores ou os próprios edis se confabulam entre si para evitar punições políticas. $\mathrm{O}$

\footnotetext{
${ }^{346}$ Poder de legislar sobre assuntos de interesse local, suplementar a legislação federal e estadual, etc.

${ }^{347}$ Competência comum com a União e os Estados-membros, como, por exemplo, nos termos do art. 23 da Constituição, preservar florestas, a fauna e a flora, bem como proteger o meio ambiente.

${ }^{348}$ Como bem observa Monica Herman Salem Caggiano, "podemos inferir o sufrágio, a nível municipal, como aquele que, de forma mais eficaz assegura valor às vontades expressas pelos votos depositados nas urnas. Sem qualquer ingerência de mecanismos e artifícios, nesse setor, cada cidadão detém parcela participativa igual na seleção do Chefe do Executivo (prefeito e vice-prefeito) e dos membros do legislativo" (CAGGIANO, Monica Herman Salem. Sistemas eleitorais x representação política, cit., p. 73).
} 
resultado disso é que a população fica com um sentimento de revolta, frustrada e com as mãos atadas. Há um sentimento popular de falta de representação e de ausência de controle político.

Além disso, pelo lado institucional, a Constituição de 1998 já preparou o caminho para o aperfeiçoamento do governo municipal, incluindo os Municípios como entidades componentes da Federação brasileira, com autonomia política, administrativa e financeira. Dentre outros aspectos, a autonomia política do Município está diretamente relacionada à questão da eleição de seus agentes políticos. E é exatamente neste ponto que se pode falar em recall em nível municipal.

O melhor caminho para evitar transtornos e desconfortos tanto para as autoridades públicas como para a população em geral, para que exista segurança jurídica, é a modificação da Constituição Federal para permitir a figura do recall como mecanismo de democracia semidireta, num primeiro momento aplicável apenas em nível municipal e, posteriormente, se depois de três anos, constatar-se que o instituto trouxe bons resultados à democracia brasileira, poderia, assim, ser estendido ao nível regional e nacional, desde que reformulado o sistema eleitoral.

Os Municípios brasileiros, em sua maioria, são pequenos e médios, com menos de cem mil habitantes, o que significa que, em princípio, não há necessidade de alteração do sistema eleitoral no Brasil para instituição do recall. ${ }^{349}$ Nesses Municípios, pequenos e médios, o recall já poderia fazer parte da primeira fase da reforma política, excepcionando os Municípios com mais de cem mil habitantes que somente entrariam numa segunda fase, junto com os Estados e Municípios, depois de três anos.

Para viabilizar o recall nos pequenos e médios Municípios, seria conveniente a edição de uma lei nacional estabelecendo parâmetros para adoção do instituto nos Municípios com menos de cem mil habitantes. Assim, por exemplo, a lei nacional poderia estabelecer que o Município com menos de cem mil habitantes, que tiver interesse de inserir em sua lei orgânica o mecanismo do recall, poderá previamente realizar um plebiscito para decisão dos eleitores locais sobre a conveniência ou não de adoção desse mecanismo. Poderá também constar da lei nacional simplesmente a possibilidade dos Municípios instituírem em suas leis o recall, sem necessidade de plebiscito ou posterior referendo, evitando, assim, custos para as municipalidades.

\footnotetext{
${ }^{349}$ Se esses Municípios (pequenos e médios) fossem divididos em distritos, obviamente, a aplicação do recall seria muito mais fácil.
} 
Nesse mesmo diploma nacional poderia ser estabelecido, também, para orientação dos Municípios, uma margem percentual de 5\% (cinco por cento) a $15 \%$ (quinze por cento) de assinaturas de eleitores, para dar início ao mecanismo de recall, ficando a critério de cada Município decidir, dentro desse parâmetro, qual percentual será adotado para deflagração do procedimento.

Ademais, essa lei nacional poderia estabelecer as hipóteses mínimas para dar ensejo ao mecanismo, tais como indícios de prática de atos de corrupção, desvio de dinheiro público, fraude, compra (e venda) de votos e indícios de prática de crimes em geral, inclusive a incompetência administrativa no caso de patente inatividade, prática de atos administrativos imotivados e ausência de gastos mínimos nas áreas de saúde e educação, inclusive flagrante desrespeito à responsabilidade fiscal legal. A eleição de recall poderia ser presidida pelo juiz da comarca, assistida pelo membro local do Ministério Público, com auxílio do Tribunal Regional Eleitoral. O Prefeito ou o Vereador seria destituído do cargo na hipótese de o recall receber o apoio da maioria dos eleitores. Uma caução deverá ser exigida da pessoa física ou do grupo que der início à coleta das assinaturas para a deflagração do recall e, se for comprovada má-fé na deflagração do instituto, o Tribunal Regional Eleitoral deverá cancelar o título ou os títulos de eleitores daqueles que deram início ao procedimento, mediante processo específico. O recall somente poderá ser requerido após um ano, contado da assinatura do termo de posse do Prefeito ou Vereador. No caso de recall de Prefeitos, na cédula eleitoral haverá duas perguntas aos eleitores. A primeira será se o Prefeito deverá ser destituído ou não da função pública e a segunda sobre quem deverá substituí-lo, exatamente como ocorre no Estado da Califórnia. Com relação aos Vereadores, constará da cédula apenas a questão sobre a destituição. O suplente deverá assumir no lugar do vereador destituído.

Dessa forma, o recall pode ser utilizado nos Municípios de acordo com a vontade dos munícipes e de acordo com princípios constitucionais que regem a autonomia municipal.

Ademais, na forma como está apresentado acima, trata-se praticamente de figura idêntica, senão, no mínimo irmã gêmea, do recall norte-americano e talvez seja essa a única maneira de este instituto tornar-se efetivamente viável no Brasil, pois, nas demais entidades políticas (grandes Municípios, Estados e em nível nacional) a dificuldade será consideravelmente maior, levando em conta o número de pessoas e custos envolvidos. 
O recall é um instituto que foi idealizado para o nível municipal norteamericano, o que, do nosso ponto de vista, corresponde à nossa expectativa. No Brasil, sua utilização em nível local seria um bom teste para esse mecanismo, num primeiro momento apenas para os Municípios menores, mesmo dentro do sistema de representação proporcional.

\subsubsection{O recall nos Estados-membros e em nível nacional}

É inquestionável que é muito mais fácil, lógico, viável e econômico convocar os eleitores, dentro de um distrito, que necessariamente corresponde a um espaço geográfico menor, para avaliar o trabalho ou comportamento de um Deputado (federal ou estadual) ou Vereador (principalmente nos grandes Municípios) e, se for o caso, submetêlo a um procedimento de recall.

$\mathrm{Na}$ forma como hoje está concebido o sistema (proporcional), por exemplo, se fosse instituído o recall no Estado de São Paulo, no caso dos deputados estaduais, todos os eleitores do Estado deveriam, após a petição ter obtido o número de assinaturas necessárias, comparecer às urnas para decidir se o mandato de determinado deputado deveria ser revogado ou não. Isso, obviamente, implicaria grande movimentação de pessoas e dispêndio de recursos públicos, considerando que quem arcaria com os gastos seria o próprio Estado, uma vez que o recall é uma eleição.

Portanto, a nosso sentir, a forma mais viável de se instituir o recall dos parlamentares (Deputados) nos níveis estadual e nacional, seria por meio da alteração do sistema proporcional para o majoritário em distritos uninominais. A proposta que foi apresentada por Franco Montoro em 1995, conjugada com uma alteração da Constituição Federal, também tornaria exeqüível o instituto do recall, mas não se pode negar que pelo sistema majoritário acima referido a sua instituição se daria de forma mais simplificada e efetiva.

Quanto aos Chefes do Executivo e Senadores, não há que se falar na alteração do sistema eleitoral, uma vez que o majoritário parece ser o único possível para a eleição desses agentes políticos, existindo necessidade apenas de alteração da Constituição Federal, para permitir o recall para essas autoridades públicas. Por evidente, o recall do Presidente da República, dos Governadores, dos Prefeitos (nos Grandes Municípios) e dos Senadores será sempre muito difícil, pelas mesmas razões que foram acima expostas 
quanto às dificuldades existentes para o recall dos deputados federais e estaduais no sistema proporcional. 


\section{CONCLUSÕES}

Definir representação política, de fato, constitui tarefa árdua, pois, como registrou Sartori ${ }^{350}$, a representação "cobre todo o percurso que vai da política ao direito, e vice-versa".

Há na representação um fortíssimo conteúdo político, relacionado ao poder, que dificulta a determinação precisa de sua essência.

No entanto, parece-nos claro que sua natureza não pode ser perseguida com os olhos direcionados apenas para o passado, pelo menos não como fator predominante nessa busca. Deve-se atentar também ao presente e ao futuro.

Aquele que se arvorar em determinar a essência da representação não poderá deixar de considerar a tecnologia nas eleições (i.e., o processo eleitoral tecnológico, com os rápidos resultados das pesquisas de opinião e das votações, os quais geram extremo dinamismo nas decisões políticas), a vida imediatista decorrente da tecnologia dos meios de comunicação e da internet (que produzem uma velocidade jamais pensada no processo de comunicação entre os seres humanos), a presença dos candidatos nas casas dos eleitores por essas mesmas vias de comunicação fazendo inúmeras promessas aos necessitados (que gera nos eleitores uma sensação de proximidade com os candidatos), a tendência natural de crescimento da participação popular nas decisões do Estado, a altíssima (e, às vezes, de legalidade duvidosa) tributação levada a efeito pelo Estado, a corrupção e a ineficiência deste, a corrupção partidária e eleitoral, as questões ambientais e, tudo isso, conjugado também com a importância que assume hoje a questão da responsabilidade e ética na política, a necessidade de prestação de contas e a dignidade da pessoa humana.

Esse conjunto de fatores leva-nos a crer que há a necessidade de haver um vínculo, não aquele vínculo medieval ou aquele existente entre o partido político e o representante, mas uma relação de responsabilidade que se impõe naturalmente na vida social. Isso faz com que o aspecto jurídico da representação se torne mais relevante, mais presente, para exigir dos representantes comportamentos éticos e responsáveis, em conformidade com o interesse público (que não deixa de ser também o interesse maior dos eleitores).

${ }^{350}$ SARTORI, Giovanni. op. cit., p. 16. 
Devemos sair da Caverna de Platão e começar a perceber o que está acontecendo em nossa volta e o que está por vir.

Em que pese o que foi dito acima, certas referências ao passado, que foram apresentadas nesta tese, devem ser novamente evocadas.

$\mathrm{O}$ mandato imperativo esteve diretamente relacionado às instruções e estas pressupõem que quem as determina já possui conhecimento prévio daquilo que o governo deverá decidir. ${ }^{351}$ Durante o Período Medieval e no início da Idade Moderna, a representação funcionou com base nas instruções prévias. Inicialmente, poucas classes sociais se reuniam nos conselhos para discutir questões políticas e leis, principalmente aquelas relacionadas à tributação. Não existiam assembléias permanentes. Existiam apenas os estados-gerais que eram convocados excepcionalmente. Os representantes eram instruídos previamente pelos representados. O mandatário deveria cumprir aquilo que já estava pré-determinado no mandato e, obviamente, se houvesse a quebra da relação de confiança, o mandante estaria plenamente autorizado a revogar o mandato conferido. $\mathrm{O}$ representante possuía autorização para agir em nome do representado somente nos termos dos poderes que lhe fora outorgado. Caso surgissem novas questões no instante em que o mandatário estivesse representando o mandante, nenhuma decisão poderia ser tomada até que novas instruções fossem repassadas.

Com o crescimento das classes burguesas na Europa nos séculos XVII e XVIII surgem novas concepções sobre a representação para acabar com o sistema das instruções. Especialmente na França, "acabar com o mandato imperativo" significava acabar com a forma pela qual a nobreza e o clero se faziam representar. Assim, a representação torna-se abstrata. $\mathrm{O}$ representante não representa mais o mandante e sim a nação. $\mathrm{O}$ mandato passa a ser denominado "representativo" ou "livre".

Nos Estados Unidos a prática das instruções foi muito difundida, caindo em desuso nas primeiras décadas do século XIX. O governo representativo surge para assegurar a res publica e o sistema de freios e contrapesos se consolida como forma de manutenção do equilíbrio governamental. Os parlamentares e principalmente os membros do Congresso passam a ser independentes, não se obrigando a buscar instruções no eleitorado. Tais ideias passaram a ser a base da democracia norte-americana, pelo menos pelo aspecto macro.

\footnotetext{
${ }^{351}$ MANIN, Bernard. The principles of representative government, cit., p. 166.
} 
O século XIX caracterizou-se pelos questionamentos da representação. E vários fatores contribuíram para isso, tais como a ampliação do direito de sufrágio, a ascensão política do proletariado e o surgimento dos partidos políticos. Surgem novas ideias e teorias, fala-se em substância e caráter descritivo da representação, em coletividade organizada que age por meio de seus órgãos, representação das minorias, igualdade política e proporcionalidade na representação. Por outro lado, a teoria marxista, nesse mesmo século, resgata a ideia de revogação dos mandatos dos representantes, em oposição aos ideais burgueses e ao mandato representativo.

No final do século XIX e começo do século XX, os problemas do capitalismo se intensificam, principalmente a corrupção e o tráfico de influência. Os partidos políticos se multiplicam e a representação política passa a ser entendida conjuntamente com este fenômeno. Os partidos passam a ser instrumentos da representação. Por outro lado, os mecanismos de democracia semidireta começam a ser utilizados no Velho Continente e nas primeiras décadas do século XX tais práticas se proliferam.

Nessa mesma época, nos Estados Unidos, os movimentos sociais e determinadas agremiações, inspiradas na velha tradição de participação popular norteamericana, na democracia suíça e até nos ideais de esquerda, criam um mecanismo democrático ao qual deram o nome de recall, para combater a corrupção e incompetência das autoridades públicas regionais e locais. Esse instituto possibilitava, ainda, a revogação de decisões judiciais porque havia também muita corrupção no Judiciário, desencadeada pelo poder econômico das corporações empresariais. Esse instituto denominado recall, ao longo do século XX, com fundamento na autonomia política dos Estados e das entidades locais, desenvolveu-se principalmente nos pequenos centros urbanos dos Estados Unidos e jamais foi instituído em nível nacional. Além desses objetivos vinculados ao controle do poder político e eficiência da Administração Pública, o recall também se apresentava como uma forma de aproximação entre os eleitores e os eleitos.

Em geral, as opiniões contrárias ao instituto são no sentido de que se trata de uma negação do princípio republicano, pois o mandato deve ser julgado pelo povo apenas nas próximas eleições. Entende-se também que o recall sacrifica a estabilidade governamental e confere muito poder aos eleitores, prejudicando a independência do governante. Argumenta-se também que há problemas quanto ao mérito das acusações (i.e., existem legislações estaduais que não estabelecem as hipóteses fáticas para o 
procedimento) e que o recall torna a função pública menos atraente para as pessoas competentes.

Os problemas reais do instituto, nos Estados Unidos, a nosso ver, dizem respeito à dificuldade de obtenção do número mínimo de assinaturas exigido pelas legislações (principalmente em nível estadual), ao eventual uso político do recall e ao custo do procedimento.

Quanto às opiniões favoráveis sobre o instituto, constatamos existirem alegações no sentido de que o recall é um sistema permanente de controle das autoridades públicas, aumenta a sensibilidade dos governantes aproximando-os dos eleitores, tende a tornar o governo mais representativo e a diminuir a troca de favores com o poder econômico, aproxima os cidadãos das questões públicas, é uma alternativa ao impeachment (principalmente porque este processo político sofre influências e pode ser controlado pelas autoridades públicas), tende a melhorar a eficiência da Administração Pública (principalmente das pequenas cidades) por meio da aplicação do "good business principle", além de ser o corolário lógico do direito de sufrágio.

Embora existam aspectos contrários e favoráveis ao recall, em geral, hoje, nos Estados Unidos, os eleitores rejeitam o uso político (eleitoreiro) do mecanismo. Além disso, o recall desperta um grande interesse nos eleitores, havendo um elevado nível de participação do eleitorado nessas eleições especiais (o que significa que há efetivamente uma aproximação entre os políticos e os eleitores, e que o recall desperta nos cidadãos o interesse pelos assuntos públicos). Sua utilização ocorre basicamente nas pequenas cidades. Vale lembrar, ainda, que o sistema eleitoral norte-americano facilita a aplicação desse instituto.

Mesmo com as dificuldades naturais do instituto, nos Estados Unidos, desde 1903, já ocorreram mais de 2.000 casos de destituição de autoridades (a maioria em nível local), o que equivale, em média, a quase 20 destituições por ano naquele País. Portanto, dentro dessa estatística, entendemos que não é possível afirmar que esse instituto é pouco utilizado nos Estados Unidos. Se compararmos com o nosso País, cabe-nos indagar: quantas vezes tivemos processos de impeachment no Brasil?

Hoje, nos Estados Unidos, o recall é utilizado preponderantemente em nível local, para destituição de membros das Casas Legislativas e diretores de escolas. O instituto raramente é adotado para revogação de mandatos de juízes e promotores. Em mais 
de cem anos apenas dois governadores foram destituídos nos Estados Unidos. Por analogia ao nosso sistema, podemos dizer que se trata de um instituto de direito municipal, relacionado à Administração pública honesta e eficiente.

Outrossim, calha registrar que existem Estados norte-americanos que permitem o recall para autoridades públicas indicadas ou nomeadas, ou seja, autoridades não-eleitas, mas a regra continua sendo sua aplicação para as autoridades eleitas.

A nosso sentir, o recall (mecanismo típico, puro) existe hoje apenas nos Estados Unidos e em British Columbia, no Canadá. Os demais institutos existentes na América Latina, África e Ásia (com exceção do Japão que possui um método próprio para destituição de juízes) foram inspirados no sistema de revogação de mandatos dos países socialistas.

Há quem afirme que o instituto do recall resgata o antigo mandato imperativo. Seguindo nessa linha, Paulo Bonavides afirma que:

Onde o direito de revogação existe, a democracia representativa, volvida
em democracia semidireta, já admite juridicamente o mandato
imperativo, que nos demais sistemas de influência democrática
dominante configura-se apenas como realidade de fato, repousando
porém em bases políticas e morais, a um passo já de sua ulterior e
próxima institucionalização jurídica.
Pelo aspecto meramente formal, o mandato imperativo, ao ter ingresso
numa determinada ordem constitucional, como a de certos regimes semi-
representativos, se converte em mais um aspecto ilustrativo daquela
tendência, já notada por eminentes juristas, segundo a qual certos
institutos do direito público têm inversamente caído sob o efeito de uma
"jusprivatização", observada pelo menos com vistas a algumas
características formais. ${ }^{352}$

Não compartilhamos dessa ideia. O recall não significa a simples readmissão do mandato imperativo. Há outros elementos em jogo. Não há que se falar também no mandato representativo da França do Século XVIII, nem no mandato partidário. O mandato se encontra no centro de toda construção jurídica da república. ${ }^{353}$ E esta, implica, essencialmente, cidadania, legitimidade, igualdade, participação, responsabilidade, prestação de contas, dignidade da pessoa humana, probidade, pluralidade e transparência. O fundamento do recall não é o caráter imperativo do mandato (relacionado ao direito privado) e sim os princípios acima mencionados, que fundamentam a própria república. $\mathrm{O}$

\footnotetext{
${ }^{352}$ BONAVIDES, Paulo. op. cit., p. 264.

${ }^{353}$ ATALIBA, Geraldo. op. cit., p. 91.
} 
mandato imperativo pressupõe que os eleitores conheçam previamente os assuntos que serão deliberados pelos governantes. Isso é impossível nos dias atuais. Na Idade Média era assim que funcionava a relação entre representantes e representados, com instruções prévias. Hoje essa prática não é mais possível. O mandato imperativo nada tem a ver com o recall. O mandato do recall é o mandato democrático, responsável e ético.

Feitas essas considerações, cabe-nos, então, neste momento, apresentar uma definição própria de recall:

O recall é um mecanismo de democracia semidireta, típico dos Estados Unidos da América, adotado no início do século XX em determinados Estados da Federação norte-americana para combater a corrupção e incompetência das autoridades públicas, principalmente em nível local. Caracteriza-se como direito político do cidadão, não sendo permitida sua utilização contra autoridades federais. $\mathrm{O}$ mecanismo existe atualmente em 18 Estados norte-americanos e o seu procedimento básico consiste numa primeira fase de coleta de assinaturas dos eleitores, mediante caução prévia em dinheiro e, após a obtenção de um percentual mínimo de assinaturas válidas, resulta numa segunda fase na qual se realiza, de modo geral, uma eleição especial para destituir (e substituir) autoridades públicas estaduais e municipais (geralmente eleitas, inclusive juízes) ou para revogar decisão judicial (de juízo monocrático ou de segundo grau de jurisdição) que tenha negado a aplicação de lei, sendo que sua utilização hoje, nos Estados Unidos, ocorre principalmente em nível local, onde se permite, inclusive, seu uso excepcional para destituição de diretores de escolas.

Quanto à sua inserção na ordem jurídica brasileira, pelo nosso ponto de vista, há desvantagens e vantagens.

Pelo aspecto negativo, o recall diminui a liberdade do representante que poderá, em certas circunstâncias, em razão de sentimentos exacerbados da comunidade, tomar decisões inadequadas sobre questões complexas e de maior repercussão. No entanto, esse aspecto torna-se relativo, uma vez que a liberdade dos representantes no Brasil tornouse sinônimo de impunidade e de irresponsabilidade. Há ainda a questão do custo para realização de um procedimento de recall. Por fim, existem os problemas da grande dimensão do país e do sistema eleitoral proporcional, que dificultam a aplicação do instituto no Brasil. Por isso, sua aplicação em nível local é mais efetiva.

O primeiro argumento favorável é que o recall constitui excelente mecanismo para o eleitorado fiscalizar os seus representantes, principalmente se for considerado o fato de que a corrupção ocorre no Brasil de forma desenfreada. O eleito, sabendo que pode ser removido de sua função, tenderá a ser mais responsável e a agir de forma mais transparente 
e competente, prestando contas de seus atos e, de certa forma, ficará mais próximo, efetivamente, de suas bases eleitorais, alcançando melhores resultados ao interesse público. Ainda, pelo aspecto positivo do instituto, pode-se dizer que, existindo maior controle do eleito, a tendência é que ocorra diminuição dos casos de corrupção e a consequência disso, em larga escala, significa o aumento de receita para os cofres públicos. Além disso, o recall é um instrumento que comprovadamente se presta à melhoria da qualidade da cidadania dos indivíduos, pois aproxima os eleitores dos assuntos de natureza pública.

Não obstante o acima exposto, considerando que a rápida evolução social é um fato presente em nossas vidas, com o desenvolvimento das sociedades e das tecnologias, os velozes processos de informação, a tendência é que o instituto do recall passe a ser inserido nas ordens jurídicas dos países, para promover o incremento do controle popular e da cidadania. Mesmo não sendo utilizado em larga escala, o caráter preventivo do mecanismo é salutar. O recall é uma "arma que deve ficar atrás da porta".

Além disso, como salientamos no início desta tese, a democracia indireta é a forma pela qual tem se manifestado a soberania popular e a representação tem apresentado muitos problemas. Há várias formas para aperfeiçoá-la, seja pelo aprimoramento do sistema eleitoral, seja por meio de investimentos e incentivos em educação e em cidadania, dentre esses incentivos encontra-se o recall, que, não se pode negar, aproxima os políticos dos eleitores e se qualifica como mecanismo de controle do poder político, respeitada sua natureza e seus limites naturais.

No Brasil, o recall, a nosso ver, só pode ser aplicado aos agentes políticos eleitos pelo voto popular, isto é, os Chefes dos Executivos (Presidente da República, Governadores e Prefeitos) e aos membros do Legislativo (Senadores, Deputados e Vereadores). O recall no Brasil só é possível, portanto, para revogação dos mandatos políticos dessas autoridades, mediante decisão dos eleitores.

Levando esses aspectos em consideração, bem como outros que foram levantados ao longo desta tese, no Brasil, o recall há de ser permitido pela Constituição Federal para os pequenos e médios municípios brasileiros (ou seja, para aqueles com menos de 100.000 habitantes) com base na autonomia dessas entidades. Vale lembrar, aqui, novamente, que o recall é tradicionalmente um instrumento local e os nossos Municípios possuem longa história de autonomia e gestão de seus próprios interesses. A 
nosso ver, portanto, o recall é um instrumento interessante e importante que merece ser inserido no sistema jurídico brasileiro, principalmente no âmbito municipal.

No caso, para viabilizar essa hipótese, uma emenda constitucional deve alterar os art. 14 e 30 da Constituição Federal para permitir o recall em nível municipal para os pequenos e médios Municípios, conforme registramos alhures. Uma experiência dessa espécie certamente renderá bons frutos para as comunidades locais, mesmo sem a alteração do sistema eleitoral. Certamente não irá corrigir a representação política local, mas com certeza haverá maior aproximação entre eleitores e eleitos, gerando maior participação dos cidadãos nas questões públicas. Além disso, servirá também como um excelente mecanismo de controle contra a corrupção, atos ilícitos em geral e até contra a ineficiência administrativa. Para torná-lo efetivo, uma lei nacional deve, como já salientamos, estabelecer as bases do recall para os pequenos e médios Municípios, definindo um parâmetro para os números de assinaturas necessárias para deflagração do mecanismo, as hipóteses fáticas que permitirão a utilização do procedimento, os valores da caução para o requerimento, as penalidades aplicáveis aos eleitores que se utilizarem do recall de forma inadequada, bem como todo o detalhamento do procedimento eleitoral, dentre outros assuntos.

Como dito, o recall foi instituído para o nível municipal norte-americano. Da mesma forma, é interessante para a democracia brasileira sua utilização em nível local. Seria um bom teste para esse mecanismo, num primeiro momento apenas para os Municípios médios e pequenos, mesmo dentro do sistema de representação proporcional. Posteriormente, após três anos de sua implantação, numa segunda fase, o instituto poderá ser inserido nas demais entidades da Federação, observadas certas condições.

Em nível nacional e estadual e até para os grandes municípios, o recall não funcionará se não houver uma alteração do sistema eleitoral, permitindo as eleições em distritos. O sistema majoritário em distritos uninominais é o mais adequado para o processamento do recall. As dimensões do território brasileiro e dos Estados, bem como o número de eleitores envolvidos e o sistema eleitoral hoje existente praticamente impossibilitam a utilização do recall nesses níveis. Portanto, a implementação do recall nessas entidades políticas deve ser acompanhada de uma reforma no sistema eleitoral.

Por fim, entendemos que o recall não é um instituto para ser utilizado de forma irresponsável pelos cidadãos. Sua utilização deve ser direcionada apenas para situações 
sérias como, por exemplo, corrupção, prática de atos ilícitos e imorais e patente incompetência administrativa. O recall pode ser utilizado, nas hipóteses, por exemplo, de a autoridade pública ser flagrada em atos de corrupção, quando houver fortes indícios de atos ilícitos ou quando houver flagrante de crime (como já ocorreu poucos anos atrás, no caso em que os vereadores de uma cidade do interior de São Paulo praticavam em quadrilha a exploração sexual de crianças).

O recall é um mecanismo que aproxima os eleitores das questões públicas e é um excepcional instrumento de controle, e deve ser utilizado por eleitores responsáveis contra eleitos irresponsáveis. 


\section{REFERÊNCIAS BIBLIOGRÁFICAS}

AIETA, Vânia Siciliano. O recall e o voto destituinte. Revista de Direito Constitucional e Internacional, São Paulo, v. 10, n. 40, p. 157-170, jul./set. 2002.

ALMEIDA, Fernando Dias Menezes. Considerações sobre os Municípios no Brasil. In: TAVARES, André Ramos; FERREIRA, Olavo A. V. Alves; LENZA, Pedro. Constituição Federal 15 anos: mutação e evolução - comentários e perspectivas. São Paulo: Ed. Método, 2003.

AQUINO, Rubim Santos Leão et al. História das sociedades modernas às sociedades atuais. Rio de Janeiro: Record, 2001.

OS ARTIGOS federalistas (1787/1788): James Madison, Alexander Hamilton, John Jay. Ed. integral. Tradução: Maria Luiza X. de A. Borges. Rio de Janeiro: Nova Fronteira, 1993.

ATALIBA, Geraldo. República e constituição. São Paulo: Malheiros Ed., 1998.

AZAMBUJA, Darcy. Teoria geral do Estado. 35. ed. São Paulo: Globo, 1996.

BARTHÉLEMY, Joseph; DUEZ, Paul. Traité elémentaire de droit constitutionnel. Paris: Dalloz, 1926.

BEARD, Charles E; SHULTZ Bill E. Documents on state-wide: initiative, referendum and recall. New York: The Macmillan Company, 1912.

BENEVIDES, Maria Victoria de Mesquita. A cidadania ativa: referendo, plebiscito e iniciativa popular. São Paulo: Ática, 2000.

BLACK'S Law Dictionary. Saint Paul: Editorial Staff, 1933.

. Seventh Edition. Bryan A. Garner Editor. St. Paul, Minnesotta: West Group, 1999.

BOBBIO, Norberto. Estado, governo e sociedade. São Paulo: Paz e Terra, 1987.

. O futuro da democracia. São Paulo: Paz e Terra. 2000.

. Teoria geral da política: a filosofia política e a lição dos clássicos. Organizado por Michelangelo Bovero. Tradução de Daniela Beccaria Versiani. Rio de Janeiro: Campus, 2000 . 
BONAVIDES, Paulo. Ciência política. Rio de Janeiro: Forense, 1983.

. Ciência política. 10. ed. rev. e atual. São Paulo, Malheiros Ed., 1999.

. Teoria constitucional da democracia participativa: por um direito constitucional de luta e resistência, por uma nova hermenêutica, por uma repolitização da legitimidade. São Paulo: Malheiros Ed., 2001.

BROSSARD, Paulo. O impeachment. Porto Alegre: Oficinas Gráficas do Globo, 1965.

BURKE, Edmund. Discurso a los electores de Bristol. In: Textos políticos. Versión española e introducción de Vicente Herrero. México: Fondo de Cultura Económica, 1942.

CAETANO, Marcello. Manual de ciência política e direito constitucional. 6. ed. rev. e ampl. por Miguel Galvão Teles. Coimbra: Almedina, 1996. t. 1.

CAGGIANO, Monica Herman Salem. Direito parlamentar e direito eleitoral. Barueri, SP: Manole, 2004.

Oposição na política: propostas para uma rearquitetura da democracia. São Paulo: Angelotti, 1995.

. Sistemas eleitorais x representação política. 1987. Tese (Doutorado) - Faculdade de Direito, Universidade de São Paulo, São Paulo, 1987.

CALIMAN, Auro Augusto. Mandato parlamentar: aquisição e perda antecipada. São Paulo: Atlas, 2005.

O recall no Estado de São Paulo. Revista de Informação Legislativa, Brasília, v. 42, n. 165, p.197-203, jan./mar. 2005.

CAMPILONGO, Celso Fernandes. Representação política. São Paulo: Ática, 1988.

CANOTILHO, José Joaquim Gomes. Direito constitucional e teoria da Constituição. 4. ed. Coimbra: Almedina, 2000.

CARVALHO, José Murilo de. O sistema eleitoral no Império. In: PEIXOTO, João Paulo M.; PORTO, Walter Costa. Sistemas eleitorais no Brasil. Brasília: Instituto Tancredo Neves; Fundação Friedrich Naumann, 1987.

CAVALCANTI, Themistocles Brandão. Teoria do Estado. Rio de Janeiro: Borsoi, 1958.

COMPARATO, Fábio Konder. A nova cidadania. Lua Nova: revista de cultura e política São Paulo, n. 289, p. 85-106, 1993. 
COULANGE, Fustel de. A cidade antiga: estudos sobre o culto, o direito; as instituições da Grécia e Roma. Tradução de Jonas Camargo Leite e Eduardo Fonseca. São Paulo: Hemus, 1975.

CRONIN, Thomas E. Direct democracy: the politics of the initiative, referendum and recall. Cambridge MA: Harvard University Press, 1999.

CUNHA, Sérgio Sérvulo da. O que é voto distrital. Porto Alegre: Sergio Antonio Fabris, 1991.

DALLARI, Dalmo de Abreu. Elementos de teoria geral do Estado. São Paulo: Saraiva, 2000 .

. O Estado Federal. São Paulo: Ática, 1986.

. O futuro do Estado. 2. ed. rev. e atual. São Paulo: Saraiva, 2007.

A reforma constitucional e as novas competências dos Estados e Municípios. In:

SEMINÁRIO PACTO FEDERATIVO E AS RELAÇÕES INTERGOVERNAMENTAIS.

Curitiba. Anais... Curitiba: IMAP, 1995.

DAVID, René. Os grandes sistemas do direito contemporâneo. São Paulo: Martins Fontes, 2002.

DI RUFFIA, Paolo Biscaretti. Direito constitucional (instituições de direito público). Tradução de Maria Helena Diniz. Revisão de Ricaro Olivo. São Paulo: Ed. Revista dos Tribunais, 1984.

DUVERGER, Maurice. Os partidos políticos. Tradução de Cristiano Monteiro Oiticica. Rio de Janeiro: Zahar Editores, 1970.

EKIRCH JR., Arthur A. A democracia americana: teoria e prática. Tradução de Álvaro Cabral e Constantino Paleólogo. Rio de Janeiro: Zahar, 1965.

ENGELS, Friedrich. A Guerra Civil na França. Introdução de F. Engels. Disponível em: $<$ http://www.ebooksbrasil.org/eLibris/guerracivil.html>.

- Texto de introdução de A Guerra Civil na França. Disponível em: <http://www.ebooksbrasil.org/eLibris/guerracivil.html>. Acesso em: 06 jan. 2009.

FERREIRA, Luiz Pinto. Princípios gerais do direito constitucional moderno. 4. ed. São Paulo: Saraiva, 1962. t. 1.

FERREIRA, Luiz Pinto. Princípios gerais do direito constitucional moderno. 3. ed. rev. e ampl. e atual. São Paulo: Saraiva, 1975. t. 2. 
FERREIRA FILHO, Manoel Gonçalves. Curso de direito constitucional. 32. ed. rev. e atual. São Paulo: Saraiva, 2006.

FRANCO, Afonso Arinos de Melo. Representação popular. In: SEMINÁRIO SOBRE MODELOS ALTERNATIVOS DE REPRESENTAÇÃO POLÍTICA NO BRASIL. Brasília: Ed. da UnB, 1981.

GARCIA, Maria. Federalismo brasileiro: a repartição de rendas tributárias e o Município. In: BASTOS, Celso (Coord.). Por uma nova Federação. São Paulo: Ed. Revista dos Tribunais, 1995.

- Os poderes do mandato e o recall. Revista de Direito Constitucional e Internacional, São Paulo, ano 13, p. 36-38, jan./mar. 2005.

GRESPAN, Jorge Luis da Silva. Revolução Francesa e iluminismo: a crítica radical do "Espírito das Luzes". Críticos, céticos e românticos: uma nova ordem social. 1. ed. São Paulo: Contexto, 2008.

HAURIOU, André. Derecho constitucional e instituciones políticas. Traducción castellana, adaptación y apéndice a cargo de José Antonio Gonzáles Casanova. Barcelona: Ediciones Ariel, 1971.

Le droit de revocatión populaire. Revue Politique et Parlementaire, Paris, t. 70, juil./sept. 1924.

HOAR, Roger Sherman. Advantages of the recall, July, 1909. In: SELECTED articles of the recall compiled by Julia E. Johnsen. Minneapolis: The H. W. Wilson Company, 1901. Disponível em: <http://www.archive.org/details/selectedarticles00johnrich>. Acesso em: 22 dez. 2008.

HOBBES, Thomas. O Leviatã ou matéria: forma e poder de um Estado eclesiástico e civil. Tradução de João Paulo Monteiro e Maria Beatriz Nizza da Silva. São Paulo: Nova Cultural, 1999.

HOBSBAWN, Eric J. A era dos impérios: 1875-1914. Traduçao de Sieni Maria campos e Yolanda Steidel de Toledo. 11. ed. Rio de Janeiro: Paz e Terra, 2007.

A era das revoluções. Tradução de Maria Tereza Lopes e Marcos Penchel. 23. ed. Rio de Janeiro: Paz e Terra, 1977.

HORTA, Raul Machado, As novas tendências do federalismo e seus reflexos na Constituição brasileira de 1988. Revista do Legislativo, n. 25, p. 19-20, jan./mar. 1999. 
Disponível em: <http://www.almg.gov.br/RevistaLegis/Revista25/raul25.pdf>. Acesso em: 10 jan. 2009.

JELLINEK, G. Teoria general del Estado. Tradución y prólogo de la 2. ed. alemana por Fernando de los Rios Urruti. Granada: Editorial Comares, 2000.

KELSEN, Hans. Teoria geral do direito e do Estado. Tradução de Luís Carlos Borges. 3. ed. São Paulo: Martins Fontes. 1998.

KINZO, Maria D’alva Gil. Representação política e sistema eleitoral no Brasil. São Paulo: Edições Símbolo, 1980.

LAMOUNIER, Bolívar. Reflexões filosóficas e considerações políticas sobre os modelos de representação: uma visão comparada. In: SEMINÁRIO SOBRE MODELOS ALTERNATIVOS DE REPRESENTAÇÃO POLÍTICA NO BRASIL, Painel II. Brasília: Ed. da UnB, 1980.

LÊNIN, Vladimir. Estado e a revolução. Prefácio de Florestan Fernandes. Cultura Brasil. Disponível em: <http://www.culturabrasil.org/zip/oestadoearevolucao.pdf.Página 84>. Acesso em: 12 jan. 2009.

LIMA JÚNIOR, Olavo Brasil de. Instituições políticas democráticas: o segredo da legitimidade. Rio de Janeiro: Jorge Zahar, 1997.

LOCKE, John. Segundo tratado sobre o governo civil e outros escritos: ensaio sobre a origem, os limites e os fins verdadeiros do governo civil. Tradução de Magda Lopes e Marina Lobo da Silva. Petrópolis, RJ: Vozes. 1999.

LOEWENSTEIN, Karl. Teoria de la constitución. Traducción y estúdio sobre la obra por Alfredo Gallego Anabitare. Barcelona: Ediciones Ariel, 1965.

MANIN, Bernard. As metamorfoses do governo representativo. Tradução de Vera Pereira. <HTTP://www.anpocs.org.br/portal/publicacoes/rbcs29_01>. Acesso em: 02 dez. 2008.

The principles of representative government. Cambridge: Cambridge University Press, 1997.

MARX, Karl. A Guerra Civil na França. Anexo III. eBooksBrasil. Disponível em: <http://www.ebooksbrasil.org/eLibris/guerracivil.html>. Acesso em: 06 jan. 2009.

MEIRELLES, Hely Lopes. Direito administrativo brasileiro. 34. ed. atual. por Eurico de Andrade Azevedo, Délcio Balestero Aleixo e José Emmanuel Burle Filho. São Paulo: Malheiros Ed., 2008. 
Direito municipal brasileiro. 12. ed. atual. por Célia Marisa Prendes e Márcio Schneider Reis. São Paulo: Malheiros Ed., 2001.

MELlO, Celso Antonio Bandeira de. Curso de direito administrativo. São Paulo: Malheiros Ed., 2002.

MELLO, Leonel Itaussu Almeida. John Locke e o individualismo liberal. In: WEFFORT, Francisco C. (Org.). Os clássicos da política: Maquiavel, Hobbes, Locke, Montesquieu, Rousseau e "O Federalista”. 13. ed. São Paulo: Ática, 2001.

MELLO, Oswaldo Aranha Bandeira de. Natureza jurídica do Estado Federal. São Paulo: Prefeitura Municipal de São Paulo, 1948.

MENEZES, Aderson de. Teoria geral do Estado. 8. ed. rev. e atual. por José Lindoso. Rio de Janeiro: Forense, 1998.

MICHAELIS. Dicionário ilustrado: inglês-português. Impresso em Portugal: Melhoramentos, 2000.

MILL, John Stuart. O governo representativo. Tradução: E. Jacy Monteiro. 2. ed. São Paulo: Ibrasa, 1993.

MIRANDA, Francisco Cavalcanti Pontes de. Comentários à Constituição de 1946. 2. ed. rev. e aum. São Paulo: Max Limonad, 1953. v. 2.

MONTESQUIEU, Charles Secondat, Baron de. O Espírito das leis. Tradução de Cristina Murachco. São Paulo: Martins Fontes, 1996.

MUNRO, William Bennett. The government of the United States: national, state and local. 5. ed. New York: The MacMillan Company, 1949.

PERRY, Marvin. Civilização ocidental: uma história concisa. Tradução de Waltensir Dutra e Silvana Vieira. 2. ed. São Paulo: Martins Fontes, 1999.

PITKIN, Hannah Fenichel. El concepto de representacion. Tradução de Ricardo Montoro Romero. Madrid: Centro de Estudios Constitucionales, 1985.

Representação: palavras, instituições e idéias. Lua Nova, n. 67. 2006. Disponível em: <http://www.scielo.br/pdf/ln/n67/a03n67.pdf>. Acesso em: 02 dez. 2008.

REALE, Miguel. A teoria jurídica da representação política. In: SEMINÁRIO SOBRE MODELOS ALTERNATIVOS DE REPRESENTAÇÃO POLÍTICA NO BRASIL, Painel II, Brasília: Ed. da UnB, 1980. 
ROUSSEAU, Jean-Jacques. O contrato social. Tradução: Antonio de Pádua Danesi. 3. ed. São Paulo: Martins Fontes, 1996.

SARTORI, Giovanni. A teoria da representação no Estado representativo moderno. Traduzido por Ernesta Gaetani e Rosa Gaetani. Revista Brasileira de Estudos Políticos, Belo Horizonte, 1962.

SCHWARTZ, Bernard. O federalismo norte-americano atual: uma visão contemporânea. Tradução de Elcio Cerqueira. Rio de Janeiro: Forense, 1984.

SIÉYÈS, Emmanuel. Que es el tercero Estado? Introdución, tradución y notas de Francisco Ayala. Madrid: Aguilar Ediciones, 1973.

SILVA, Daniela Romanelli da. Democracia e direitos políticos. São Paulo: Instituto de Direitos Políticos, 2005.

SILVA, José Afonso da. Curso de direito constitucional positivo. São Paulo: Malheiros Ed., 2001.

. O sistema representativo, democracia direta e democracia representativa. Revista do Advogado, São Paulo, v. 23, n. 73, p. 94-108, nov. 2003.

SILVA, Luís Virgílio Afonso da. Sistemas eleitorais: tipos, efeitos jurídico-políticos e aplicação ao caso brasileiro. São Paulo: Malheiros Ed., 1999.

SOUZA, José Pedro Galvão de. Da representação política. Tese (Livre Docência de Teoria Geral do Estado) - Faculdade de Direito, Universidade de São Paulo, São Paulo, 1971.

SPIVAK, Joshua. California's recall: adoption of the grand bounce for elected officials. California History, v. 81, n. 2, 2004.

TEIXEIRA, J. H. Meirelles. Curso de direito constitucional. Texto revisto e atualizado por Maria Garcia. Rio de Janeiro: Forense, 1991.

TEMER, Michel. Democracia e cidadania. São Paulo: Malheiros Ed., 2006.

TOCQUEVILLE, Alexis de. A democracia na América. Tradução Eduardo Brandão. 2. ed. São Paulo: Martins Fontes, 2005. Livro1. Leis e costumes.

TRIGUEIRO, Osvaldo. O regime dos Estados na união americana. Rio de Janeiro: Companhia Ed. Americana, 1942.

URBANO, Maria Benedita Malaquias Pires. O referendo: perfil histórico-evolutivo do instituto; configuração do referendo em Portugal. Coimbra: Coimbra Ed., 1998. 
WILCOX, Delos F. Government by all the people or the initiative, the referendum and the recall as instrumet of democracy. New York: The MacMillan Company, 1912.

WOOD, Gordon S. A democracia e a Constituição. In: GOLDWIN, Robert A.; SCHAMBRA, William A. (Eds.). A Constituição norte americana. Prefácio de Paulo Bonavides. Rio de Janeiro: Forense Universitária, 1986.

\section{DOCUMENTOS ELETRÔNICOS}

ACE Electoral Knowledge Network. Disponível em: <http://www.aceproject.org>.

ALASKA Statute. Title 15. Elections. Disponível em: $<$ http://touchngo.com/lglcntr/akstats/Statutes/Title15.htm>. Acesso em: 18 dez. 2008.

BELARUS CONSTITUTION. Disponível em: $<$ http://www.president.gov.by/en/press 10669.html>. Acesso em: 25 jan. 2009.

BRITISH COLUMBIA LAWS. Disponível em: <www.bclaws.ca/Recon/document/ID/freeside/96398_02>. Acesso em: 25 jan. 2009.

CALIFORNIA Law. Disponível em: <http://www.leginfo.ca.gov/cgibin/calawquery?codesection=\&elec\&codebody=hits=20>. Acesso em: 22 dez. 2008.

CÂMARA DOS DEPUTADOS. Assembléia Nacional Constituinte. Disponível em: <http://www.camara.gov.br/internet/constituicao20anos/DocumentosAvulsos/vol-74.pdf>. Acesso em: 13 jan. 2009.

—. Projetos de Lei e Outras Proposições. Disponível em: $<$ http://www.camara.gov.br/internet/sileg/Prop_lista.asp?Autor+2540\&Limite=N>. Acesso em: 02 jan. 2009.

CBC.ca.

em: <http://www.cbc.ca/news/story/1998/06/23/reistma980623a.html>. Acesso em: 13 jan. 2009.

CONSTITUCIÓN POLÍTICA DEL PERÚ. Disponível em: <http://www.tc.gob.pe/legconperu/constitucion.html>. Acesso em: 18 dez. 2008.

CONSTITUCIÓN DE LA REPÚBLICA BOLIVARIANA DE VENEZUELA. Disponível em: <http://www.analitica.com/BITBLIO/anc/constitucion1999.asp>. Acesso em: 18 dez. 2008. 
CONSTITUCIÓN DE LA REPUBLICA DE CUBA. Disponível em: <http://www.cuba.cu/gobierno/cuba.htm>. Acesso em: 26 dez. 2008.

CONSTITUICÃO POLITICA DO IMPERIO DO BRAZIL (de 25 de março de 1824. Disponível em: <http://www.planalto.gov.br/Ccivil_03/Constituiçao/Constituiçao24.htm>. CONSTITUIÇÃO DA REPÚBLICA DOS ESTADOS UNIDOS DO BRASIL (de 24 de fevereiro de 1891). Disponível em: <http://www.planalto.gov.br/Ccivil_03/Constituicao/Constituiçao91.htm>. Acesso em: 02 jan. 2009.

CONSTITUTION FINDER. UNIVERSITY OF RICHMOND. Disponível em: $<$ http://confinder.richmond.edu/country.php $>$.

CONSTITUTION OF JAPAN. Disponível em: $<$ http://www.solon.org.Constitutions/Japan/English/english-Constitution.html>. Acesso em 25 jan. 2009.

CONSTITUTION OF THE PEOPLE'S REPUBLIC OF CHINA. Disponível em: <http://www.usconstitution.net/china.html\#Article63>. Acesso em: 16 jan. 2009.

THE CONSTITUTION OF THE STATE OF ALASKA. Disponível em: <http://www.alaska.edu/creatingalaska/constitution>. Acesso em: 28 jan. 2008.

CONSTITUTION OF THE STATE OF GEORGIA. Disponível em: <http://sos.georgia.gov/ELECTIONS/constitution_2007.pdf>. Acesso em: $18 \mathrm{dez} .2008$.

CONSTITUTION OF THE STATE OF RHODE ISLAND AND PROVIDENCE PLANTATIONS. Disponível em: <http://www.rilin.state.ri.us/RIConstitution/C04.html>. Acesso em: 18 dez. 2008.

ETHIOPIAN CONSTITUTION Disponível em: $<$ http://www.sas.upenn.edu/African_Studies/Hornet/Ethiopian_Constitution.html>. Acesso em: 25 jan. 2009.

FINLAW.

Disponível

em:

$<$ http://fl1.findlaw.com/news.findlaw.com/hdocs/docs/electionspartnoyshlly072903opn.pdf>. Acesso em: 16 dez. 2008.

GEORGIA Law. Disponível em: <http://law.jstia.com/georgia/codes/21/21-4-3htm/>. Acesso em: 18 dez. 2008.

KANSAS Legislature. Disponível em: <http://www.kslegislature.org/legsrvstatutes/getStatuteFile.do?number=/25-4302.html>. Acesso em: 18 dez. 2008. 
LEY n. 741 de 2002 (COLOMBIA). Disponível em: <http://www.secretariasenado.gov.co/senado/basedoc/ley/2002/ley_0741_2002.html>. Acesso em: 25 jan. 2009.

MAGNA Carta is one of the most celebrated documents in history. Examine the British Library's copy close-up, translate it into English, hear what our curator says about it, and explore a timeline. Disponível em: <http://www.bl.uk/treasures/magnacarta/index.html\#>. Acesso em: 05 jan. 2009.

MINNESOTA CONSTITUTION. Article VIII. Impeachment and Removal from Office. Disponível em: <http://www.house.leg.state.mn.us/cco/rules/mncon/Article8.htm>. Acesso em: 18 dez. 2008; 16 jan. 2009.

MINNESOTA House of Representatives. Disponível em: <http://www.house.leg.state.mn.us/cco/rules/mncon.htm>. Acesso em 17 jan. 2009.

MONTANA CODE ANNOTATED - 2007. Disponível em: <http://data.opi.mt.gov/bills/mca/2/16/2-16-603.htm>. Acesso em: $18 \mathrm{dez} .2008$

NAÇÕES UNIDAS. Declaração dos Direitos Humanos. Disponível em: <http://www.onubrasil.org.br/documentos_direitoshumanos.php>. Acesso em: 16 jan. 2009.

NATIONAL CONFERENCE OF STATES LEGISLATURE. Disponível em: $<$ http://www.ncsl.org/programs/legman/elect/recallprovision>.

OFFICIAL California Legislative Information. Disponível em: <http://www.leginfo.ca.gov/cgi-bin/waisgate>. Acesso em: 22 dez. 2008.

PORTAL do Governo. Disponível em: <http://www.portugal.gov.pt/Portal/PT/Portal/PT/Portugal/Sistema_Politico/Constituiçao/c onstituiçãop13.htm>. Acesso em 16 jan. 2009.

PRESIDENNCIA DA REPÚBLICA. Disponível em: $<$ Www.planalto.gov.br/ccivil/Constituicao/Emendas/Emc_anterior1988?emc01_69.htm>. Acesso em: 09 jan. 2009.

PROGRAMA DAS NAÇÕES UNIDAS PARA O DESENVOLVIMENTO - PNUD. Disponível em: <http://ww.pnud.org.br>.

RECALL of State Elected Officials. A Proposed Minnesota Constitutional Amendment. Disponível em: <http://www.house.leg.state.mn.us/hrd/pubs/recall96.pdf>. Acesso em: 16 jan. 2009. 
RECALL of State Officials. National Conference of State Legislatures - The Forum for America's Ideas. Disponível em: $<\mathrm{http} / / /$ www.ncsl.org/programs/legismgt/elect/recallprovision.htm>. Acesso em: $18 \mathrm{dez}$. 2008; 17 e 26 jan. 2009.

REPUBLICA DE BOLIVIA. Corte Nacional Electoral. Disponível em: $<$ http://www.cne.org.bo/prces_electoral/Revocatorio2008/documentos/leyconvocatoria.pdf>. Acesso em: 19 dez. 2008.

REPUBLICA DEL COLÔMBIA. Secretaria del Senado. Disponível em: <http://www.secretariasenado.gov.co/leyes/CONS_P91.htm>. Acesso em: 18 dez. 2008.

SECRETARIA DE AMBIENTE Y DESAROLLO SUSTENTABLE DE LA NACIÓN. Disponível em: $<$ http://www.ambiente.gov.ar/archivos/web/biblioteca/File/Constituciones/cp_cordoba.pdf $>$. Acesso em: 18 dez. 2008.

SENADO FEDERAL. Disponível em: <Disponível em $<$ http://www.senado.gov.br/sf/publicacoes/diarios/pdf/sf/2005/12/09122005/43632.pdf>. Acesso em: 13 jan. 2009.

SUPREMO TRIBUNAL FEDERAL. Disponível em: $<$ http://www.stf.jus.br/portal/jurisprudencia/visualizarEmenta.asp?s1=000369043\&base=b aseAcordaos>. Acesso em: 10 jan. 2009.

TRIBUNAL SUPERIOR ELEITORAL. Disponível em: $<$ http://www.tse.gov.br/internet/index.html>. Acesso em: 30 dez. 2008.

TRIBUNAL SUPERIOR ELEITORAL Resolução $\mathrm{n}^{\circ}$ 22.610. Disponível em: $<$ http://www.tse.gov.br/internet/partidos/fidelidade_partidaria/res22610.pdf $>$. Acesso em: $30 \mathrm{dez} .2008$.

UC BERKELY. Institute of Governamental Studies. Disponível em: <http://igs.berkeley.edu/library/htrecall2003.html>. Acesso em: 22 dez. 2008.

UNIVERSITY OF ALASKA. Disponível em: <http://www.alska.edu>. www.alaska.edu/ WASHINGTON STATE CONSTITUTION. Disponível em: <http://www.leg.wa.gov/LawsAndAgencyRules/constitution.html>. Acesso em: $18 \mathrm{dez}$. 2008.

WASHINGTON STATE LEGISLATURE. Disponível em: <http://www.leg.wa.gov>. 